\title{
Role of iron in the accumulation of glomalin, an arbuscular mycorrhizal fungal glycoprotein
}

\author{
Kristine Ann Nichols \\ West Virginia University
}

Follow this and additional works at: https://researchrepository.wvu.edu/etd

\section{Recommended Citation}

Nichols, Kristine Ann, "Role of iron in the accumulation of glomalin, an arbuscular mycorrhizal fungal glycoprotein" (1999). Graduate Theses, Dissertations, and Problem Reports. 1025.

https://researchrepository.wvu.edu/etd/1025

This Thesis is protected by copyright and/or related rights. It has been brought to you by the The Research Repository @ WVU with permission from the rights-holder(s). You are free to use this Thesis in any way that is permitted by the copyright and related rights legislation that applies to your use. For other uses you must obtain permission from the rights-holder(s) directly, unless additional rights are indicated by a Creative Commons license in the record and/ or on the work itself. This Thesis has been accepted for inclusion in WVU Graduate Theses, Dissertations, and Problem Reports collection by an authorized administrator of The Research Repository @ WVU. For more information, please contact researchrepository@mail.wvu.edu. 


\title{
ROLE OF IRON IN THE ACCUMULATION OF GLOMALIN, AN ARBUSCULAR MYCORRHIZAL FUNGAL GLYCOPROTEIN
}

\author{
Kristine Ann Nichols \\ Master's Thesis submitted to the \\ College of Agriculture, Forestry and Consumer Sciences of \\ West Virginia University \\ in partial fulfillment of the \\ requirements for the degree of \\ Master of Science \\ in \\ Environmental Microbiology \\ Joseph Morton, Chair \\ Devinder Bhumbla \\ Daniel Panaccione \\ Sara Wright \\ Morgantown, West Virginia \\ 1999
}

Keywords: Arbuscular Mycorrhizal Fungi, Glomalin, Glycoprotein, Iron, Chelation 


\title{
ROLE OF IRON IN THE ACCUMULATION OF GLOMALIN, AN ARBUSCULAR MYCORRHIZAL FUNGAL GLYCOPROTEIN
}

\author{
Kristine Ann Nichols
}

\begin{abstract}
(ABSTRACT)
Effects of iron on production of glomalin, an arbuscular mycorrhizal fungal glycoprotein, were examined. In a preliminary experiment comparing available (FeEDDHA) and unavailable iron (hematite), low amounts of glomalin were produced with the former while the latter total inhibited the symbiosis. Part of the effect of hematite was reduced spore germination. A glycoprotein cross-reacting with a monoclonal antibody against glomalin was produced in nonmycorrhizal pots. This molecule is similar to glomalin, but has some unique characteristics. Concentration increases when $\mathrm{C} 3$ and $\mathrm{C} 4$ grasses are stressed from low nutrients and/or light but levels are at least 10-fold less than glomalin. Two chelated iron sources, FeEDDHA and FeEDTA, at three concentrations resulted in glomalin accumulation at least $75 \%$ lower than normal resulting from environmental limitations. Glomalin concentration was independent of fungal biomass and iron source. To better test this interaction in the future, more optimum environmental conditions for plant growth are needed.
\end{abstract}




\section{ACKNOWLEDGEMENTS}

I would like to thank my advisor Dr. Joseph Morton for his support, advice, guidance, and friendship. I would also like to give a special thank you to Dr. Sara Wright, who discovered this challenging and amazing protein and who is continuing to support my glomalin explorations. In addition, I owe a great deal to the other two members of my committee, Dr. Devinder Bhumbla and Dr. Daniel Panaccione, who offered advice, help, and encouragement.

I thank all the faculty and staff members of the Plant Pathology and Environmental Microbiology Department (both past and present), who helped me in countless ways. A special thank you to Bill Wheeler, Beth Thomas, Sidney Stürmer, Kelly Fleming, and various student workers for their research help and advice. My thanks to Dr. Larry Douglass and Dr. Gerald Hobbs for their statistical help and advice, to Joan Wright and Harjinder Sandu for their help with the foliar tissue assays, and to US Silica, Inc. for donating the fine sand. I would also like to recognize some people at USDA-ARS, who have helped a lot in the writing of this thesis, namely my office mates (Linda Jawson, Mark Davis, and Stanley Tesch) and my comrade-inarms, David Ingram. These people have put up with my crazy hours and various other problems that come with writing. In addition, I want to thank West Virginia University for its financial support and USDA-ARS for some of the facilities and equipment that I used in completing my research. With that I would like to acknowledge Dr. Sara Wright for her help and encouragement, for putting up with my schedule, for her continued financial support.

I would like to acknowledge Dr. Iris Charvat, at the University of Minnesota, who started my mycorrhizal obsession. Many of the best things that have ever happened to me have happened out of accident, and meeting and working with Dr. Charvat is at the top of that list. Also, at the top of that list are all of the extraordinary people that I have met, worked with and lived with in Minnesota, West Virginia, and Maryland. I owe this fantastic journey, my survival and, more importantly, my sanity to all of you. So, thank you for your help, support, love, and for putting up with me and all the times that I promised that I would be right there but showed up an hour+ later.

Finally, I would like to thank my family for all of their love, support, encouragement, and understanding as I moved further and further away from my home, but came closer and closer to my roots. I would like to acknowledge my parents James, Joyce, and Linda, for my being here, both physically and mentally, and my siblings Eric, Tami, and Penni, who helped make me the person I am. I also owe a great deal of thanks to the strong women in my family, who have been a great example, especially my grand aunts, Maxine and Elizabeth Nichols. Aunt Betty told me that she discovered when writing her thesis that 'Knowledge makes a painful entry', and I, too, now know exactly what she meant. 


\section{TABLE OF CONTENTS}

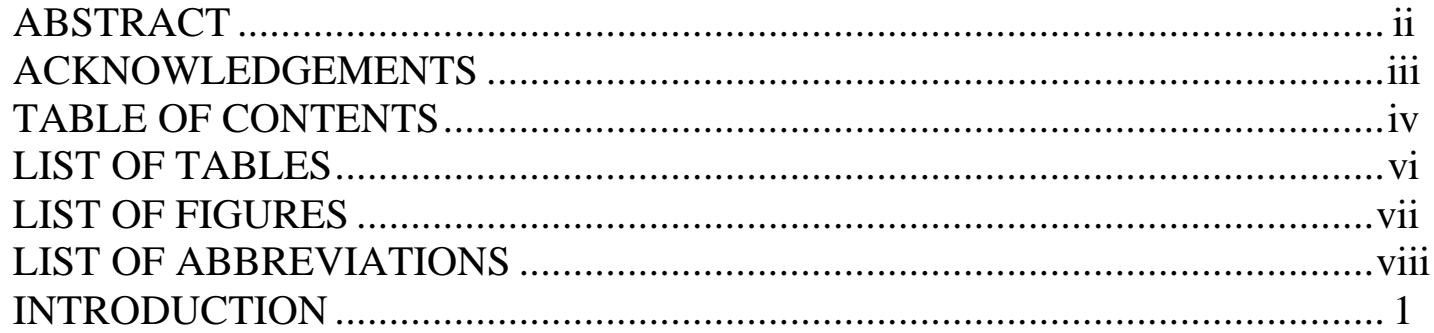

Chapter 1 - Effects of hematite (Fe2O3) on spore germination of two arbuscular mycorrhizal fungal species, Gigaspora gigantea and

Glomus etunicatum ................................................................................... 5

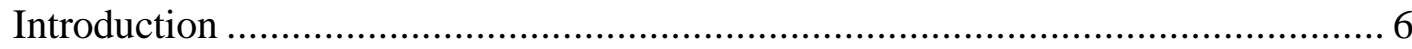

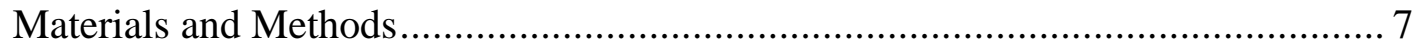

Preparation of spore germination media ....................................................... 7

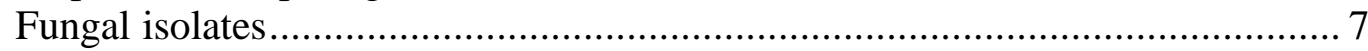

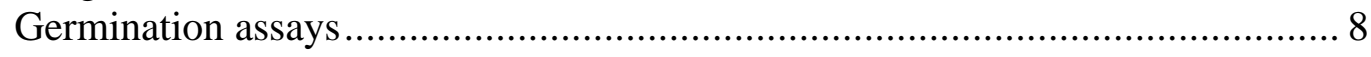

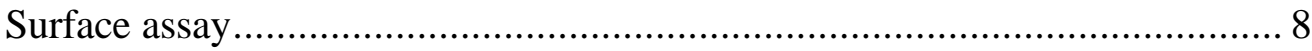

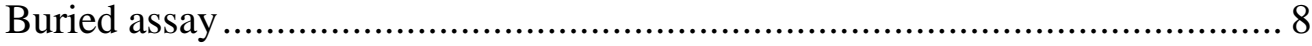

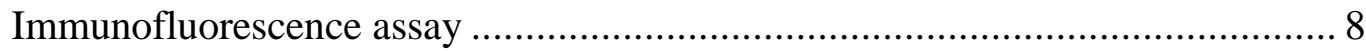

Spore counts and statistical analysis................................................... 9

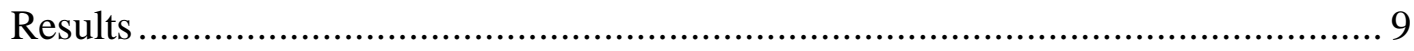

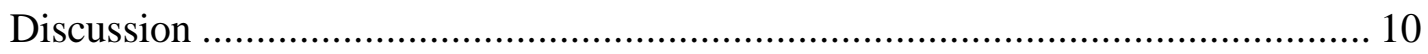

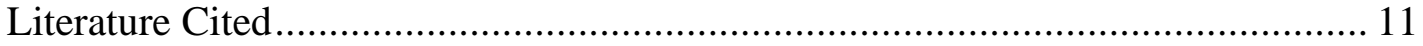

Chapter 2 - A glycoprotein produced by nonmycorrhizal plants that is cross-reactive with a monoclonal antibody against glomalin....................... 21

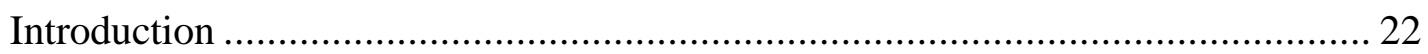

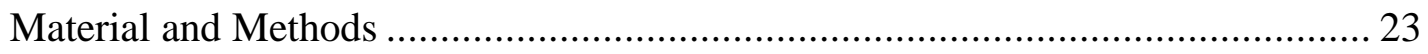

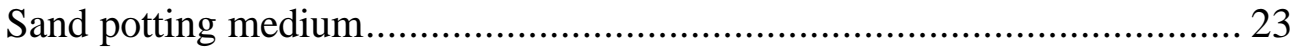

Amendments to potting medium ......................................................... 23

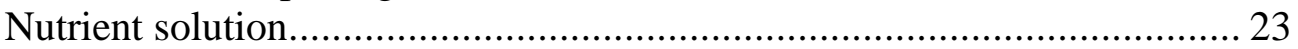

Growth room conditions ................................................................ 23

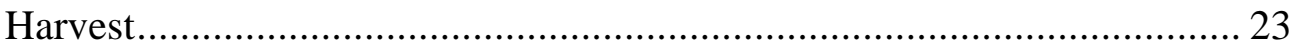

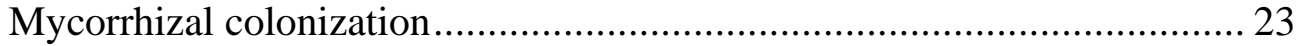

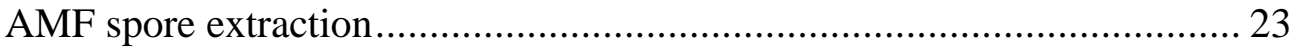

Protein extraction and concentration measurement .................................. 23

Experiment 1-Glycoprotein accumulation by nonmycorrhizal sorghum ............ 24

Experiment 2-Verification of absence of AMF contamination in

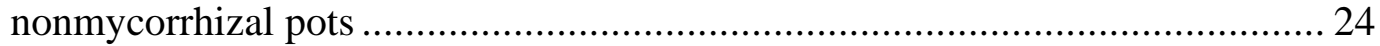

Immunoreactivity of roots and hyphae separately ................................ 25

Experiment 3-Glycoprotein accumulation by nonmycorrhizal C3 and

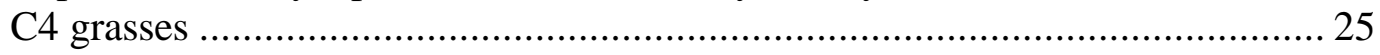

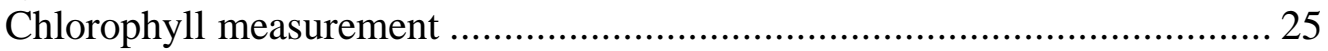




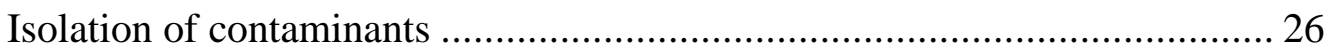

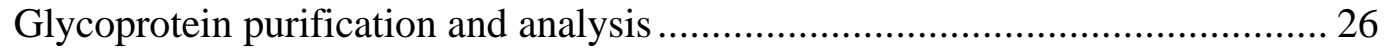

Immuno-dot blot assay of nonmycorrhizal extracts.................................... 26

Protein purification and lyophilization......................................................... 26

Glycoprotein carbohydrate confirmation of lyophilized extract ..................... 27

SDS-PAGE gel of extracts from the two grasses............................................ 27

Immunofluorescence assay of nonmycorrhizal roots and hyphae ................... 27

Microwave digestion and iron analysis of lyophilized protein........................ 27

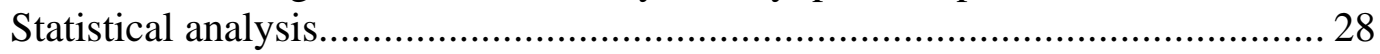

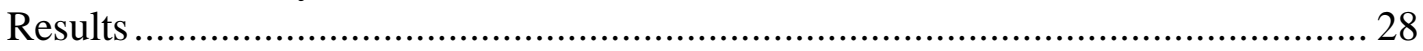

Tests for contamination and nonspecific binding.......................................... 28

Characterization of the nonmycorrhizal glycoprotein ...................................... 28

Glycoprotein accumulation by nonmycorrhizal sorghum................................... 29

Glycoprotein accumulation in nonmycorrhizal pots used to verify the

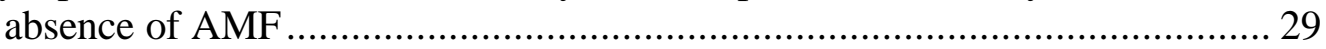

Glycoprotein concentrations in two nonmycorrhizal grasses ............................. 29

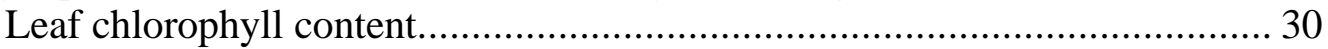

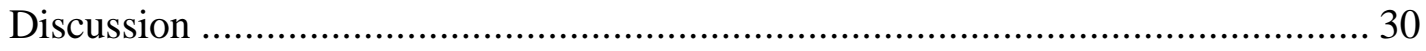

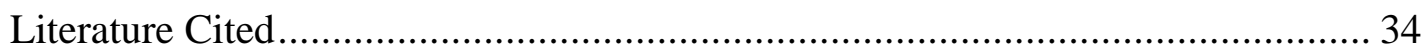

Chapter 3 - Effects of two chelated iron sources on the accumulation of glycoprotein in mycorrhizal and nonmycorrhizal sudangrass......................... 47

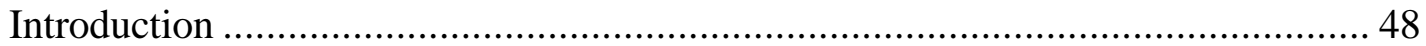

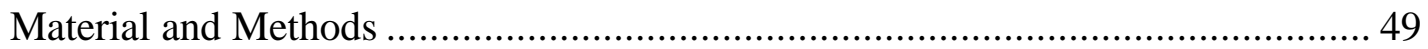

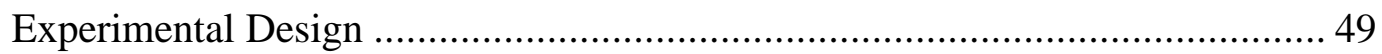

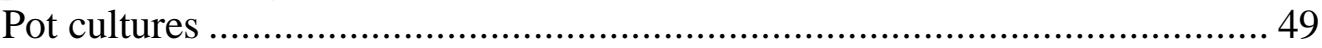

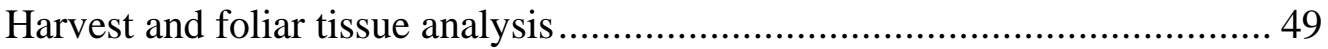

Glycoprotein extraction from various pot media fractions............................. 50

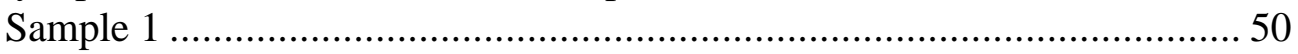

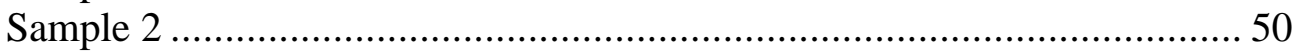

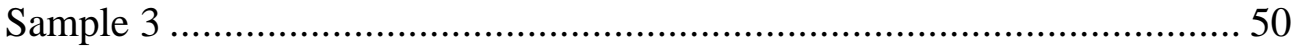

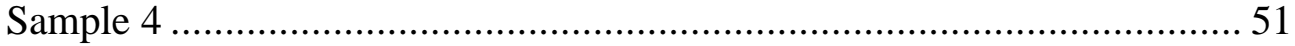

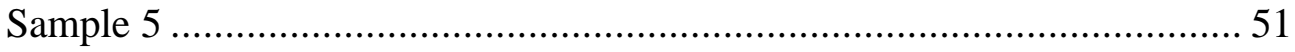

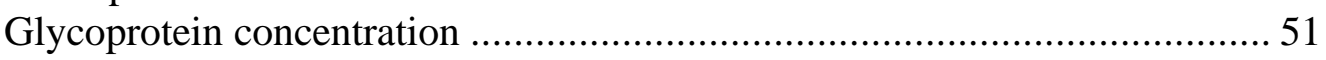

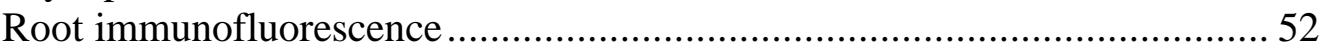

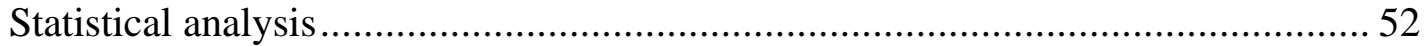

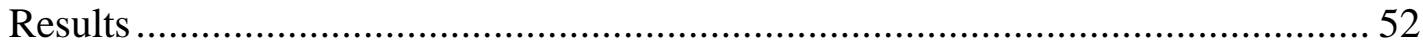

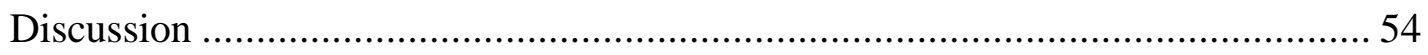

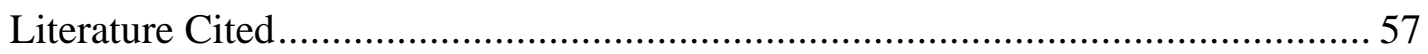

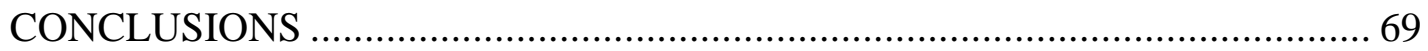

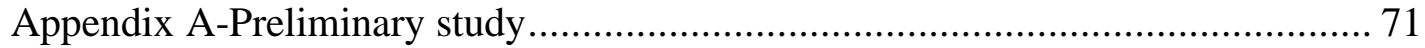

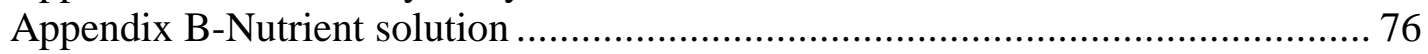

Appendix C-Glycoprotein carbohydrate estimation ............................................. 78

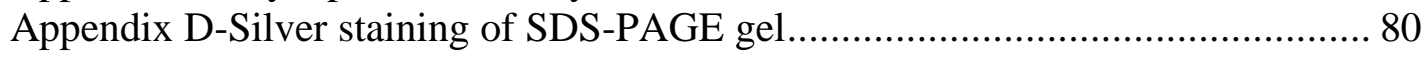

Appendix E-Microwave program for foliar tissue digestion.................................. 82

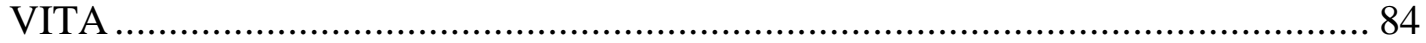




\section{LIST OF TABLES}

Chapter 2

Page

1 Percentage iron in the cross-reactive glycoprotein molecule

2 Immunoreactive glycoprotein in a potting media/root subsample from nonmycorrhizal sorghum.

3 Effects of $\mathrm{pH}$ and iron levels on concentration of an immunoreactive glycoprotein extracted from potting medium of nonmycorrhizal sorghum.

4 Chlorophyll a and b concentration in foliar tissue of nonmycorrhizal sorghum and fescue.

5 Immunoreactive and total protein concentration of nonmycorrhizal sorghum and fescue.

6 Strongly correlated interactions for nonmycorrhizal sorghum and fescue.

\section{Chapter 3}

$1 \quad$ Foliar tissue analysis (mean $\pm \mathrm{SE}$ ) of mycorrhizal and nonmycorrhizal sudangrass treated with different concentrations of FeEDTA and FeEDDHA.

2 Percentage mycorrhizal colonization and fungal sporulation within (sand:soil mix) and outside (sand) of the mesh bag ....

3 Glomalin and nonmycorrhizal glycoprotein concentrations (mean \pm $\mathrm{SE}$ ) on various sieved fractions containing roots and/or fungal material.

4 Glomalin and nonmycorrhizal glycoprotein concentration $(\mu \mathrm{g} / \mathrm{g})$

(mean $\pm \mathrm{SE}$ ) on sieved sand:soil or sand fractions

5 Glomalin and nonmycorrhizal glycoprotein concentration $(\mu \mathrm{g} / \mathrm{g})$ (mean \pm SE) for subsamples taken directly (i.e. without sieving).

6 Comparison of mycorrhizal to nonmycorrhizal sudangrass plants for foliar tissue analyses, percentage mycorrhizal colonization, sporulation, and protein measurements. 


\section{LIST OF FIGURES}

\section{Chapter 1}

$1 \quad$ Extracted dead spores can easily be distinguished from live spores

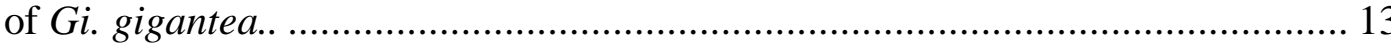

2 Germinating spore of Gi. gigantea and G. etunicatum ................................. 14

3 Spore germination on a nylon membrane on the surface of or buried in a sterile sand or hematite amended sand.

4 Surface germination assay: Percentage germination and mortality of Gi.gigantea (MA453A) spores exposed to three iron oxide treatments: $0 \mathrm{Fe}, 0.5 \%$ hematite, and $1.5 \%$ hematite

$5 \quad$ Surface germination assay: Percentage germination and mortality of Gi.gigantea (PA125) sporesexposed to three iron oxide treatments: $0 \mathrm{Fe}, 0.5 \%$ hematite, and $1.5 \%$ hematite

6 Surface germination assay: Percentage germination of $G$. etunicatum (BR200 and NE108A) spores after 14 and 28 days exposed to two iron oxide treatments: $0 \mathrm{Fe}$ and $1.5 \%$ hematite

$7 \quad$ Buried germination assay: Percentage germination and mortality for spores of Gi gigantea (MA453A) after 14 days buried in pots with three iron oxide treatments: $0 \mathrm{Fe}, 0.5 \%$ hematite, and $1.5 \%$ hematite

8 Buried germination assay: Percentage germination of Gi gigantea (NE108A) spores in pots after 32 days buried in three iron oxide treatments: $0 \mathrm{Fe}, 0.5 \%$ hematite, and $1.5 \%$ hematite

\section{Chapter 2}

1 SDS-PAGE gels using PhastSystem

2 Immuno-dot blot assays of glomalin and glycoprotein from nonmycorrhizal pots untreated or boiled in 3\% SDS for $10 \mathrm{~min}$

3 Immunofluorescence on roots of tall fescue at 10x and $40 \mathrm{x}$ after incubation with MAb 32B11.

\section{Chapter 3}

1 Stages in pot culture setup.

2 Comparisons between mycorrhizal and nonmycorrhizal sudangrass.

3 Patchy immunofluorescence of glomalin-like glycoprotein on nonmycorrhizal sudangrass roots...

4 Immunofluorescent glomalin selectively coating hyphae of

Gigaspora gigantea. 


\section{LIST OF ABBREVIATIONS}

$\underline{\text { Abbreviation }}$

$\mathrm{hr}$

$\mathrm{s}$

$\min$

$\mathrm{g}$

$\mathrm{L}$

$\mathrm{ml}$

$\mu 1$

$\mu \mathrm{g}$

$\mathrm{cm}$

$\mathrm{mm}$

$\mathrm{v}$

$\mathrm{mA}$

$\mathrm{C}$

$\mathrm{N}$

$\mathrm{M}$

$\mathrm{mM}$

$\mu \mathrm{M}$

$\mathrm{Fe}$

$\mathrm{P}$

$\mathrm{Ca}$

$\mathrm{Zn}$

$\mathrm{Al}$ $\underline{\text { units }}$

hour(s)

second(s)

minute(s)

$\operatorname{gram}(\mathrm{s})$

liter(s)

milliliter(s)

microliter(s)

microgram(s)

centimeter(s)

millimeter(s)

volts

milliamps

Celsius

normal

molar

millimolar

micromolar

iron

phosphorus

calcium

zinc

aluminum 


\section{INTRODUCTION}

Nutrients are cycled in the soil environment through the interactions of biological, physical, and chemical components. The rhizosphere, or root zone, is the location of the greatest flow of energy and minerals among these components (Wright and Millner, 1994). In this highly productive region, a vital symbiosis exists between roots of $80 \%$ of all vascular plant species and soil-borne arbuscular mycorrhizal fungi (AMF) (Trappe, 1987). This mutualistic association appears to have co-evolved for more than 400 million years (Morton, 1990; Simon et al., 1993; Taylor et al., 1995) with plants benefitting from uptake of immobile nutrients in soil and improved soil structure (Wright and Uppadhyaya, 1998) and the fungus obtaining carbon and other essential nutrients from the host (Smith and Read, 1997). Intracellular arbuscules formed by AMF are thought to be the primary site where nutrient exchange occurs. Extramatrical hyphae establish the bridge for nutrient uptake and translocation to the plant.

AMF utilize simple carbohydrates, typically between $12-27 \%$ of the photoassimilated carbon. The host, in turn, gains nutrients, water, increased tolerance to opportunistic pathogens, and various other benefits (Wright and Millner, 1994). The greater acquisition of immobilized nutrients in soil, such as $\mathrm{P}, \mathrm{Fe}, \mathrm{Cu}$, and $\mathrm{Zn}$, is the result of exploration of microsites by extramatrical hyphae as well as increased nutrient use efficiency of mycorrhizal roots. The intimacy of this symbiosis indicates that host and fungal genotypes and soil abiotic and biotic variables can greatly influence its nature (Brundrett, 1991).

The extramatrical hyphae of all AMF tested to date are coated with a surface glycoprotein named glomalin (Wright et al., 1996). As hyphae degrade, this hydrophobic, highly stable glycoprotein sloughs off to coat soil organic matter and other soil particles. As a result, Wright and Upadhyaya (1998) found a strong correlation between glomalin concentration and soil aggregation. Glomalin has been found in a wide range of soil environments (acid, calcareous, grassland, and cropland soils) in quantities ranging from 4.4 to $14.4 \mathrm{mg}$ of protein per $\mathrm{g}$ of soil (Wright and Upadhyaya, 1996). Because of its apparent ubiquity, glomalin is thought to play important roles both in the symbiotic association and in altering soil structure. Much remains to be learned about the chemical structure and activity of glomalin, but results thus far clearly establish that the macromolecule is a glycoprotein with a high lectin binding ability, heat resistance and persistance in soil. Wright et al. (1996) hypothesize that glomalin forms a conglomeration with root fragments and organic matter, thus protecting it from degradation by microorganisms.

Because of its dark reddish-orange color and the denudation of the soil after protein extraction in heated citrate buffer, iron was hypothesized to be an important structural component of glomalin (Wright and Upadhyaya, 1998). Following microwave digestion, atomic absorption analysis indicates that the amount of iron in the molecule varies from $0.8-8.8 \%$ (Wright and Upadhyaya, 1998). These researchers hyphothesize that the iron component may play a role in glomalin accumulation and/or function, because cultures grown in media that contains low levels of iron had little glycoprotein accumulation and one AMF isolate, Gigaspora gigantea (MA453A), failed to grow under these Fe-limited conditions. These results are corroborated by field surveys in which the concentration of glomalin is low in high $\mathrm{pH}$ soils, where iron is less available (Wright and Upadhyaya, 1998). No information has yet been 
obtained as to how AMF acquire iron from the soil, what types of iron are available to the fungus, and the dynamics of glomalin accumulation on external hyphae, auxiliary cells, spores, or internal structures (intraradical hyphae, arbuscules, vesicles).

The correlation between glomalin concentration and soil aggregation also may be influenced by iron because materials bound by polyvalent metal cations and polymers contribute to the persistence of aggregates (Wright and Upadhyaya, 1998). Kemper and Chepil (1965) found that aggregate stability is a function of organic matter, clay and free iron oxides. Iron deficiency may result in low aggregation and low glomalin, as has been found in calcareous soils of Texas (Wright and Upadhyaya, 1998).

The role of iron in glomalin structure and function can be inferred initially from an analysis of the environments of terrestrial plants and their fungal associates during their 400 million years of coevolution. Recent evidence of similar sequences in the SSU rRNA region between several Glomus species and Geosiphon pyriforme begins to shed new light on the origin of AMF lineages (Gehrig et al., 1996). Geosiphon pyriforme is the host for cyanobacterium, Nostoc puntiforme, and forms a structure for nutrient exchange analagous to the arbuscule of AMF (Gehrig et al., 1996). This endosymbiosis has two important implications for glomalin and its iron component. First, G. pyriforme is related to the oldest of AMF lineage, the genus Glomus (Simon et al., 1993; Taylor et al., 1995). Second, Nostoc is a nitrogen-fixing autotroph, and both nitrogen fixation and photosynthesis have a high iron requirement. As a result, autotrophic Nostoc and heterotrophic Geosiphon may have evolved glomalin or a glycoprotein progenitor to acquire iron, especially in an aquatic environment where this cation would be limiting.

The mycorrhizal symbiosis that subsequently evolved optimizes Liebig's "Law of the Minimum". This is because the fungus obtains carbon that the plant has in abundance and the plant acquires soil minerals accessible to fungal hyphae (Read, 1991). When plants first colonized land, the environment was very harsh with few plant-available nutrients and little structure to the soil (Lewis, 1987). Weathering of silicates in an abiotic environment was very slow, due mostly to mechanical and chemical weathering, which in turn were hampered by rapid wind and rain erosion in the absence of crust stabilizing algae, lichens, and more advanced biota (Schwartzman and Volk, 1989). Devonian land plants were very simple morphologically, with few leaves, branches, or roots. Evolutionary progress was expressed in variant genotypes with greater nutrient-extraction ability and habits promoting water retention (Pirozynski and Malloch, 1975; Schwartzman and Volk, 1989; Talyor et al., 1995). Plants did not readily evolve root hairs to improve efficiency of adsorption. Instead, they exploited their relationship with organisms, such as fungi, algae, to combat nutrient deprivation (Pirozynski and Malloch, 1975; Taylor et al., 1995).

Algae and fungi have been implicated in the formation of calcareous crusts and biomineralization that make nutrients plant available (Stubblefield and Taylor, 1988). The mycorrhizal symbiosis and the glomalin byproduct would increase the rate of soil development (via aggregation). This, in turn, would lower $\mathrm{P}_{\mathrm{CO} 2}$ and surface temperatures for the evolution of more complex lifeforms (Schwartzman and Volk, 1989). In addition, iron accumulation in the form of glomain may provide iron needed for enzymes in photosynthesis. 
Ecological, geological, and cytological evidence has shown that there were explosive periods of morphological innovation during the Devonian Period. During this time, photosynthetic free oxygen became more abundant, allowing plants to colonize land by protecting them from UV radiation (Pirozynski and Malloch, 1975). The number of genera of plants increased from 1 to 28, plants changed from tiny creeping structures to a diverse array of tiny to 0.5-9 m high structures, and morphological features also evolved, such as leaves, roots, reproductive systems, and secondary growth (Gensel and Andrews, 1987). As protected root inhabitants, endomycorrhizal fungi have changed little from their ancient relatives, because they have not been subjected to the selective pressures that have caused morphological changes among the plants (Lewis, 1987; Morton, 1990; Stubblefield and Taylor, 1988). Glomalin, either because of a neutral to net positive benefit over time, also appears to have been conserved, as evidenced by its ubiquity in taxa of all glomalean lineages. Its absence among other fungal lineages also suggests that the glycoprotein evolved uniquely as a result of the symbiosis.

As a result of this history, the role of iron in glomalin formation and function requires further elucidation. In this thesis, I determine how plant-availabe iron affected glomalin accumulation. I also examine the effect of iron oxide (hematite), an unavailable iron source, on germination of AMF spores. In the course of my studies, I detected glycoprotein production in nonmycorrhizal pot cultures, and so I elucidate its serological affinities with glomalin and the extent to which it is produced by different plant species.

\section{LITERATURE CITED}

Brundrett, M. 1991. Mycorrhizas in Natural Ecoystems. Advances in Ecological Research 2:171-220.

Gehrig, H., A. Schubler, and M. Kluge. 1996. Geosiphon pyriforme, a fungus forming endocytobiosis with Nostoc (Cyanobacteria), is an ancestral member of the Glomales: Evidence by SSU rRNA analysis. Journal of Molecular Evolution 43:71-81.

Gensel, P.G. and H.N. Andrew. 1987. The evolution of early land plants. American Scientist 75:478-489.

Lewis, D.H. 1987. Evolutionary aspects of mutualistic associations between fungi and photosynthetic organisms. In: Evolutionary Biology of the Fungi. A.D.M. Rayner, D.M. Brasier and D. Moore, Eds. Cambridge University Press, Cambridge.

Kemper. W.D. and W.S. Chepil. 1965. Size distribution of aggregates. In Methods of soil analysis, Part I. Ed: C.A. Black. Agronomy No. 9. American Society of Agronomy 499509.

Morton, J.B. 1990. Species and clones of arbuscular mycorrhizal fungi (Glomales, Zygomycetes): Their role in macro- and microevolutionary processes. Mycotaxon 37:493-515.

Pirozynski, K.A. and D.W. Malloch. 1975. The origin of land plants: A matter of mycotrophism. BioSystems 6:153-164.

Read, D.J. 1991. Mycorrhizas in ecosystems-Nature's response to the "Law of the Minimum". Frontiers in Mycology. Ed. D.L. Hawksworth. CAB International.

Schwartzman, D.W. and T. Volk. 1989. Biotic enhancement of weathering and the habitability of Earth. Nature 340:457-460. 
Simon, L., J. Bousquet, R.C. Levesque, and M. Lalonde. 1993. Origin and diversification of endomycorrhizal fungi and coincidence with vascular land plants. Nature 363:67-69

Smith, S.E. and D.J. Read. 1997. Mycorrhizal symbiosis, $2^{\text {nd }}$ Edition. Academic Press: Sand Diego.

Stubblefield, S.P. and T.N. Taylor. 1988. Tansley review no. 12: Recent advances in paleomycology. New Phytologist 108:3-25.

Taylor, T.N., W. Remy, H. Haas, and H. Kerp. 1995. Fossil arbuscular mycorrhizae from the Early Devonian. Mycologia 87:560-573.

Tommerup, I.C. 1982. Airstream fractionation of vesicular-arbuscular mycorrhizal fungi: Concentration and enumeration of propagules. Applied Environmental Microbiology 44:533-539.

Trappe, J.M. 1987. Phylogenetic and ecological aspects of mycotrophy in the angiosperms from an evolutionary standpoint. In: Ecophysiology of VA Mycorrhizal Plants. Ed. G.R. Safir. CRC Press: Boca Raton, Florida. 5-25.

Wright, S.F. and P.D. Millner. 1994. Dynamic processes of vesicular-arbuscular mycorrhizae: A mycorrhizosystem within the agroecosystem. In: Advances in Soil Science. Soil Biology: Effects on Soil Quality. Eds. J.L. Hatfeld and B.A. Stewart. Lewis Publishers. Boca Raton, FL, USA. 29-59.

Wright, S.F., M. Franke-Snyder, J.B. Morton, and A. Upadhyaya. 1996. Time-course study and partial characterization of a protein on arbuscular mycorrhizal hyphae during active colonization of roots. Plant and Soil 181:193-203.

Wright, S.F. and A. Upadhyaya. 1996. Extraction of an abundant and unusual protein from soil and comparison with hyphal protein of arbuscular mycorrhizal fungi. Soil Science $161: 1-12$.

Wright, S.F., and A. Upadhyaya. 1998. A survey of soils for aggregate stability and glomalin, a glycoprotein produced by hyphae of arbuscular mycorrhizal fungi. Plant and Soil 198:97-107. 


\section{CHAPTER ONE}

\section{EFFECTS OF HEMATITE $\left(\mathrm{Fe}_{2} \mathrm{O}_{3}\right)$ ON SPORE GERMINATION OF TWO ARBUSCULAR MYCORRHIZAL FUNGAL SPECIES, GIGASPORA GIGANTEA AND GLOMUS ETUNICATUM}




\section{INTRODUCTION}

Arbuscular mycorrhizal fungi (AMF) are important mutualistic symbionts in a variety of ecosystems that improve the health and diversity of plant life (Brundrett, 1991). Plants give the fungus carbohydrates necessary for mycorrhizal development and sporulation, and the fungus absorbs and translocates nutrients and water in soil via an extensive network of extramatrical hyphae (Smith and Read, 1997). AMF reproduce via the formation of asexual spores allowing individuals to be transported beyond the growth of hyphae attached to a plant root and also for short-term survival in harsh or plant-deficient environments (Morton, 1990). Germination of these spores consists of four stages: (1) hydration of cellular proteins and colloids; (2) activation and formation of ribonucleic acids and enzymes; (3) the protrusion of a germ tube; and (4) growth of hyphae to roots of a mycotrophic host or death (Tommerup, 1984). Despite the inability of AMF to fulfill their life cycle in the absence of a host, germination can occur without host roots. Germination events therefore can be studied in axenic culture, where specific treatments may be applied and their individual effects measured.

As spores germinate, a germ tube extends into the soil and either penetrates a root upon contact to initiate mycorrhizal development or resources in the spore are depleted and death ensues. In some genera, namely Gigaspora and Scutellospora, spores are the sole viable propagules when detached from host roots (Morton and Benny, 1990; Safir, 1994). In contrast, all extraradical parts of fungi in Glomus, Acaulospora, or Entrophospora are potentially infective propagules (Biermann and Linderman, 1983).

Germination of AMF spores is affected by a variety of endogenous and exogenous factors, including $\mathrm{pH}$, temperature, water potential, nutrients, light, self-inhibitors, growth inhibitors, agricultural chemicals, and associated microorganisms (Sylvia and Schenck, 1983). Newly formed spores are innately dormant, and dormancy is alleviated by maturity, storage, time of collection, cultural history, or physiological changes rather than by the presence of growing plant roots (Tommerup, 1983). Koske (1981) observed germination of Gigaspora gigantea spores under a variety of conditions and found no difference in germination in response to the following factors: surface sterilization of spores; growth on agar, sterile sand, or non-sterile sand; growth with different phosphorus concentrations; or cold storage less than 6-8 months. Different temperature regimes, however, did effect germination. Germination was reduced when wet sieving was used to remove spores from soil, with the addition of glucose, or when the water potential was below 0 bars (Koske, 1981). Several researchers have found that water potential has a consistent effect on germination, and water potentials at or slightly greater than field capacity are recommended for increasing germination (Brundrett and Juniper; 1995, Koske, 1981; Siqueira et al., 1985; Sylvia and Schenck, 1983). Cold storage also appears to aid in synchronization of germination among groups of spores (Koske, 1981; Safir et al., 1980; Siqueira et al., 1985).

Other external factors impact spore germination, albeit less consistently. Absence of associated bacteria in axenic spore germination assays can inhibit germ tube formation (Mayo et al., 1986). Inorganic ions, such as $\mathrm{Mn}, \mathrm{Zn}, \mathrm{Cu}, \mathrm{Ca}$, and $\mathrm{Al}$ also can be inhibitory (Siqueira et al. 1985), although further studies with $\mathrm{Al}$ indicate differential positive or negative responses among fungal isolates (Bartolome-Estaban and Schenck, 1994). The $\mathrm{pH}$ of the environment surrounding 
spores also is an important factor in germination. Other spore germination assays indicated direct effects of soil pH. Isolates of Gigaspora and Acaulospora species have an acidic $\mathrm{pH}$ optimum, while those of Glomus species favor neutral to alkaline $\mathrm{pH}$ (Siquiera et al., 1985). Conditions required for spore germination of a given AM fungus may vary, and because internal mechanisms are not well understood and/or are difficult to measure in viable spores, mechanisms of inhibition of spore germination are difficult to pinpoint.

Glomalin, a name coined for a glycoprotein coating AMF external hyphae, also may play a role in spore germination (Wright et al, 1996). Iron appears to be a major component of this protein (Wright and Anderson, 1999) and may play a role in protein function. In a preliminary experiment to compare soluble and insoluble iron sources on glomalin accumulation on AMF hyphae, an insoluble iron oxide (hematite) completely suppressed mycorrhizal colonization (Appendix A). One possible explanation for this result was that hematite is toxic to AMF spores and prevents germination and mycorrhizal development. This study investigated the hyphotheis that hematite acted directly to suppress spore germination of isolates of the same AMF species used in the preliminary experiment.

\section{MATERIALS AND METHODS}

\section{Preparation of spore germination media}

The germination medium consisted of coarse ( $85 \%$ of sand collected on \#50 mesh or less) and fine (68\% collected on \#70 mesh or greater) silica sand mixed 2:1 (v/v), respectively. The sand mixture was washed three times with $2-3 \mathrm{~N} \mathrm{HCl}$ to remove residual iron followed by autoclaving at $121^{\circ} \mathrm{C}$ for $1 \mathrm{hr}$ with $50 \mathrm{mM}$ sodium citrate, $\mathrm{pH} 8.0$ to remove residual glomalin (Wright et al., 1996). After a thorough rinsing with distilled water, the sand was autoclaved again at $121^{\circ} \mathrm{C}$ for $40 \mathrm{~min}$ and air-dried. Three media were prepared: (i) sand alone; (ii) sand mixed with $0.5 \%(\mathrm{w} / \mathrm{w})$ hematite; and (iii) sand mixed with $1.5 \%(\mathrm{w} / \mathrm{w})$ hematite.

\section{Fungal isolates}

All spores were obtained from stored monospecific cultures of AMF maintained in the International Collection of Arbuscular and VA Mycorrhizal Fungi (INVAM) at West Virginia University (Morton et al., 1993). One species each of Gigaspora and Glomus were selected, since each genus differed greatly in mode of spore germination (Morton and Benny, 1990). Of Gigaspora species, Gi. gigantea was chosen because spore contents visibly change in color from bright yellow-green in the healthy state to dark orange-red with senescence and loss of viability (Fig. 1) and the germ tube is readily observable (Fig. 2A). The two INVAM accessions selected were MA453A and PA125. Glomus etunicatum was chosen because it is a widespread species that produces abundant germinable spores in culture, although size and location of the germ tube sometimes makes germination difficult to assess (Fig. 2B). Accessions NE108A and BR220 were selected for this study.

Spores were extracted from pot cultures that had been stored for 2-16 months at $4^{\circ} \mathrm{C}$. Fifty $\mathrm{cm}^{3}$ of culture soil were blended in water in three 10 second bursts and the resultant mix passed through nested sieves with 500 and $45 \mu \mathrm{m}$ openings. Material on the $45 \mu \mathrm{m}$ sieve was 
rinsed into a centrifuge tube containing a 20/60\% sucrose gradient and spun at $900 \mathrm{x} \mathrm{g}$ for $1 \mathrm{~min}$. Spores were decanted from centrifuge tubes, washed for 1-2 minutes and then transferred to a Petri dish. Spores that appeared healthy were selected with the aid of a stereomicroscope, rinsed with sterile water, and stored at $4^{\circ} \mathrm{C}$ for at least $24 \mathrm{hrs}$ to synchronize germination and to check for senescence or microbial growth.

\section{Germination assays}

Surface assay. Fifty $\mathrm{cm}^{3}$ of each of the three sand media were placed in sterile plastic Petri dishes and moistened with sterile distilled water. A circular piece of nylon mesh with 40 $\mu \mathrm{M}$ openings was placed atop the medium, and directly over this was placed a $0.45 \mu \mathrm{M}$ nylon membrane (Fig. 3A) (Brundrett and Juniper, 1995).

Individual spores from each separate accession were placed randomly on the nylon membrane with at least $40 \mathrm{Gi}$. gigantea spores or $60 \mathrm{G}$. etunicatum spores per membrane. Plates were wrapped with parafilm, covered with aluminum foil, and stored at room temperature. Spores were examined at two to three day intervals for up to 28 days under a stereomicroscope for germ tube formation, change in color, or physical changes such as plasmolysis of contents or collapse.

Buried assay. Each of the three sand media was placed in a $7.5 \mathrm{~cm}$ ID plastic pots. Spores of Gi. gigantea (MA453A) and G. etunicatum (NE108A) were extracted and processed as described above. Spores were placed on one side of a $0.45 \mu \mathrm{m}$ membrane with at least $20 \mathrm{Gi}$. gigantea and $30 \mathrm{G}$. etunicatum spores per membrane. Each membrane was folded into quarters and placed in $45 \mu \mathrm{M}$ nylon mesh bags (Fig. 3B). Bags then were buried $1 \mathrm{~cm}$ below the surface, with three bags per pot. Pots were stored in the dark at room temperature and watered as needed with sterile distilled water.

Pots containing Gi. gigantea and G. etunicatum spores were checked after 14 and 32 days, respectively. Membranes were removed from each nylon bag, flooded with $0.05 \%$ Direct Blue stain (w/v) in lactic acid, water and glycerol (1:1:1), and examined under a stereomicroscope for germ tube formation, changes in spore color, and changes in spore appearance.

\section{Immunofluorescence assay}

Deposition of glomalin on germination tubes was examined by immunofluorescence microscopy (Wright et al., 1996). Mesh bags were formed by gathering the edges of the mesh circle under each membrane in surface germination assay and tying them together with nylon thread or by gathering and tying the open side of buried bags from the buried germination assay. All bags were incubated in $2 \%$ non-fat milk dissolved in phosphate buffered saline, $\mathrm{pH} 7.2$, (PBS) for $30 \mathrm{~min}$. The milk was drained, bags were incubated for $1 \mathrm{hr}$ in monoclonal antibody 32B11 (Wright et al., 1996). Following three 5 min rinses with PBS plus Tween 20 (PBST), bags were incubated in FITC-tagged anti-mouse IgM for $1 \mathrm{hr}$. Bags were rinsed with PBST three times and PBS in a final rinse. All incubations and rinses were performed on a tilt table. After the final incubation, membranes were removed from the bags, cut in half, placed on microscope slides, and mounted in Vectashield ${ }^{\circledR}$ fluorescent mounting medium (Vector 
Laboratories, Inc.). Fluorescence was observed with a Nikon Optiphot compound microscope equiped with an Episcopic-Fluorescence attachment EF-D with a band pass combination BP450BP490 exciter filter, a diachronic chromatic beam splitter FT-510 filter, and a longwave pass LP520 barrier filter.

\section{Spore counts and statistical analysis}

Spores were scored into one of three categories: (i) germinated, as evidenced by presence of a germ tube; (ii) dead, based on change from yellow-green to dark brown contents (for Gi. gigantea only); or (iii) static, as determined by spores which appeared healthy and failed to germinate. Percentages of germinated or dead spores were calculated from the total number of spores scored at a given time. If a spore had germinated and then died, it still was placed in the germinated category. Data were tested for homogeneity of variance according to Levene's test prior to analysis of variance (ANOVA). Appropriate log and sine transformations were performed to establish equal variance. Significant difference was determined by application of Students's t-test at the 0.05 level. All statistical analyses were performed with JMP ${ }^{\circledR} 3.1$. If the variances were not homogenous after transformation, statistical difference was determined using maximum likelihood with one iteration after grouping according to variance with $\mathrm{SAS}{ }^{\circledR}$ 7.0. Statistical difference was indicated by differences between the least squares means at 0.05 .

\section{RESULTS}

Iron oxide was more toxic to spores of Gi. gigantea than G. etunicatum in the surface assay. In Gi. gigantea isolate MA453A, percentage germination declined significantly in sand amended with $0.5 \%$ hematite and was almost completely suppressed in sand with $1.5 \%$ hematite ( $\mathrm{F}<0.0001)$. Also, spore mortality was significantly higher for $1.5 \%$ hematite amended sand than both unamended and $0.5 \%$ hematite amended sand (F<0.0001) (Fig. 4). The few spores germinating in the $1.5 \%$ hematite treatment formed only short germ tubes and then died, while the germ tubes in unamended sand treatments were frequently extensive (Fig. 2A). A period of dormancy existed for all spores, as exhibited by a significant difference for percentage germination between the no iron treatment at 6 days and the later three scoring dates $(\mathrm{F}=0.0056)$. Isolate PA125 Gi. gigantea exhibited similar but less dramatic responses (Fig. 5). Percentage germination declined with the added hematite, but neither it nor percentage mortality differed significantly in the three treatments at the 0.05 level.

Spores of the two isolates of G. etunicatum did not differ significantly in percentage germination among iron treatments (Fig. 6). Spore mortality could not be detected visually in these spores and thus was not enumerated. However, the high rate of germination suggested low mortality.

Buried spores of Gi. gigantea (MA453A) and G. etunicatum (NE108A) did not differ significantly in percentage germination when exposed to hematite treatments (Fig. 7-8). Spores of Gi. gigantea also did not differ in percentage mortality (Fig. 7).

Germ tubes of both Gi. gigantea and G. etunicatum spores showed no evidence of immunofluorescence after treatment with the antiglomalin antibody (MAb 32B11). 


\section{DISCUSSION}

Considerable variation in effects of hematite on germination and mortality existed for isolates of both species used in this study. Each isolate had a different cultural history and different lengths of cold storage. So, this result was not unexpected, since these and other variables impact directly on rate and frequency of germination (Brundrett and Juniper, 1995; Koske, 1981; Safir et al., 1980; Siqueira et al., 1985; Sylvia and Schenck, 1983). Clearly, Gi. gigantea PA125 spores did not suffer the same degree of mortality as those of isolate MA453A of the same specieswhen exposed to higher concentrations of hematite (Figs. 4-5). The lower rates of germination by $\mathrm{Gi}$. gigantea isolate PA125 in the unamended treatment (Fig. 5) and by isolate MA453A in both the unamended and $1.5 \%$ iron (Fig. 7) suggest that spore dormancy was a factor. The effects of hematite appeared to be immediately toxic to spores of Gi. gigantea (Fig.

4 and 5). Similar toxic effects were observed with aluminum in acud soils, which is atomically related to iron (Bartolome-Esteban and Schenck, 1994). In addition, effects varied among isolates of Glomus and Gigaspora in the present study and in that of Bartolome-Estaban and Schenck (1994).

The spore wall layer from which the germ tube originates in spores of Gi. gigantea appears to be continuous (Maia et al., 1994), so that the inner contents of the spore are protected from exogenous compounds such as hematite. However, micropores (170-330 nm) have been observed in the septum of the germ tube so that upon emergence through the spore wall, a sharp, jagged flap is formed on the spore wall outer layer (Maia et al.,1994; Siqueira et al., 1985). Iron oxide crystals which are 17-35 nm (Torrent et al.,1994) may enter through these openings and disrupt the internal contents of the spore. Alternatively, iron oxide may react chemically with a protein or other germination factor that the spore requires to germinate.

These assays were conducted at a neutral $\mathrm{pH}$. In this environment, hematite has no charge surface charge (McBride, 1994). Without a charge association, aggregation of hematite crystals occurs (McBride, 1994). These aggregated crystals created a barrier against water. The hematite that coated spores and water in the plates and the mesh of the buried bags may have, therefore, excluded water from the spore surface. This would have reduced the water potential near the spores that is necessary for spore germination (Brundrett and Juniper; 1995, Koske, 1981; Siqueira et al., 1985; Sylvia and Schenck, 1983).

Gigaspora is completely reliant on spores as infective propagules and the toxic effects of hematite could contribute to the notable absence of this genus in many arid, semiarid, and calcareous soils (Kabata-Pendias and Pendias, 1984; Stutz and Morton, 1996; Siqueira et al.,1985). A component of this selectivity may be composition of the spore wall. Glomus species have $\beta-1,3$ glucans in their cell wall (Gianinazzi-Pearson et al., 1994) that may interact favorable with iron oxide, whereas Gigaspora species do not have these polysaccharides.

Germination was completely inhibited by hematite in only one isolate of the fungi studied, yet colonization was completely inhibited by all fungi in pot cultures (Appendix A). Clearly other variables were impacting on invasiveness of fungal isolates following spore germination. Roots in pots were coated with iron oxide which may have created a barrier for 
hyphal ingress. Aquatic plants are mycorrhizal, despite an iron oxide zone in the rhizosphere. Sorghum bicolor, used in the preliminary experiment in Appendix A, is a terrestrial plant species and rhizosphere processes are likely to be quite different from aquatic plants. Few viable spores are found in wetland areas and mycorrhizal spread is hypothesized to occur in this anaerobic environment from colonized roots (Charvat, pers. commun.; Stenlund and Charvat, 1994; Venkataramanan et al., 1982). Preponderance of hyphal versus spore propagules also may be a way for an arbuscular fungus to circumvent the possible toxic effects of iron oxide on spores.

Immunofluorescent glomalin was not found on germ tubes from germinating spores. This and the results from other studies indicate that glomalin does not play a role in spore germination (Wright et al., 1996; unpublished results). Since no fungal structures were formed in pots containing high iron oxide concentrations, the impact of iron oxide on glomalin production after colonization is initiated remains unknown.

\section{LITERATURE CITED}

Bartolome-Esteban, H. and N.C. Schenck. 1994. Spore germination and hyphal growth of arbuscular mycorrhizal fungi in relation to soil aluminum saturation. Mycologia 86:217226.

Biermann, B.J. and R.G. Linderman. 1983. Increased geranium growth using pretransplant inoculation with a mycorrhizal fungus. Journal of the American Society for Horticultural Science 108:972-976.

Brundrett, M. 1991. Mycorrhizas in natural ecosystems. Advances in Ecological Research 21:171-213.

Brundrett, M. and S. Juniper. 1995. Non-destructive assessment of spore germination of VAM fungi and production of pot cultures from single spores. Soil Biology and Biochemistry 27:85-91.

Daniels Hetrick, B.A. and G.W.T. Wilson, 1989. Suppression of mycorrhizal fungus spore germination in non-sterile soil: Relationship to mycorrhizal growth response in big bluestem. Mycologia 81:382-390.

Gianinazzi-Pearson, V. M-C. Lemoine, C. Arnould, A. Gollotte, and J.B. Morton. 1994. Localization of $\beta(1 \rightarrow 3)$ glycans in spore and hyphal walls of fungi in the Glomales. Mycologia 86:478-485.

Kabata-Pendias and Pendias. 1984. Trace Elements in Soils and Plants. CRC Press, Inc. Boca Raton, Florida. 233-238.

Koske, R.E. 1981. Gigaspora gigantea: Observations on spore germination of a VAmycorrhizal fungus. Mycologia 73:288-300.

Maia, L.C., J.W. Kimbrough, and G.L. Benny. 1994. Ultrastructure of spore germination in Gigaspora albida (Glomales). Mycologia 86:343-349.

Mayo, K., R.E. Davis, and J. Motta. 1986. Stimulation of germination of spores of Glomus versiforme by spore-associated bacteria. Mycologia 78:426-431.

McBride, M.B. 1994 Environmental Chemistry of Soils. Oxford University Press: New York.

Morton, J.B. 1990. Species and clones of arbuscular mycorrhizal fungi (Glomales, Zygomycetes): Their role in macro- and microevolutionary processes. Mycotaxon 37:493-515. 
Morton, J.B. 1993. Problems and solutions for the integration of glomalean taxonomy, systematic botany, and the study of endomycorrhizal phenomena Mycorrhiza 2:97-109.

Morton, J.B. and Benny, G.L. 1990. Revised classification of arbuscular mycorrhizal fungi (Zygomycetes): A new order, Glomales, two new suborders, Glomineae and Gigasporineae, and two new families, Acaulosporaceae and Gigasporaceae, with an emendation of Glomaceae. Mycotaxon 37:471-491.

Safir, G.R. 1994. Involvement of cropping systems, plant produced compounds, and inoculum production in the functioning of VAM fungi. In: Mycorrhizae and Plant Health. Eds. F.L. Pfleger and R.G. Linderman. APS Press, St. Paul, MN. 239-259.

Safir, G.R., S.C. Coley, J.O. Siqueira, and P.S. Carlson. 1980. Improvement and synchronization of VA mycorrhiza fungal spore germination by short-term cold storage. Soil Biology and Biochemistry 22:109-111.

Siqueira, J.O., D.M. Sylvia, J. Gibson, and D.H. Hubbell. 1985. Spores, germination, and germ tubes of vesicular-arbuscular mycorrhizal fungi. Canadian Journal of Microbiology 31:965-972.

Smith, S.E. and D.J. Read. 1997. Mycorrhizal symbiosis, $2^{\text {nd }}$ Edition. Academic Press: San Diego.

Stenlund, D.L. and I.D. Charvat. 1994. Vesicular arbuscular mycorrhizae in floating wetland mat communities dominated by Typha. Mycorrhiza 4:131-137.

Stutz, J.C. and J.B. Morton. 1996. Successive pot cultures reveal high species richness of arbuscular endomycorrhizal fungi in arid ecosystems. Canadian Journal of Botany 74:1883-1889.

Sylvia, D.M. and N.C. Schenck. 1983. Germination of chlamydospores of three Glomus species as affected by soil matric potential and fungal contamination. Mycologia 75:30-35.

Tommerup, I.C. 1983. Spore dormancy in vesicular-arbuscular mycorrhizal fungi. Transactions of the British Mycology Society 81:37-45.

Tommerup, I.C. 1984. Effect of soil water potential on spore germination by vesicular-arbuscular mycorrhizal fungi. Transactions of the British Mycology Society 83:193-202.

Torrent, J., U. Schwertmann, and V. Barron. 1994. Phosphate sorption by natural hematites. European Journal of Soil Science 45:45-51.

Venkataramanan, M.N., H.D. Singh, and J.N. Baruah. 1982. Note on the occurrence of endotrophic mycorrhiza in water-hyacinth and its significance in agriculture. Indian Journal of Agricultural Science 52:39-40.

Wright, S.F. and R.L. Anderson. 1999. Aggregate stability and glomalin in alternative crop rotations for the Central Great Plains. Biology and Fertility of Soils (In Press).

Wright, S.F., and A. Upadhyaya. 1998. A survey of soils for aggregate stability and glomalin, a glycoprotein produced by hyphae of arbuscular mycorrhizal fungi. Plant and Soil 198:97-107.

Wright, S.F., M. Franke-Snyder, J.B. Morton, and A. Upadhyaya. 1996. Time-course study and partial characterization of a protein on hyphae of arbuscular mycorrhizal fungi during active colonization of roots. Plant and Soil 181:193-203. 


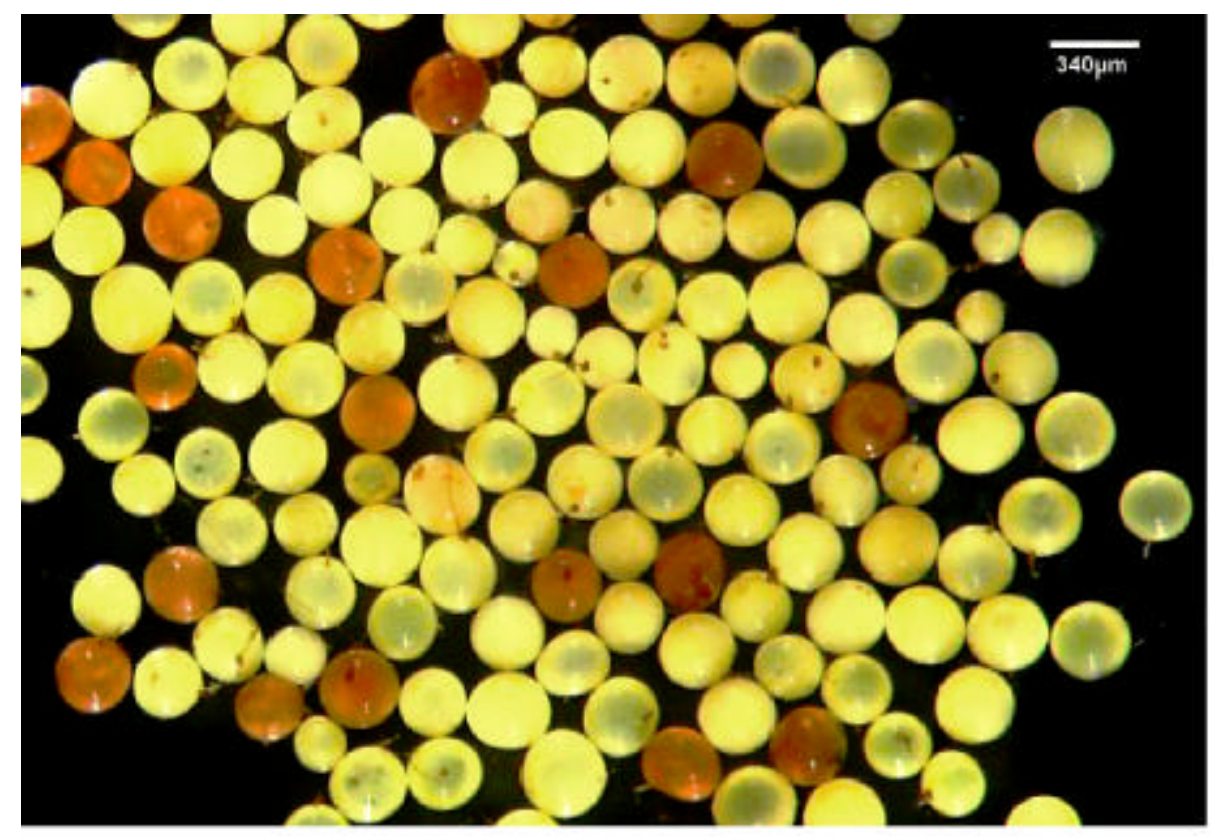

Figure 1. Extracted dead ( $\square$ ) spores can easily be distinguished from live spores ( ) of Gi. gigantea. 

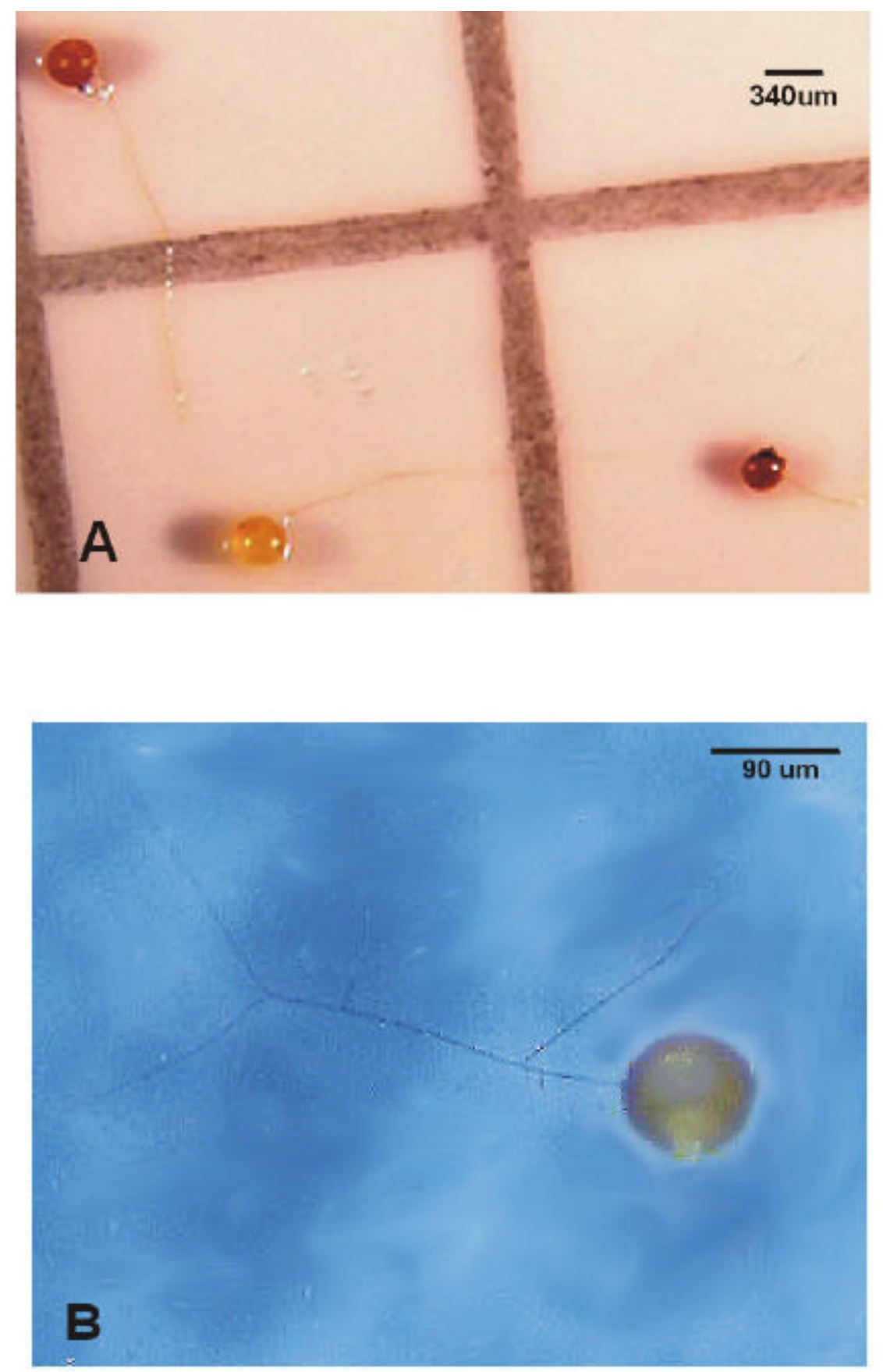

Figure 2. Germinating spore of Gi. gigantea (A) and $G$. etunicatum (B). The long, readily identifiable germ tube formed by Gi. gigantea can easily be seen without staining (A), whereas the germ tube of $G$. etunicatum is much thinner and needs to be stained by $0.05 \%$ Direct Blue to be identified $(B)$. 
A

Petri plate

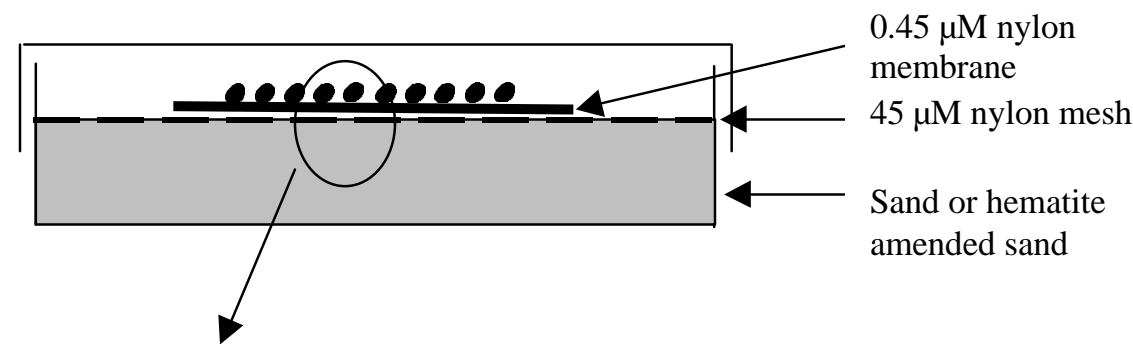

Surface view

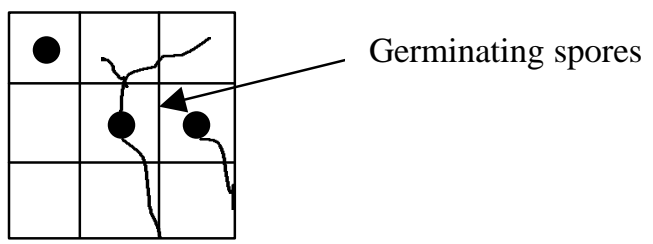

B

$7.5 \mathrm{~cm}$ ID pot

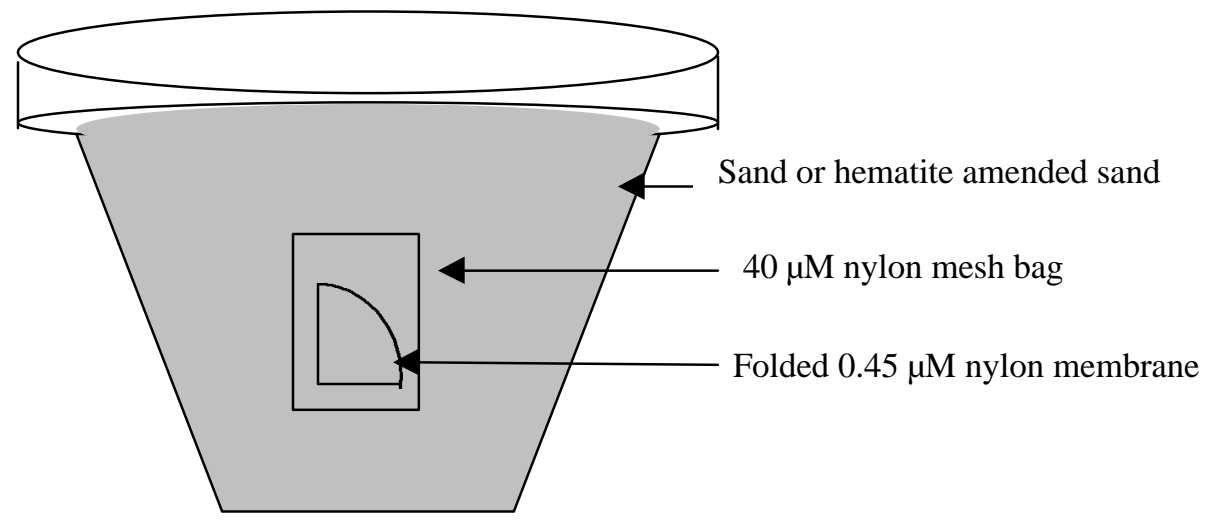

Figure 3. Spore germination on a nylon membrane on the surface of (A) or buried in (B) a sterile sand or hematite amended sand. 


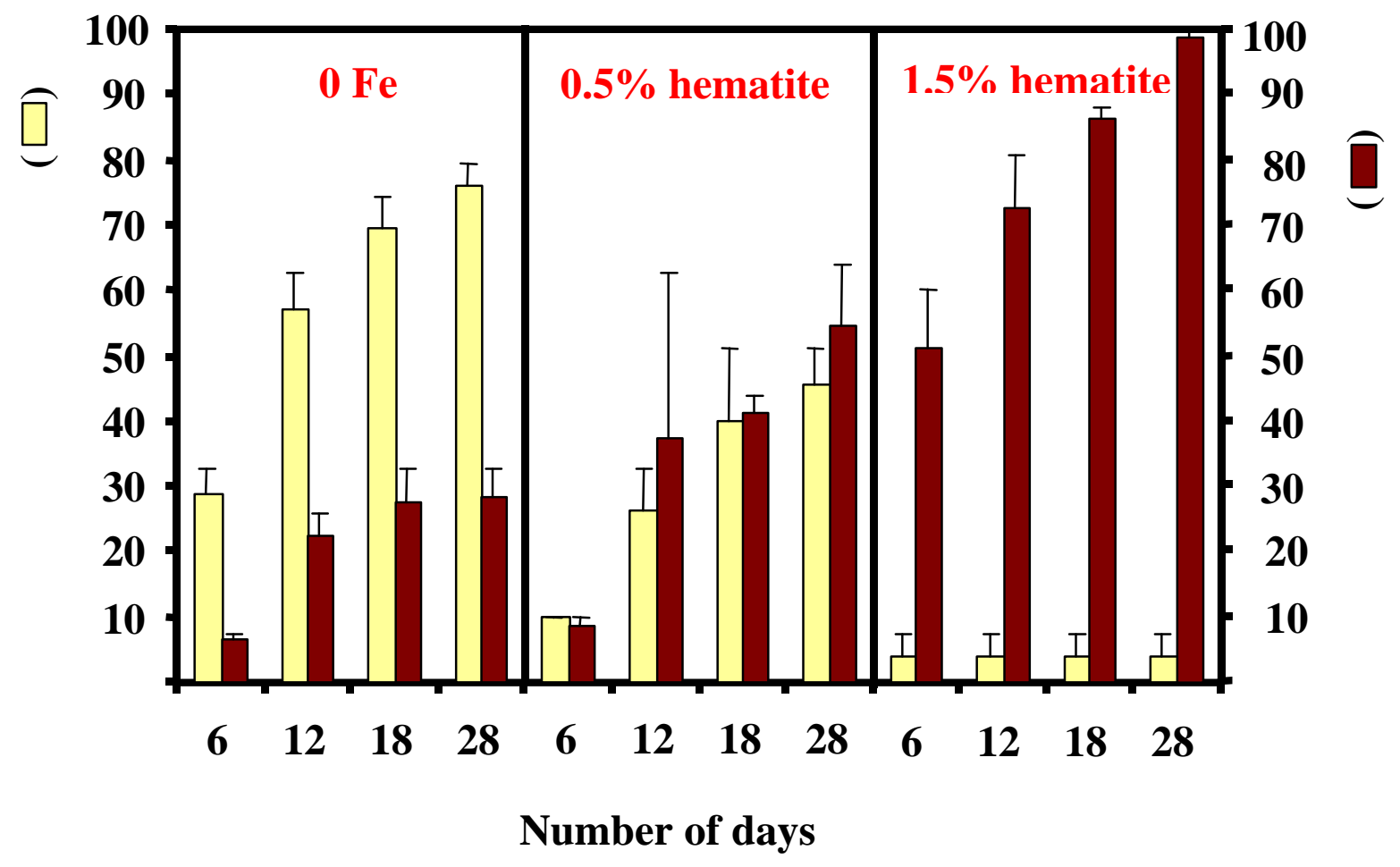

Figure 4. Surface germination assay: Percentage germination and mortality of $\mathrm{Gi}$. gigantea (MA453A) spores exposed to three iron oxide treatments: $0 \mathrm{Fe}, 0.5 \%$ hematite, and $1.5 \%$ hematite. 


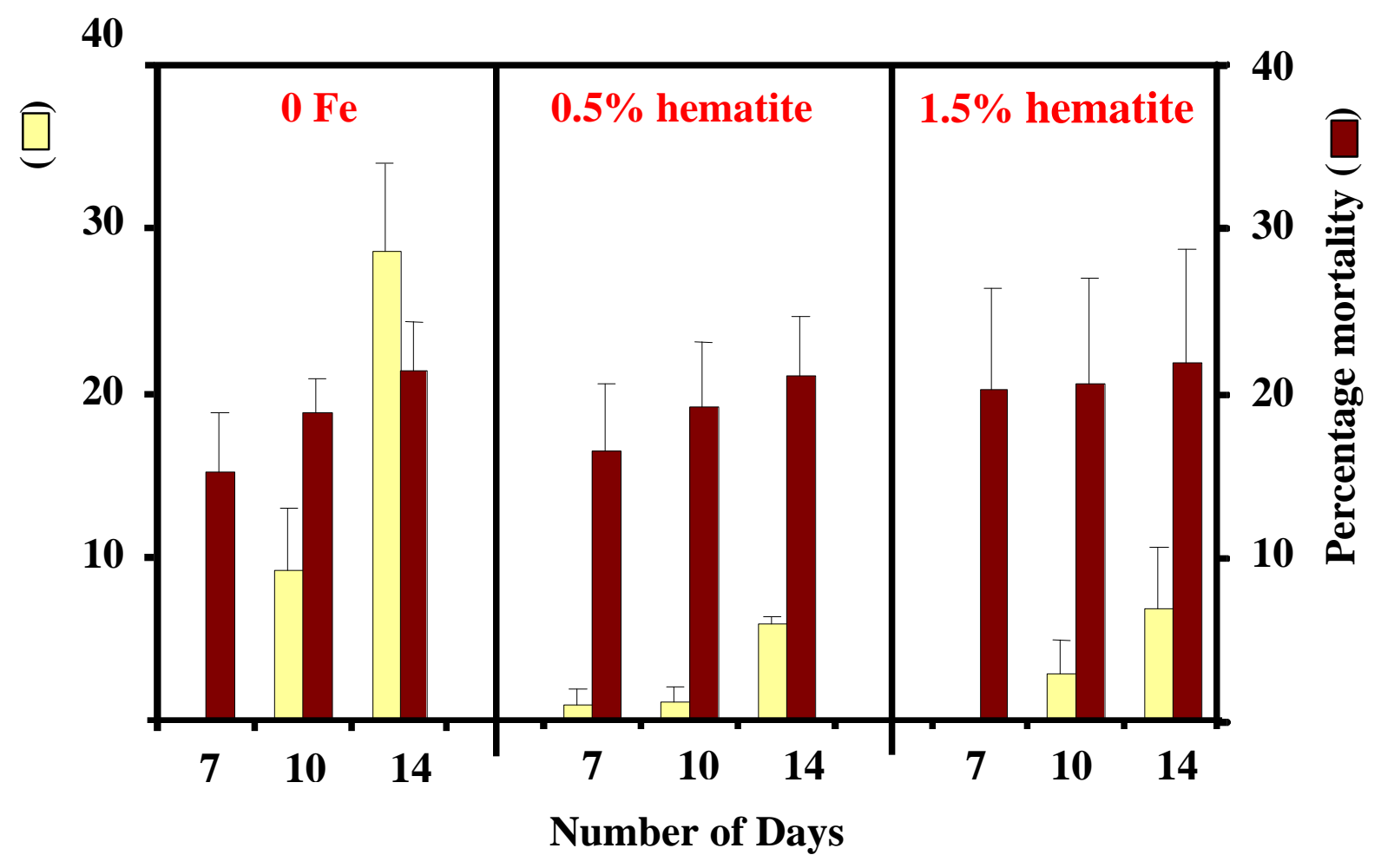

Figure 5. Surface germination assay: Percentage germination and mortality of Gi. gigantea (PA125) spores exposed to three iron oxide treatments: $0 \mathrm{Fe}, 0.5 \%$ hematite, and $1.5 \%$ hematite. 


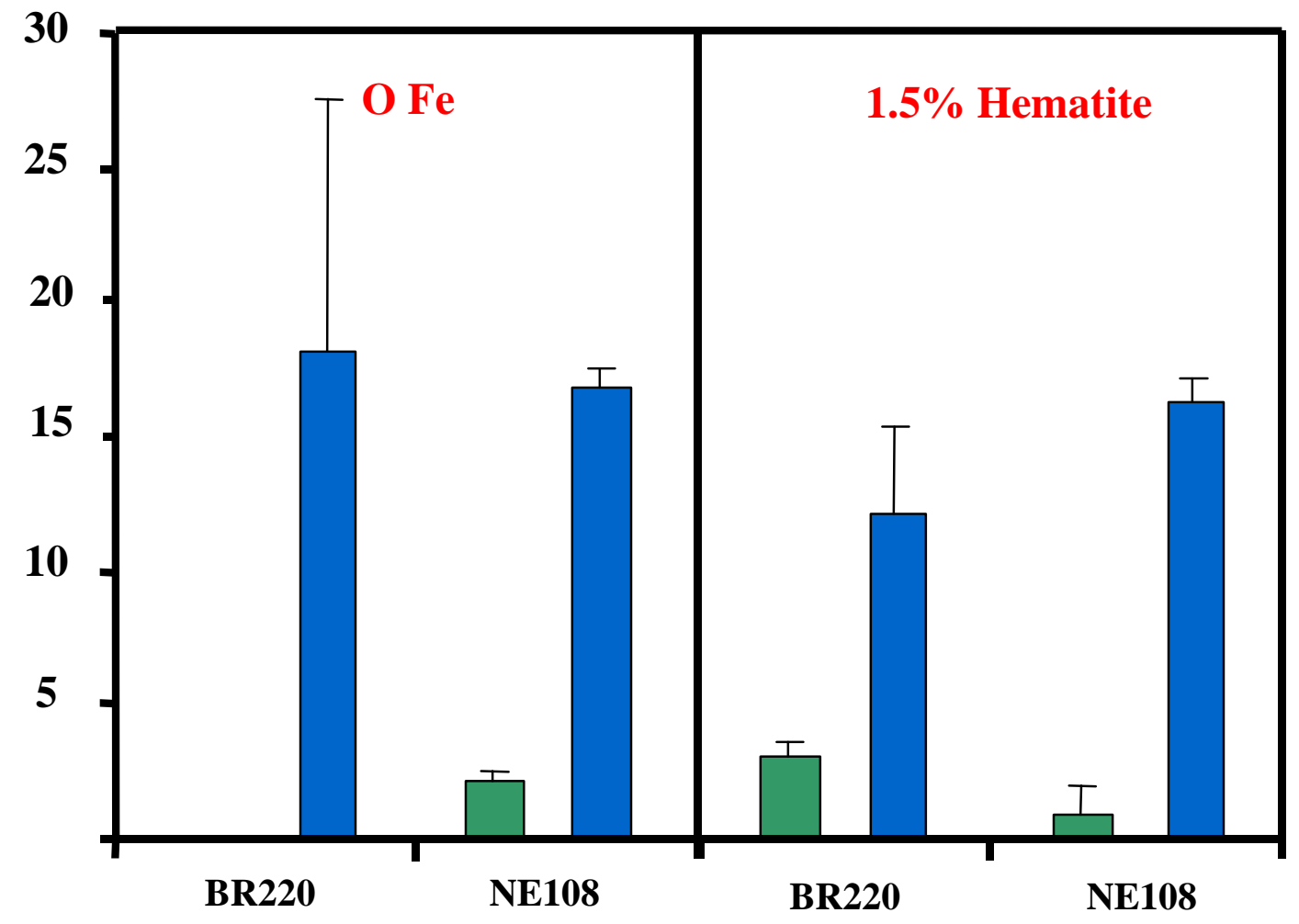

Figure 6. Surface germination assay: Percentage germination of $G$. etunicatum (BR220 and NE108A) spores after $14(\square)$ and 28 ( $\square$ ) days exposed to two iron oxide treatments: 0 Fe and $1.5 \%$ hematite. 


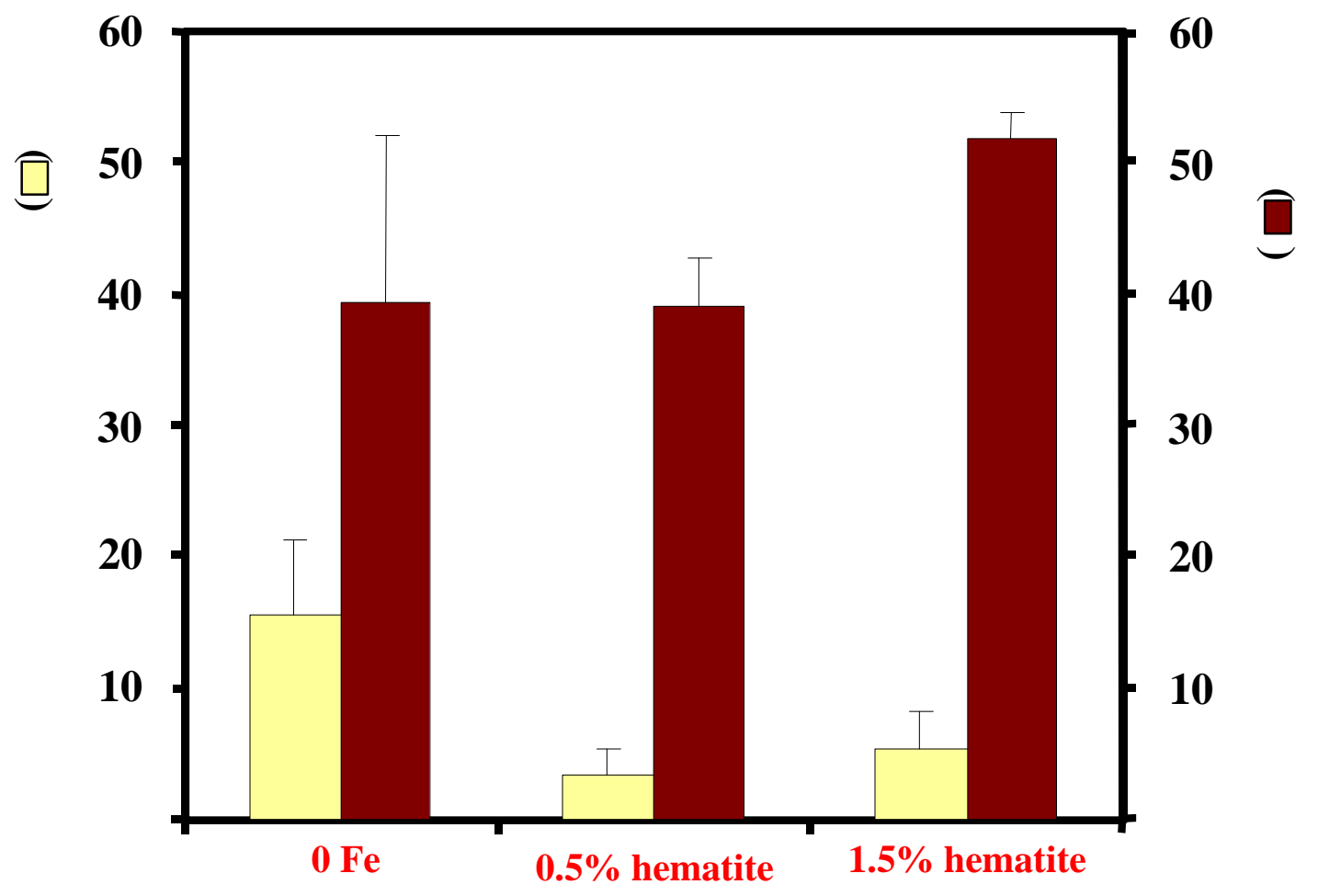

Figure 7. Buried germination assay: Percentage germination and mortality of $G i$. gigantea (MA453A) spores in pots after 14 days buried in pots with three iron oxide treatments: $0 \mathrm{Fe}, 0.5 \%$ hematite, and $1.5 \%$ hematite. 


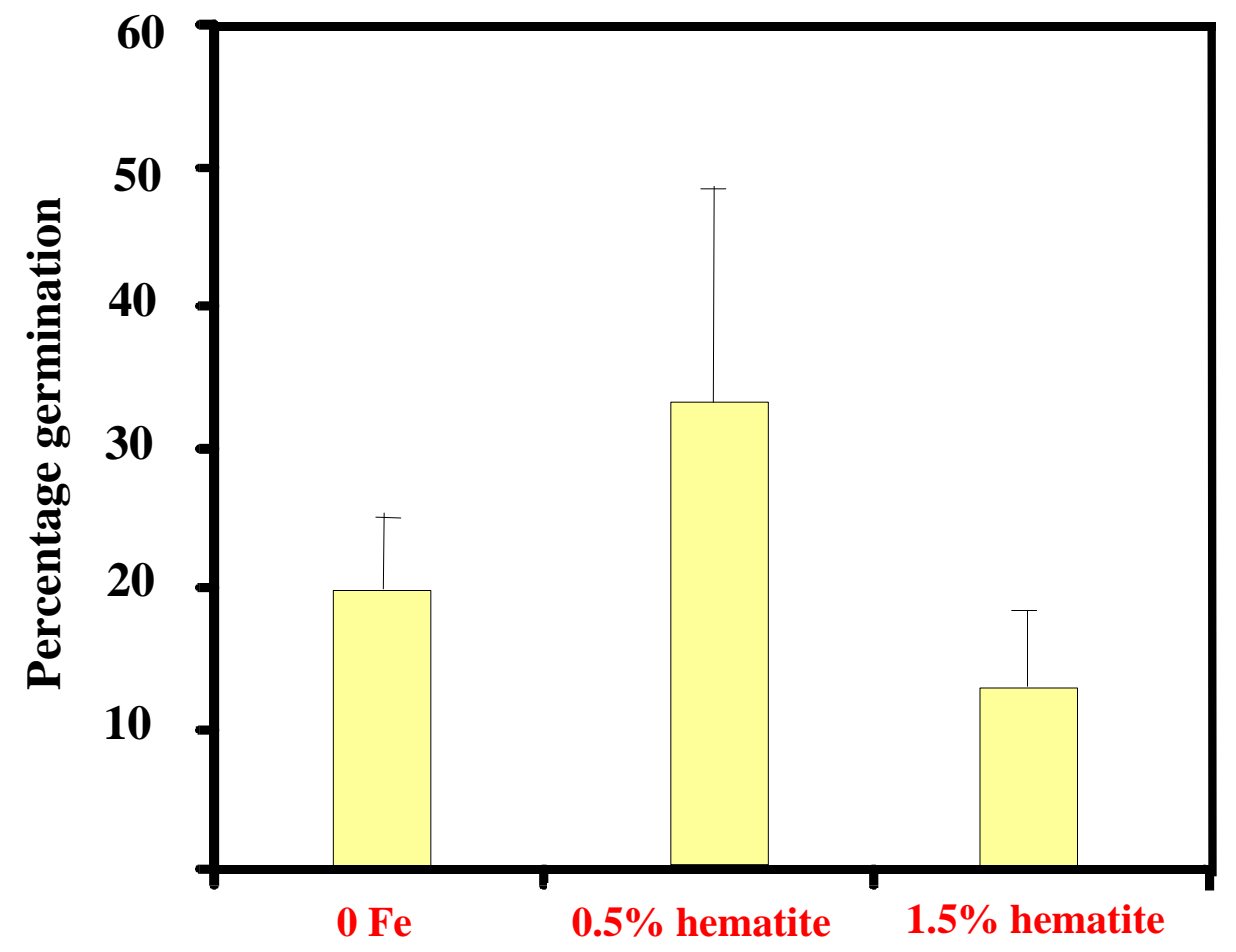

Figure 8. Buried germination assay: Percentage germination of $G$. etunicatum (NE108A) spores after 32 days buried in pots with three iron oxide treatments: $0 \mathrm{Fe}$, $0.5 \%$ hematite, and $1.5 \%$ hematite. 


\section{CHAPTER TWO}

\section{A GLYCOPROTEIN PRODUCED BY NONMYCORRHIZAL PLANTS THAT IS CROSS-REACTIVE WITH A MONOCLONAL ANTIBODY AGAINST GLOMALIN}




\section{INTRODUCTION}

The 158 species of symbiotic arbuscular mycorrhizal fungi (AMF) described to date are classified by subcellular structure of spores (Morton, 1988). In contrast, the morphology of fungal structures that contribute to mycorrhizal structure (arbuscules, vesicles, auxiliary cells, intraradical and extraradical hyphae) are shared among species, and resolve taxa only at the family level and above (Morton and Bentivenga, 1994). Other methods are being developed, therefore, to measure the extent to which roots are colonized by different species comprising the fungal community.

Immunological procedures are useful tools for detecting a wide range of antigens (proteins, carbohydrates, glycoproteins). The enzyme-linked immunosorbent assay (ELISA) provides a rapid means to detect and quantify an antigen whereas immunofluorescent methods determine the location and distribution of antigenic molecules. In both methods, antibody binds to a specific site (i.e. a few amino acids or monosaccharides) on the antigen macromolecule. Monoclonal antibodies (Mabs) in many biological systems can be species specific and sometimes even structural, strain or race specific (Wycoff et al., 1987; Xia et al., 1992; Green et al., 1994). In other cases, MAbs can bind to common carbohydrate groups of different proteins, to common protein domains formed by proteolytic cleavage, or to glycoproteins with different glycosylation patterns. The first monoclonal antibodies specific to an AMF was against Glomus occultum (Wright et al., 1987). This species was selected because its mycorrhiza stains lightly and is difficult to detect (Adelman and Morton, 1986). Additional MAbs were produced against Glomus intraradices, but none were species-specific. One MAb, 32B11, reacted with a glycoprotein coating the surface of all AMF hyphae in Glomales but did not react with any other fungal taxa (Wright et al., 1996). The glycoprotein was named "glomalin" to indicate its restriction to Glomales. Glomalin appears to be moderately glycosylated (Wright, unpubl.), so its glycosyl groups as well as protein moieties may be reactive sites for antibodies.

Glomalin has a high iron concentration (2-5\%) (Wright and Anderson, 1999) in addition to its carbon content (20-30\%). A preliminary experiment was established to evaluate effects of iron of differing solubility and concentration on mycorrhizal development and glomalin accumulation. This study, involving growth of mycorrhizal and nonmycorrhizal sorghum in acid-washed sand with unavailable (hematite) and available (FeEDDHA) iron sources, revealed the accumulation of a glycoprotein cross-reactive with MAb 32B11 in pots with nonmycorrhizal plants (Appendix A). The glycoprotein concentrations in these pots were similar to those of mycorrhizal plants, but both were abnormally low in part because plants were stressed by iron deficiencies in the growth media and low ambient light. Differences between total glycoprotein and immunoreactive glycoprotein concentrations were not significant. The objectives of these experiments were to: (i) verify immunoreactive glycoprotein accumulation on nonmycorrhizal sorghum grown in pots under iron conditions identical to those of the preliminary experiment, (ii) quantify accumulation of this glycoprotein by nonmycorrhizal sorghum and tall fescue in pot cultures, and (iii) purify and chemically analyze glycoprotein extracts. 


\section{MATERIALS AND METHODS}

Sand potting medium. Coarse ( $85 \%$ of sand collected on \#50 mesh or less) and fine (68\% of sand on \#70 mesh or greater) silica sand was mixed 2:1, v/v. The sand mix was washed three times with $2-3 \mathrm{~N} \mathrm{HCl}$ to remove residual iron, and autoclaved at $121^{\circ} \mathrm{C}$ for $1 \mathrm{~h}$ with $50 \mathrm{mM}$

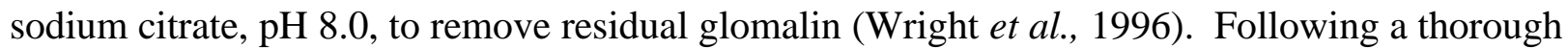
rinsing with distilled water, the sand was autoclaved at $121^{\circ} \mathrm{C}$ for $40 \mathrm{~min}$, and then dried.

Amendments to potting medium. Iron was added to potting medium as $0.5 \%$ or $1.5 \%$ (w/w) iron oxide (hematite). The presence of glomalin in hematite was determined by a $20 \mathrm{mM}$ citrate extraction followed by ELISA. Potting medium without hematite had iron added as 25 or $50 \mu \mathrm{M}$ FeEDDHA in the nutrient solution. Controls had no iron added. Each treatment (hematite-amended, FeEDDHA-amended, or unamended) was placed in $750 \mathrm{~cm}^{3}$ deepots (Stuewe and Sons, Inc., Corvallis, Oregon). The $\mathrm{pH}$ was adjusted to 5.5 or 8.0 by rinsing with $\mathrm{HCl}$ or $\mathrm{NaOH}$ solution at the appropriate $\mathrm{pH}$.

Nutrient solution. All of the pots were watered with half-strength nutrient solution (Millner and Kitt, 1995) without iron or with 25 or $50 \mu \mathrm{M}$ FeEDDHA at pH 5.5 or 8.0 (Appendix B), according to treatment.

Growth room conditions. All plants were maintained in a growth room under highintensity fluorescent lights with a photon flux density of $245 \mu \mathrm{mol} \mathrm{m}^{-2} \mathrm{~s}^{-1}$ at pot level, a 14-hour photoperiod, and an ambient temperature of $21-28^{\circ} \mathrm{C}$.

Harvest. Watering was terminated and shoots were excised and discarded. Roots were gently separated from the sand and subsampled for colonization and dry weight. The remaining root material was finely chopped and remixed with the potting media for protein extraction.

Mycorrhizal colonization. About half the roots (by volume) were cleared in boiling $10 \%$ $\mathrm{KOH}(\mathrm{w} / \mathrm{v})$ for $5 \mathrm{~min}$. Then, rinsed with water and acidified with $1 \% \mathrm{HCl}(\mathrm{v} / \mathrm{v})$ for $5 \mathrm{~min}$. Finally, the roots were stained with $0.05 \%$ Direct Blue (w/v) in a hot lactic acid, glycerol, and water (1:1:1) mixture for 5 min (Phillips and Hayman, 1970). Presence or absence of mycorrhizal colonization was assessed via the grid-line intersect method (Giovannetti and Mosse, 1980) under a stereomicroscope.

AMF spore extraction. A $50 \mathrm{~cm}^{3}$ subsample of pot contents was added to water in a blender, mixed using three $10 \mathrm{sec}$ bursts, and then decanted into nested 500 and $45-\mu \mathrm{m}$ sieves. The material retained on the $45-\mu \mathrm{m}$ sieve was rinsed into tubes containing a 20/60\% (w/v) sucrose solution and centrifuged at $100 \mathrm{xg}$ for $1 \mathrm{~min}$. This material was rinsed in a $45-\mu \mathrm{m}$ sieve, transferred with water into a Petri plate, and examined under a stereomicroscope for presence of AMF spores.

Protein extraction and concentration measurement. Protein was extracted by autoclaving the sample in $20 \mathrm{mM}$ citrate buffer, $\mathrm{pH} \mathrm{7.0,} \mathrm{at} 121^{\circ} \mathrm{C}$ for $1 \mathrm{~h}$. The extracted protein was analyzed for immunoreactive protein with the ELISA secondary antibody conjugation assay at concentrations of $0.025-0.125 \mu \mathrm{g}$ per $50 \mu \mathrm{l}$ (Wright et al., 1996). Protein concentration in the 
extract was estimated by the color of the extract and ELISA performed using various dilutions. In an ELISA, samples were placed in three replicate wells of a 96-well plate at concentrations of $0.025-0.125 \mu \mathrm{g}$ per $50 \mu \mathrm{l}$ and filled to a volume of $50 \mu \mathrm{l}$ with PBS (phosphate buffered saline, $\mathrm{pH}$ 7.4). Plates were dried overnight at room temperature. Wells were blocked with $2 \%$ non-fat milk in PBS to prevent non-specific attachment of protein to plastic not coated with antigen. After removal of the blocking buffer, monoclonal antibody clone (MAb 32B11) was incubated in wells for $1 \mathrm{~h}$. Wells were washed three times with PBST (phosphate buffered saline plus Tween 20), incubated for $1 \mathrm{~h}$ with an anti-mouse IgM, and washed again with PBST. ExtrAvidin peroxidase enzyme then was added and incubated for $1 \mathrm{~h}$. Following four washes with PBST, color was developed with ABTS (2,2'-Azinobis(3-ethylbenzthiazoline-sulfonic acid) and hydrogen peroxide in a $1.05 \%(\mathrm{w} / \mathrm{v})$ citric acid solution at $\mathrm{pH} 4.0$. Color intensity was determined by reading the plate at $410 \mathrm{~nm}$ after $15 \mathrm{~min}$ and concentration was calculated by comparison to a $0.025-0.125 \mu \mathrm{g}$ standard curve. All of the incubations, except for the color development, were performed on a tilt table. To test for the possibility of nonspecific binding by MAb 32B11 in the ELISA, an anti-Rhizobium IgM MAb antibody was periodically substituted for MAb 32B11.

\section{Experiment 1-Glycoprotein accumulation by nonmycorrhizal sorghum}

Sand potting media amended with iron, as described above, was used. Sorghum (Sorghum bicolor L. Moench) seeds were pregerminated in sterile, acid-washed sand. After 7-9 days, three seedlings were transplanted into each deepot. Pots were then watered with nutrient solution and placed in a growth room, as described above. There were three replicate pots per treatment (total of 36 pots).

After 56 days, pots were harvested and mycorrhizal colonization and spore extraction were performed as outlined above. A 0.25 -g sample of the potting media/root mixture was extracted and assayed for immunoreactive protein according to the procedures above.

\section{Experiment 2-Verification of absence of AMF contamination in nonmycorrhizal pots}

To rule out the possibility of glycoprotein accumulation by undetected levels of AMF, the unsampled contents of putative nonmycorrhizal pots were used to set up a second propagation cycle to increase any fungal biomass to a detectable level. Root fragments and potting media from each treatment described above were each mixed by treatment, placed in $350 \mathrm{~cm}^{3}$ deepots and planted with 15-20 sterile sudangrass [Sorghum sudanese (Piper) Staph.] seeds. Pots were watered daily with water and plants were grown in a growth room under the same conditions described above.

After 56 days, a potting media/root subsample was removed with a 1-cm ID corer and extracted in $20 \mathrm{mM}$ citrate, $\mathrm{pH} 7.0$, at $121^{\circ} \mathrm{C}$ for $1 \mathrm{~h}$. Extract was assayed for immunoreactive protein with ELISA, described previously.

After 106 days, watering ceased and cultures were harvested by removing and disposing

of the shoots and gently separating roots from pot contents. Both a sand subsample from the pot 
and half of the roots were extracted with $20 \mathrm{mM}$ sodium citrate at $\mathrm{pH} 7.0$ at $121^{\circ} \mathrm{C}$ for $1 \mathrm{hr}$ and assayed for immunoreactive protein against a standard curve at 0.025-0.125 $\mu \mathrm{g} / \mathrm{well}$.

Colonization and presence of spores were assessed as described above.

\section{Immunoreactivity of roots and hyphae separately}

Roots and hyphae were partitioned into separate fractions to determine if the immunoreactive protein was associated with the roots or with any nonmycorrhizal fungi present. A subsample of the potting media was force rinsed through nested sieves of 500, 150 and $45 \mu \mathrm{m}$. Roots collected on the $500-\mu \mathrm{m}$ sieve and hyphae on the $45-\mu \mathrm{m}$ sieve were extracted for protein with $20 \mathrm{mM}$ citrate. Immunoreactive protein concentration was again measured via ELISA as described above.

\section{Glycoprotein accumulation by nonmycorrhizal C3 and C4 grasses}

Sand potting medium, as described above, was used except that the sand was not acidwashed. Sorghum or tall fescue (Festuca arundinacea Schreb.) seeds were placed in the deepots, which were then put into the growth room. Each grass was grown in one of three treatments replicated four times: (i) no amendments in the sand mixture; (ii) $1.5 \%$ hematite added to the sand prior to potting; and (iii) a $50 \mu \mathrm{M}$ FeEDDHA added to the Hoagland's solution. Each pot was watered once daily with nutrient solution as outlined above.

After 56 days, pot contents were sampled with a 1-cm ID corer and immunoreactive protein concentration was measured by ELISA, as described above. Plants were maintained for an additional 46 days. At harvest, shoots were removed at the soil line, but were not disposed of. Instead, fresh weight was measured, and leaves were randomly sampled and pooled to test for chlorophyll content.

Chlorophyll measurement. To measure concentration of chlorophyll a and b, leaf tissue was chopped finely, weighed, and placed in test tubes containing $10 \mathrm{ml}$ of methanol. The tubes were vortexed, and incubated at room temperature overnight in the dark. After 20-24 hrs, tubes were re-vortexed and allowed to settle for $15 \mathrm{~min}$. Supernatant was transferred to cuvettes and read with a spectrophotometer at 652, 665, and $750 \mathrm{~nm}$. Samples with absorbance readings above 1.000 were diluted $(1: 10, \mathrm{v} / \mathrm{v})$ with methanol. Chlorophyll a and b concentration were calculated using equations by Porra et al. (1989) for methanol extraction and determined on a per gram basis for foliar tissue dry weight.

Roots were manually separated from pot contents without washing. Mycorrhizal colonization and AMF spore density was assessed as described above. The remaining root mass was extracted for protein, as outlined above. Total protein concentration was measured using the Bio-Rad ${ }^{\circledR}$ protein assay (Wright et al., 1996; Wright and Upadhyaya, 1996). Protein concentration was estimated by the color of the extract. Dilutions were made so that protein concentration ranged between 1.25-5.0 $\mu \mathrm{g}$. The appropriate dilution of each sample was loaded into three replicatewells of a microtiter plate, which were filled to $200 \mu \mathrm{l}$ with PBS. Fifty $\mu$ l of Bio-Rad ${ }^{\circledR}$ protein dye was added to each well, mixed thoroughly, and compared with a Bovine 
Serum Albumin (BSA) standard curve. Immunoreactive protein was measured by ELISA as described above.

\section{Isolation of contaminants}

To test for the presence of protein on a contaminant in the potting medium, $0.5 \mathrm{~g}$ of pot contents from one pot of each of the sorghum and tall fescue treatments was sprinkled onto a nutrient agar (NA) plate. Once isolated colonies were obtained, they were transferred onto a $0.45-\mu \mathrm{m}$ membrane atop another NA plate. These membranes were extracted for protein and measured for immunoreactive protein, as described above.

\section{Glycoprotein purification and analysis}

\section{Immuno-dot blot assay of nonmycorrhizal extracts}

An SDS-PAGE gel with Coomassie Blue staining and a western blot failed to produce any discernible bands. Comparisons then were made of extracts from nonmycorrhizal sorghum cultures that were either untreated or incubated in 3\% SDS for $10 \mathrm{~min}$ in immuno-dot blot assays (Wright and Morton, 1989). Immuno-dot blot assays and ELISAs also were performed on extracts separated into two fractions using Centricon ${ }^{\circledR} 50$ tubes. Tubes were filled with 2 mls of extract and centrifuged at $1000 \mathrm{x}$ g for $20 \mathrm{~min}$. The retentate fraction contained molecules larger than $50 \mathrm{KD}$ (kilodaltons) and the filtrate fraction consisted of molecules less than $50 \mathrm{KD}$.

One $\mu \mathrm{l}$ of each sample was placed on a $0.45 \mu \mathrm{m}$ nitrocellulose membrane and dried overnight. The membrane was incubated for $15 \mathrm{~min}$ in $2 \%$ non-fat milk. After removal of the milk, the monoclonal antibody 32B11 was added and incubated for $1 \mathrm{~h}$. The antibody was decanted and PBST was incubated for three replicate 5-min intervals. A biotinylated anti-mouse IgM antibody was added for $1 \mathrm{~h}$, poured off and followed by rinsing with PBST. After this wash, ExtrAvidin peroxidase was incubated for $1 \mathrm{~h}$. The membrane was then washed three times with PBST and once with tris buffered saline (TBS), pH 7.4 for 5 min. The color developer (containing 4-chlor-1-naphthol in ice cold methanol, TBS and hydrogen peroxide) was added and incubated until color developed. All incubations including the washes and color development were performed on a tilt table. The membrane was stored dry at room temperature.

\section{Protein purification and lyophilization}

After all the analyses were conducted, protein was extracted by autoclaving in $50 \mathrm{mM}$ citrate, $\mathrm{pH} 8.0$, at $121^{\circ} \mathrm{C}$ for $1 \mathrm{hr}$ from all of the remaining potting material of one replicate of each treatment for the two grasses (sorghum and tall fescue). Extracted protein was mixed 1:1 (v/v) with ice cold $20 \%$ TCA and incubated on ice for $1 \mathrm{~h}$. After incubation, the samples were centrifuged to collect the precipitated protein. The supernatant was decanted and the precipitate reconstituted with $100 \mathrm{mM}$ borate, $\mathrm{pH}$ 9.0. Samples were dialyzed in $10 \mathrm{mM}$ borate, $\mathrm{pH} 8.0$ at room temperature with three changes in the dialysis solution every $12 \mathrm{hr}$. The dialyzed samples were centrifuged again at $11,180 \mathrm{x}$ g for $10 \mathrm{~min}$ to further remove impurities and frozen at $20^{\circ} \mathrm{C}$. Samples were placed in a freeze drier, and lyophilized protein was stored at room temperature until needed. 
Glycoprotein carbohydrate confirmation of lyophilized extract

A Glycoprotein Carbohydrate Estimation Kit was used to assay the lyophilized protein for glycosyl groups. Approximately $25 \mathrm{mg}$ of lyophilized protein was reconstituted in $1 \mathrm{ml}$ of Glycoprotein Assay Buffer, from which a $0.2 \mathrm{ml}$ subsample was examined for glycosyl group concentration (Appendix C).

SDS-PAGE gel of extracts from the two grasses

Lyophilized glycoprotein from the sorghum and tall fescue cultures was reconstituted to $2.5 \mu \mathrm{g} / \mu \mathrm{l}$. These were mixed with $4 \mu \mathrm{l}$ of pre-incubation buffer $(20 \mathrm{mM}$ citrate and $1 \mathrm{mM}$ EDTA, pH 9.3) and incubated overnight at $4^{\circ} \mathrm{C}$ (Wright et al., 1996). Forty $\mu$ l of sample buffer (pre-incubation buffer plus 3\% SDS and 1\% diothreiotol) was added and incubated in boiling water for 8 min. Samples were run on a $12.5 \%$ SDS gel using the PhastSystem ${ }^{\mathrm{TM}}$ (Pharmacia Biotech, Uppsala, Sweden). The PhastSystem ${ }^{\mathrm{TM}}$ uses a pre-made gel placed on top of a thin film of water in a gel box cooled to $15^{\circ} \mathrm{C}$. SDS buffer strips (made of $3 \%$ agarose with $0.20 \mathrm{M}$ tricine, $0.20 \mathrm{M}$ Tris and $0.55 \% \mathrm{SDS}, \mathrm{pH}$ 6.4) were placed at the top and bottom of the gel, which then was run at $10.0 \mathrm{~mA}$. After the program was complete, the gel was removed and developed with silver stain (PhastSystem ${ }^{\mathrm{TM}}$ File No. 210) (Appendix D). Following staining, the bands developed at room temperature and were compared to the banding patterns for glomalin.

\section{Immunofluorescence assay of nonmycorrhizal roots and hyphae}

Roots with associated hyphae were separated manually from the potting media of the first nonmycorrhizal sorghum plants or by forced water from the potting media of the sorghum and tall fescue plants and were examined for immunofluorescence. Roots and hyphae were incubated in 2\% non-fat milk blocking buffer for 30 min (Wright et al., 1996 and Wright, 1999). After the milk was decanted, the roots were incubated with MAb 32B11 for $1 \mathrm{~h}$. They were washed three times for $5 \mathrm{~min}$ with PBST and then incubated for $1 \mathrm{~h}$ with an FITC tagged goat anti-mouse IgM. Again, they were washed with PBST and then stored in PBS until they could be mounted in VectaShield ${ }^{\circledR}$ mounting medium (Vector Laboratories, Inc.). Immunofluorescence was then detected under a microscope with a band pass combination BP450-BP490 exciter filter, a diachroic chromatic beam splitter FT-510 filter, and a longwave pass LP-520 barrier filter.

\section{Microwave digestion and iron analysis of lyophilized protein}

Lyophilized glycoprotein from each treatment of sorghum and tall fescue was digested with concentrated nitric acid and analyzed for iron concentration. Briefly, approximately $1.0 \mathrm{mg}$ of sample was placed in a teflon tube with $3 \mathrm{ml}$ of concentrated nitric acid and $1 \mathrm{ml}$ of $\mathrm{dH}_{2} \mathrm{O}$. Tubes were sealed and placed in a microwave with a $10 \mathrm{~min} 100 \mathrm{psi}, 15 \mathrm{~min} 70 \mathrm{psi}$, and $10 \mathrm{~min}$ 50 psi cycle. The digested material was diluted to $25 \mathrm{ml}$ with distilled water and iron concentration was measured using atomic adsorption spectroscopy (AA). 


\section{Statistical Analysis}

Before analysis of variance (ANOVA) was performed, the Shapiro-Wilk test was used to check normal distribution, while Levene's test determined homogeneity of variance.

Appropriate transformations were performed when necessary. Pearson's partial correlations were plotted after data was grouped according to iron type, host, or treatment. All statistical tests were performed using $\mathrm{JMP}^{\circledR} 3.1$ or $\mathrm{SAS}^{\circledR}$ 7.0.

\section{RESULTS}

\section{Tests for contamination and nonspecific binding}

No plants in any pot cultures maintained in any of the three experiments were colonized by mycorrhizal fungi, and no spores were found. The potting media contained $18.5 \mu \mathrm{g} / \mathrm{g}$ of immunoreactive glomalin, which was extracted before use. Hematite amendments also did not contain any residual glomalin. An anti-Rhizobium IgM MAb substituted for MAb 32B11 did not bind with the glycoprotein in nonmycorrhizal cultures, excluding the possibility of nonspecific binding.

\section{Characteristics of the nonmycorrhizal glycoprotein}

The immunoreactive material produced in nonmycorrhizal cultures was verified to be a glycoprotein based on the Glycoprotein Carbohydrate Estimation Kit (Appendix D) and high heat-stability, evidenced by the lack of denaturation by the extraction procedure. SDS-PAGE gel and immuno-dot blot assays affirmed chemical behavior similar to that of glomalin. Microwave digestion of lyophilized glycoprotein extract indicated the presence of iron in the molecule, ranging from 0.02 to $0.27 \%$ (Table 1). Iron content was greater in molecules from pots amended with hematite than from FeEDDHA treatments for both host plants.

Glomalin preparation typically produces a doublet and a single band in the $90 \mathrm{KD}$ range (Wright et al., 1998) and extracts from hyphae of isolates from two AMF species, $G$. intraradices and Gi. rosea, produced identical bands (Fig. 1A and C). Concentrated glycoprotein from nonmycorrhizal pots collected after 8 weeks of plant growth produced a similar singlet and doublet of lower mobility than those of glomalin along with some heterogeneous bands that migrated to near the bottom of the lanes (Fig. 1B). Lyophilized glycoprotein collected from nonmycorrhizal pots after 3 months of plant growth produced a singlet and doublet in the same size range as glomalin along with a few faint bands, that migrated to near the bottom of some lanes (Fig. 1D).

The dot blot immunoassay was positive for nonmycorrhizal cultures, but the amount of immunoreactive material varied greatly among samples (Fig. 2A). Immunoreactivity also declined after boiling in SDS (Fig. 2A-B). The retentate fraction from Centricon ${ }^{\circledR} 50$ tubes contained immunoreactive glycoprotein, based on both ELISA $(0.0015 \pm 0.0003 \mu \mathrm{g} / \mu \mathrm{l})$ and immuno-dot blot assay (Fig. 2B). Total protein concentration in this fraction was $0.087 \mu \mathrm{g} / \mu \mathrm{l}$. 
The filtrate fraction collected from Centricon ${ }^{\circledR} 50$ tubes was not immunoreactive (Fig. 2A), but contained a total protein concentration of $0.013 \pm 0.002 \mu \mathrm{g} / \mu \mathrm{l}$.

Aseptate hyphae, extracted from some cultures, were thicker than AMF hyphae and also did not aggregate in a manner typical of AMF, suggesting they were from nonmycorrhizal fungi. No discernible immunofluorescence was seen when 56-day old sorghum roots were treated with anti-glomalin antibody for immunofluorescent material. In contrast, older (92-day old) roots of tall fescue produce strong immunofluorescence on their surfaces (Fig. 3).

The small amount of potting media sprinkled on nutrient agar plates produced numerous bacterial colonies and no fungal colonies. The bacteria were identified only to the genus Pseudomonas. None of these colonizes were immunoreactive with MAb 32B11.

\section{Glycoprotein accumulation by nonmycorrhizal sorghum}

The amount of glycoprotein extracted from the sand/root mixture in the potting medium differed significantly $(\mathrm{F}=0.0012)$ among iron treatments (Table 2). Cultures amended with $0.5 \%$ hematite at both $\mathrm{pH} 5.5$ and 8 were lowest in amount of glycoprotein produced. In contrast, glycoprotein was most abundant in cultures with the highest amendments of both iron sources at both $\mathrm{pHs}$. The $\mathrm{pH}$ of the potting medium did not appear to significantly affect glycoprotein accumulation (Table 3).

\section{Glycoprotein accumulation in nonmycorrhizal pots used to verify the absence of AMF}

Immunoreactive glycoprotein on roots of sudangrass manually removed from pot mix was low (averaging $\sim 0.016 \mathrm{mg} / \mathrm{g}$ ) at the 8 week sampling time, but reached concentrations of $0.6-3 \mathrm{mg} / \mu \mathrm{l}$ by 12 weeks. When roots were removed by forced water, glycoprotein concentrations could not be detected. To test the possibility that the glycoprotein was watersoluble or removed by rinsing and leached from pots, a water extraction was performed on random pot samples. Mean glycoprotein concentration in these extracts was $12.58 \pm 1.10 \mu \mathrm{g} / \mu \mathrm{l}$, although one sample measured $135.83 \mu \mathrm{g} / \mu \mathrm{l}$. When these samples were extracted again with citrate buffer, glycoprotein concentrations averaged $26.56 \pm 9.53 \mu \mathrm{g} / \mu \mathrm{l}$, with one sample measuring $169.93 \mu \mathrm{g} / \mu \mathrm{l}$.

\section{Glycoprotein concentrations in two nonmycorrhizal grasses}

Total protein and immunoreactive glycoprotein concentration in pot cultures of the two nonmycorrhizal grass species did not differ significantly among treatments, but was significantly greater for percentage immunoreactive glycoprotein in Tall fescue (Prob $>\mathrm{F}<0.0001)$. At the 56day sampling date, the glycoprotein concentrations in both iron-amended sorghum treatments were significantly lower than in the unamended treatments (Table 5). However, iron treatment did not significantly effect any of the glycoprotein measurements. Glycoprotein concentration increased significantly between 56 and 92 days $(\mathrm{F}=<0.001)$. The immunoreactive glycoprotein concentration was the highest for the no iron treatments for both sorghum and tall fescue after 92 days (Table 5). The percentage immunoreactive glycoprotein in tall fescue pots was at least 
twice that in sorghum pots, even though sorghum pots produced more glycoprotein overall (Table 5).

\section{Leaf chlorophyll content}

Leaves of sorghum and tall fescue were analyzed for chl a and chl b to estimate the effect of iron treatment on photosynthetic capacity. Chl a concentration was greater in sorghum $(221.19 \mu \mathrm{g} / \mathrm{g}$ compared to $158.16 \mu \mathrm{g} / \mathrm{g})$ while chl b concentration was significantly greater in tall fescue $(248.56 \mu \mathrm{g} / \mathrm{g}$ as opposed to $55.82 \mu \mathrm{g} / \mathrm{g})$. However, iron treatments did not significantly affect chlorophyll leaf content in either grass species, although chlorophyll concentrations appeared to be lowest in the $50 \mu \mathrm{M}$ FeEDDHA-amended pots (Table 4).

Interactions between various measures (i.e. glycoprotein concentration and chlorophyll analysis) were determined with Pearson's partial correlations calculated after grouping according to host, iron treatment, and host combined with iron treatment. Only highly significant correlations at $r>|0.8000|$ were examined (Table 6). Concentrations of chlorophyll $\mathrm{a}$ and $\mathrm{b}$ and of total and immunoreactive glycoprotein after 92 days plant growth frequently were positively correlated (Table 6).

\section{DISCUSSION}

The concentrations of glycoprotein produced in nonmycorrhizal pots during preliminary and first two experiments of this study varied considerably, ranging from 0.64 to $8.6 \mu \mathrm{g} / \mathrm{g}$ of sand in initial pot cultures and $0.6-3 \mathrm{mg} / \mathrm{g}$ in a second propagation cycle. In contrast, glomalin concentrations in mycorrhizal pots typically range from $1.7-15.5 \mathrm{mg}$ of total extracted protein (Wright unpubl.). Therefore, the concentration of glycoprotein in the nonmycorrhizal pots was 2-1000 fold less than that of glomalin in mycorrhizal cultures.

The possibility of contamination by external AMF first had to be eliminated as the source of immunoreactive glycoprotein. The long-term growth of plants in open greenhouse pots provides opportunity for contaminating fungal propagules to infect roots and establish low levels of mycorrhizal colonization (Morton et al., 1993). At low levels of colonization in these pots, sporulation often does not occur (Morton, unpubl.). In addition, some fungi in Glomus and Acaulospora produce only faintly staining mycorrhizae that often are not detected at low levels of colonization (Adelman and Morton, 1986; Morton, 1988). Reseeding of pot cultures to initiate a second propagation cycle for any fungi present often results in increased colonization and sporulation to detectable levels (Stutz and Morton, 1996). Pots from all experiments showed no evidence of mycorrhizal colonization or sporulation either in the initial culture cycle or in a second propagation cycle. The absence of color reaction when an anti-Rhizobium antibody was substituted for MAb 32B11 excluded the possibility of nonspecific binding in ELISA. Immunodot blot assays positive for the nonmycorrhizal samples (Fig. 2A-2D), also proved that immunoreactivity in ELISA plates was true cross-reactivity rather than a spurious reaction.

As a result of the above mentioned assays, I conclude that a molecule was being produced in cultures of nonmycorrhizal plants with a number of similarities to glomalin. First, 
the molecule was cross-reactive with MAb 32B11, indicating that tertiary and quaternary structure was similar enough to provide binding sites for the antibody. Similarity in structure also was evidenced by similar responses to SDS treatment (Fig. 2), in which the extent of denaturation varied considerably but was probably more dependent on initial glycoprotein concentration. Inability to stain with Coomassie Blue and obtain a Western blot indicates a glycoprotein whose carbohydrate chains inhibit the binding of SDS. As a result, denaturation is inhibited and molecules migrate more slowly (Carlsson, 1993). High carbohydrate concentration in the glycoprotein also results in weak staining with Coomassie Blue. Because of conformational changes that the glycosyl groups can undergo, binding to antibodies after transfer from the gel onto nitrocellulose does not occur to a high degree, making a Western blot unsuccessful (Carlsson, 1993). Second, the glycoprotein also was heat stable following an

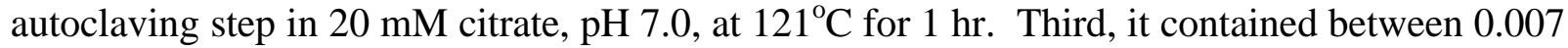
and $0.27 \%$ iron. Glomalin also contains iron, which also varies considerably with the environment in which it is formed (Wright and Anderson, 1999 and Wright, unpubl.).

The glycoprotein produced in nonmycorrhizal cultures, however, exhibits unique features that indicate it is not glomalin. Most strikingly, the amount produced in cultures is in microgram rather than milligram quantities (Wright et al., 1996). The amount of iron in the molecule is at least an order of magnitude less than that of glomalin (Wright and Anderson, 1999). The molecule also does not migrate to exactly the same position in SDS-PAGE gels, yet bands formed by glomalin consistently are positioned identically in all samples examined to date, whether from hyphae or from soil (Fig. 1, Wright, unpubl.). The banding patterns also indicate that the glycoprotein extracted from nonmycorrhizal cultures most likely consists of several molecules of slightly different structure or configuration. Proteinaceous molecules were found in both the retentate and filtrate fractions of Centricon ${ }^{\circledR} 50$ tubes based on positive reactions with

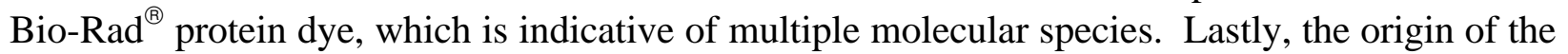
molecule is not hyphae of mycorrhizal fungi. No convincing evidence was produced in this study to indicate it originated from any other fungi that might become established in open pot cultures. Immunofluorescent assays, especially of nonmycorrhizal tall fescue roots, provide suggestive evidence that the glyoprotein is produced by the plant.

Glycoproteins are glycosylated proteins stabilized by their carbohydrate groups. This diverse family of macromolecules contains one or more heterosaccharides covalently bound to a polypeptide chain and are present in animals, plants, and microorganisms (Bahl, 1992). Glycoproteins vary greatly in structure and function with structural variations resulting from different degrees of gylcosylation and location of branching (Bahl, 1992; Ward et al., 1997; Wycoff et al., 1987). Carbohydrate structures may be altered during cellular growth, development, and differentiation, but these changes have not been demonstrated to alter their biological activity (Bahl, 1992; Ward et al., 1997). Since glycosyl groups are frequently found in abundance in glycoproteins, they often act as the antigen in antibody-binding.

Other glycoproteins produced by plants or other fungi may have a similar antibodybinding site as glomalin, since glycosyl groups can have homologous conformations. Large amounts of glycoproteins are produced in the cell wall of plants that help to protect the plant or to enhance root growth and structural stability (Taiz and Zeiger, 1991). These glycoproteins can be extracted by treatment with chelating agents, such as citric acid. Elicitors produced by 
pathogens which stimulate a defense response in plants also often are glycoproteins (Sacks et al., 1995, Sezalon-Delmas et al., 1997, Wycoff et al., 1987). These elicitors are frequently tightly associated with the cell wall, are heat and enzymatically stable, and their activity is not altered greatly even by conformational changes (Sacks et al., 1995).

Two environmental variables may have led to the production of stress-induced glycoproteins. Firstly, the plants were grown under relatively low light conditions ( 12\% of natural sunlight) (Taiz and Zeiger, 1991. Secondly, by using sand as the potting media and only watering once or twice a day, the plants were experienced nutrient deficiency and wet-dry cycles. As a result of low light intensity, especially in red spectra, root exudates promoting nutrient uptake and the growth of rhizosphere organisms likely were inhibited (Taiz and Zeiger, 1991). This would have contributed to nutrient deficiency.

Stress associated with low nutrients, especially iron, in the potting medium was likely to contribute to glycoprotein accumulation. Amendments of hematite, a plant-unavailable iron source, produced the greatest percentage of iron in the glycoprotein molecule (Table 1). Moreover, immunoreactive glycoprotein was produced in the greatest amounts in pots with no iron or low iron treatments (Table 5). The lower percentage immunoreactive glycoprotein in sorghum may have been caused by a reduction in immunoreactivity with sloughing. The less immunoreactive material on the sorghum roots compared to tall fescue (Fig. 3) exhibits this reduction in immunoreactivity.

Plants respond to iron stress by acidifying the rhizosphere or by excreting siderophores or ferredoxins that reduce iron making it more soluble and available. However, phytosiderophores are large molecules that have a low chelation rate and high carbon cost, whereas microbial siderophores are more efficient (Lucena et al., 1990; Crowley et al., 1992). Production of siderophores can also help in the acquisition of phosphorus since iron chelation will cause iron phosphates to release the phosphorus (Torrent et al., 1994; Guzman et al., 1994). When both P and iron are limited and plants are nonmycorrhizal, these plants may produce exudates to acquire as many of these nutrients as possible. Exudates of carbohydrates, carboxylic acids, and amino acids are significantly reduced with an increase in phosphorus, because of a reduction in membrane permeability (Schwab et al., 1983). Root leakage also has been correlated with variation in light intensity, photoperiod, temperature, stage of plant development, and exposure to ozone stress (Schwab et al., 1984). Ferguson and Menge (1982) found that plant root exudation of sugars increases with increasing PAR (photosynthetically active radiation).

Sorghum (a C4 grass) uses two organelles to conduct photosyntheisis (mesophyll and bundle sheath cells). Because compounds must be transferred between these two organelles, C4 plants require more energy than $\mathrm{C} 3$ plants. Photosynthesis in $\mathrm{C} 4$ plants becomes saturated at PAR levels of $50-80 \%\left(1000-1600 \mu \mathrm{mol} \mathrm{m}^{-2} \mathrm{~s}^{-1}\right)$ of that of full sunlight (Ferguson and Menge, 1982), but C3 plants require less light. Along with a higher energy requirement, C4 plants also need more iron (Marschner, 1995). However, compared to other grasses, sorghum has a low production of phytosiderophores to accumulate this iron. This grass uses other mechanisms, such as acidifying the rhizosphere or releasing other proteins, to help in iron accumulation. The low percentage immunoreactive protein in sorghum could also be due to the production of these 
other proteins that are not immunoreactive but are measured with the non-specific total protein assay.

Glomalin is associated with all species of AMF tested to date (Wright et al., 1996). The two suborders of AMF, Glomineae and Gigasporineae, share similar symbiotic functions but differ greatly in development, morphology, biochemical structure of cell walls, and types of infective propagules (Morton, 1999). Each of these lineages is hypothesized to have evolved independently, and many design constraints on fungal cell structure and function in the symbiosis (Smith and Gianinazzi-Pearson, 1988) increase the possibility of convergent evolution. Even ultrastructural and cytochemical properties of the symbiotic interface between fungus/cyanbacterium in the Geosiphon symbiosis and the arbuscule/root-cell in AM share many features (Gehrig et al., 1996). Similar convergent evolution may have occurred in the production of glomalin molecules by fungi in each suborder. Glomalin is found in both AMF orders, but some variation in glomalin structure has been identified. HPCE (high performance capillary electrophoresis) revealed that glomalin appears to have five to nine carbohydrate units. Also, hyphal and soil samples were alike in that all had a major oligosaccharide, but these oligosaccharides were different. Some soil samples also contained oligosaccharides with longer carbohydrate chains than hyphal samples (Wright et al., 1998).

MAb 32B11 does not react with non-AMF hyphae in tests conducted thus far (Wright $e t$ al., 1996). Cross-reactivity of MAb 32B11 with glomalin and the glycoprotein from nonmycorrhizal plants suggests convergent evolution of molecules with similar structure and function in both phytobiont and mycobiont in the arbuscular mycorrhizal association. Cress et al. (1986) found a protein coating mycorrhizal AMF hyphae that had properties of a siderophore. Its location and function suggest that it is glomalin. Siderophores are high-affinity iron chelators, which are synthesized and secreted under iron deficiency. They bind to iron and transport it into the cell via a membrane ionophore that transports the whole molecule into the cell or via release of iron at cell surface followed by transport inside the cell (Payne, 1994 and Winklemann, 1992). These molecules (produced by many other macro- and microorganisms) share some structural similarities that could extend to antibody-binding sites.

One of the difficulties in obtaining a clear understanding of the location and abundance of glycoprotein accumulation by nonmycorrhizal plants may be the potential for water to solubilize or wash away the molecule. Washed roots or nonmycorrhizal fungal hyphae often produced negative results in immunoassays, despite the clear presence of the glycoprotein in situ in potting media. Differences in hosts, either as a result of their physiology or other variables such as root structure, also appear to affect the glycoprotein. Immunofluorescent glycoprotein on sorghum roots was spotty, whereas it was more clearly evident on tall fescue roots (Fig. 3). The occurrence of immunofluorescent material on these samples, but not earlier samples may be a function of the structural state of the glycoprotein at different times during plant development. The amount of glycoprotein was less in early samples from nonmycorrhizal pots, suggesting that it may take time to build up the concentration of protein.

Other fungi were found in the nonmycorrhizal pot cultures, as evidenced by the presence of unaggregating hyphae in potting media extracts. Occurrence of such saprophytic fungi in pot cultures is a normal consequence of long-term culture maintenance using a non-sterile water 
source (Morton, unpubl.). These fungi were not be cultured on nutrient agar plates and the bacteria that were cultured did not produce an immunoreactive glycoprotein. Glycoproteins are not frequently produced by bacteria, so this result was not unexpected. A water-soluble glycoprotein would not likely be retained on fungal hyphae after extensive manipulation, so the possibility of nonmycorrhizal fungi contributing to glycoprotein accumulation cannot be completely ruled out. Many fungi are able to synthesize hydroxamate siderophores, which are highly stable in their ferric-hydroxamate complexes. Configuration and stereochemical specificity is important in transport processes into the cell and the number and kinds of N-acyl groups surrounding the metal center can have an adverse effect on uptake (Winkelmann, 1992). Because of this specificity, some of the groups will have a similar conformation that can also act as the antibody-binding site. Ectomycorrhizal fungi produce hydroxymate siderophores that mobilize iron in the vicinity of hyphae with a greater affinity than chelators produced by the root (Szaniszlo et al., 1981). Iron uptake by a specific type of iron entrapment also has been seen in ericoid mycorrhizae (Shaw et al., 1990). However, the high degree of specificity between MAb32B11 and the glycoprotein produced on the hyphae of only glomalean fungi (Wright et al., 1996), together with the unique evolutionary history of this group (Morton, 1999), supports the hypothesis that it is more likely the plant which is the source of the glycoprotein.

This study establishes that a cross-reactive glycoprotein is produced in nonmycorrhizal pots under the conditions of the experiments conducted in our greenhouse. To understand the true relationship between this glycoprotein and glomalin, additional studies are needed on these glycoprotiens and plants grown under typical growing conditions. Use of the glycoprotein as immunogen to produce new monoclonal antibodies are likely to further clarify affinities with glomalin and when and where this nonmycorrhizal glycoprotein is produced.

\section{LITERATURE CITED}

Adelman, M.J. and J.B. Morton. 1986. Infectivity of vesicular-arbuscular mycorrhizal fungi: influence of host-soil diluent combinations on MPN estimates and percentage colonization. Soil Biology and Biochemistry 18:77-83.

Bahl, O.P. 1992. An introduction in glycoproteins. In: Glycoconjugates: Composition, Structure and Function. Eds. H.J. Allen and C. Kisalius. Marcel Dekker Inc. New York, USA. 112.

Bentivenga, S.P., and J.B. Morton. 1996. Congruence of fatty acid methyl ester profiles and morphological characters of arbuscular mycorrhizal fungi in Gigasporaceae. Proceedings of the National Academy of Sciences 93:5659-5662.

Bolan, N.S. 1991. A critical review on the role of mycorrhizal fungi in the uptake of phosphorus by plants. Plant and Soil 134:189-207.

Bolan, M.S., A.D. Robson, and N.J. Barrow. 1987. Effects of vesicular-arbuscular mycorrhiza on the availability of iron phosphates to plants. Plant and Soil 99:401-410.

Bradford, M.M. 1976. A rapid and sensitive method for the quanitation of microgram quantities of protein utilizing the principle of protein-dye binding. Analytical Biochemistry 72:248254.

Carlsson S.R. 1993. Isolation and characterization of glycoproteins. In: Glycobiolory: A practical Approach. Eds. M. Fukuda and A. Kobata IRL Press. Oxford, UK. 1-26. 
Cress, W.A., G.V. Johnson, and L.L. Barton. 1986. The role of endomycorrhizal fungi in iron uptake by Hilaria Jamesii. Journal of Plant Nutrition 9:547-556.

Crowley, D.E., V. Romheld, H. Marschner, and P.J. Szaniszlo. 1992. Root-microbial effects on plant iron uptake form siderophores and phytosiderophores. Plant and Soil 142:1-7.

Ferguson, J.J. and J.A. Menge. 1982. The influence of light intensity and artifically extended photoperiod upon infection and sporulation of Glomus fasciculatus on sudan grass and on root exudation of sudan grass. New Phytologist 92:183-191.

Gehrig, H., A. Schubler, and M. Kluge. 1996. Geosiphon pyriforme, a fungus forming endocytobiosis with Nostoc (Cyanobacteria), is an ancestral member of the Glomales: Evidence by SSU rRNA analysis. Journal of Molecular Evolution 43:71-81.

Giovannetti, M., and B. Mosse. 1980. An evaluation of techniques for measuring vesicular arbuscular mycorrhizal infection in roots. New Phytologist 84:489-500.

Green, J.R. N.A. Pain, M.E. Cannell, G.L. Jones, C.P. Leckie, S. McCready, K. Mendgen, A.J. Mitchell, J.A. Callow, and R.J. O'Connell. 1995. Analysis of differentiation and development of the specialized infection structures formed by biotrophic fungal plant pathogens using monoclonal antibodies. Canadian Jounal of Botany 73:S408-S417.

Guzman, G., E. Alcantara, V. Barron, and J. Torrent. 1994. Phytoavailability of phosphate absorbed on ferrihydrite, hematite, and geothite. Plant and Soil 159:219-225.

Hetrick, B.A.D. 1991. Mycorrhizas and root architecture. Experientia 47:355-362.

Lucena, J.J., A. Garate, A.M. Ramon, and M. Manzanares. 1990. Iron nutrition of a hydroponic strawberry culture (Fragaria vesca L.) supplied with different Fe chelates. Plant and Soil 123:9-15.

Jayachandran, K., A.P. Schwab, and B.A.D. Hetrick. 1989. Mycorrhizal mediation of phosphorus availability: Synthetic iron chelate effects on phosphorus solubilization. Soil Science Society of America Journal 53:1701-1706.

Morton, J.B., and S.P. Bentivenga. 1994. Levels of diversity in endomycorrhizal fungi (Glomales, Zygomycetes) and their role in defining taxonomic and non-taxonomic groups. Plant and Soil 159:47-59.

Morton, J.B. 1988. Taxonomy of VA mycorrhizal fungi: classification, nomenclature, and identification. Mycotaxon 32:267-324.

Morton, J.B. 1999. Evolution of endophytism in arbuscular mycorrhizal fungi of Glomales. In: Microbial Endophytes. Eds. C.W. Bacon and J.F. White. 121-140. Marcel Dekker, Inc., New York.

Morton, J.B., S.P. Bentivenga, W.W. Wheeler. 1993. Germ plasm in the International Collection of Arbuscular and Vesicular-arbucular Mycorrhizal Fungi (INVAM) and procedures for culture development, documentation and storage. Mycotaxon 158:491528.

Payne, S.M. 1994. Detection, isolation, and characterization of siderophores. Methods in Enzymology 235:329-344.

Phillips, J.M. and D.S. Hayman. 1970. Improved procedures for clearing roots and staining parasitic and vesicular-arbuscular fungi for rapid assessment of infection. Transactions of the British Mycological Society 55:158-161.

Porra, R.L., W.A. Thompson, and P.E. Kreidemann. 1989. Determination of accurate extinction coefficients and simultaneous equations for assaying chlorophylls $a$ and $b$ extracted with four different solvents: verification of the concentration of chlorophyll standards by atomic adsorption spectroscopy. Biochimica et Biophysica Acta 975:384-394. 
Sacks, W., T. Nürnberger, K. Hahlbrock, and D. Scheel. 1995. Molecular characterization of nucleotide sequences encoding the extracellular glycoprotein elicitor from Phytophthora megasperma. Molecular and General Genetics 246:45-55.

Schwab, S.M., R.T. Leonard, and J.A. Menge. 1984. Quantitative and qualitative comparison of root exudates of mycorrhizal and nonmycorrhizal plant species. Canadian Journal of Botany 62:1227-1231.

Schwab, S.M., J.A. Menge, and R.T. Leonard. 1983. Quantitative and qualitative effects of phosphorus on extracts and exudates of sudangrass roots in relation to vesiculararbuscular mycorrhiza formation. Plant Physiology 73:761-765.

Sejalon-Delmas, N., F. Villalba Mateos, A. Bottin, M. Rickauer, R. Dargent, and M.T. EsquerreTugaye. 1997. Purification, elicitor activity, and cell wall localization of a glycoprotein from Phytophthora parasitica var. nicotianae, a fungal pathogen of tobacco. Biochemistry and Cell Biology 87:899-909.

Shaw, G., J.R. Leake, A.J.M. Baker, and D.J. Read. 1990. The biology of mycorrhiza in the Ericaceae XVII. The role of mycorrhizal infection in the regulation of iron uptake by ericaceous plants. New Phytologist 115:251-258.

Smith, S. and V. Gianinazzi-Pearson. 1988. Physiological interactions between symbionts in vesicular-arbuscular mycorrhizal plants. Annual review of plant physiology and plant molecular biology 39:221-244.

Stutz, J.C. and J.B. Morton. 1996. Successive pot cultures reveal high species richness of arbuscular endomycorrhizal fungi in arid ecosystems. Canadian Journal of Botany 74:1883-1889.

Szaniszlo, P.J., P.E. Powell, C.P.P. Reid, and G.R. Cline. 1981. Production of hydroxamate siderophore iron chelators by ectomycorrhizal fungi. Mycologia 73: 1158-1174.

Taiz, L. and E. Zeiger. 1991. Plant Physiology. The Benjamin/Cummings Publishing Company, Inc. p. 22.

Torrent, J., U. Schwertmann, and V. Barron. 1994. Phosphate sorption by natural hematites. European Journal of Soil Science 45:45-51.

Ward, P.P., G.A. Cunningham, and O.M. Conneely. 1997. Commerical production of lactoferrin, a multifunctional iron-binding glycoprotein. Biotechnology and Genetic Engineering Reviews 14:303-319.

Winkelman, G. 1992. Structures and fuctions of fungal siderophores containing hydroxamate and complexone type iron binding ligands. Mycology Reviews 96:529-534.

Wright, S.F. and R.L. Anderson. 1999. Aggregate stability and glomalin in alternative crop rotations for the Central Great Plains. Biology and Fertility of Soils (In Press).

Wright, S.F., M. Franke-Snyder, J.B. Morton, and A. Upadhyaya. 1996. Time-course study and partial characterization of a protein on arbuscular mycorrhizal hyphae during active colonization of roots. Plant and Soil 181:193-203.

Wright, S.F. and J.B. Morton. 1989. Detection of vesicular-arbuscular mycorrhizal fungus colonization of roots by using a Dot-immunoblot assay. Applied and Environmental Microbiology. 55:761-763.

Wright, S.F., J.B. Morton, and J.E. Sworobuk. 1987. Identification of a vesicular-arbuscular mycorrhizal fungus by using monoclonal antibodies in an enzyme-linked immunosorbent assay. Applied and Environmental Microbiology 53:2222-2225. 
Wright, S.F. and A. Upadhyaya. 1996. Extraction of an abundant and unusual protein from soil and comparison with hyphal protein of arbuscular mycorrhizal fungi. Soil Science 161:575-586.

Wright, S.F. and A. Upadhyaya. 1998. A survey of soils for aggregate stability and glomalin, a glycoprotein produced by hyphae of arbuscular mycorrhizal fungi. Plant and Soil 198:97107.

Wright, S.F. and Upadhyaya, A. 1999. Quantification of arbuscular mycorrhizal fungi activity by the glomalin concentration on hyphal traps. Mycorrhiza 8:283-285.

Wright, S.F., A. Upadhyaya, and J.S. Buyer. 1998. Comparison of N-linked oligosaccharides of glomalin from arbuscular mycorrhizal fungi and soils by capillary electorphoresis. Soil Biology and Biochemistry 30:1853-1857.

Wycoff, K.L., J. Jellison, and A.R. Ayers. 1987. Monoclonal antibodies to glycoprotein antigens of a fungal plant pathogen, Phytophthora megasperma f. sp. glycinea. Plant Physiology 85:508-515.

Xia, J.Q., F.N. Lee, and K.S. Kim. 1992. Monoclonal antibodies to an extracellular component of Pyricularia grisea. Canadian Journal of Botany 70:1790-1797. 
Table 1. Percentage iron in the cross-reactive glycoprotein molecule from iron-amended pot contents in which nonmycorrhizal sorghum and tall fescue were grown for 92 days.

\begin{tabular}{|c|c|c|c|}
\hline \multirow{3}{*}{ Host plant } & Iron type & Iron concentration & $\% \mathrm{Fe}$ \\
\hline \multirow{3}{*}{ Sorghum } & \multirow{2}{*}{ FeEDDHA } & $0 \mathrm{M}$ & 0.000 \\
\cline { 2 - 4 } & & $50 \mathrm{M}$ & 0.020 \\
\cline { 2 - 4 } & Hematite & $1.50 \%$ & 0.054 \\
\hline \multirow{3}{*}{ Fescue } & FeEDDHA & $0 \mathrm{M}$ & 0.007 \\
\cline { 2 - 4 } & & $50 \mathrm{M}$ & 0.025 \\
\cline { 2 - 4 } & Hematite & $1.50 \%$ & 0.266 \\
\hline
\end{tabular}


Table 2. Immunoreactive glycoprotein concentration $(\mu \mathrm{g} / \mathrm{g})$ in a potting media/root subsample from nonmycorrhizal sorghum grown in sand amended with two iron sources at two $\mathrm{pH}$ levels.

\begin{tabular}{|c|c|c|c|}
\hline $\mathrm{pH}$ & Iron species & $\begin{array}{c}\text { Iron } \\
\text { concentration }\end{array}$ & $\begin{array}{c}\text { Immunoreactive } \\
\text { glycoprotein } \\
(\mu \mathrm{g} / \mathrm{g})\end{array}$ \\
\hline \multirow{5}{*}{5.5} & \multirow{3}{*}{ FeEDDHA } & $0 \mu \mathrm{M}$ & $1.10 \pm 0.25^{b c}$ \\
\hline & & $25 \mu \mathrm{M}$ & $3.21 \pm 1.56^{\mathrm{ab}}$ \\
\hline & & $50 \mu \mathrm{M}$ & $3.97 \pm 1.53^{\mathrm{a}}$ \\
\hline & \multirow{2}{*}{ Hematite } & $0.50 \%$ & $0.64 \pm 0.26^{c}$ \\
\hline & & $1.50 \%$ & $5.63 \pm 0.08^{\mathrm{a}}$ \\
\hline \multirow{6}{*}{8} & \multirow{3}{*}{ FeEDDHA } & $0 \mu \mathrm{M}$ & $2.72 \pm 0.53^{\mathrm{ab}}$ \\
\hline & & $25 \mu \mathrm{M}$ & $3.59 \pm 1.17^{\mathrm{a}}$ \\
\hline & & $50 \mu \mathrm{M}$ & $3.85 \pm 0.24^{\mathrm{a}}$ \\
\hline & \multirow{2}{*}{ Hematite } & $0.50 \%$ & $0.69 \pm 0.26^{c}$ \\
\hline & & $1.50 \%$ & $4.59 \pm 1.35^{\mathrm{a}}$ \\
\hline & & Prob $>F$ & 0.0012 \\
\hline
\end{tabular}

*Values followed by the same letter in the same column are not significantly different at 0.05 . 
Table 3. Effects of $\mathrm{pH}$ and iron levels on concentration of an immunoreactive glycoprotein extracted from potting medium of nonmycorrhizal sorghum.

\begin{tabular}{|c|c|c|}
\hline \multirow{2}{*}{$\mathrm{pH}$ level } & 5.5 & $\begin{array}{c}\text { Immunoreactive } \\
\text { glycoprotein } \\
(\mu \mathrm{g} / \mathrm{g})^{*}\end{array}$ \\
\hline \multirow{3}{*}{ Iron species } & 8 & $2.91 \pm 0.62^{\mathrm{a}}$ \\
& Prob< $|\mathrm{t}|$ & $3.09 \pm 0.48^{\mathrm{a}}$ \\
& $0 \mu \mathrm{M} \mathrm{FeEDDHA}$ & 0.5572 \\
\hline & $25 \mu \mathrm{M}$ FeEDDHA & $1.91 \pm 0.45^{\mathrm{b}}$ \\
& $50 \mu \mathrm{M}$ FeEDDHA & $3.40 \pm 0.88^{\mathrm{ab}}$ \\
& $0.5 \%$ hematite & $0.67 \pm 0.19^{\mathrm{c}}$ \\
& $1.5 \%$ hematite & $5.11 \pm 0.65^{\mathrm{a}}$ \\
& Prob $>\mathrm{F}$ & $<0.0001$ \\
\hline
\end{tabular}

*Values followed by the same letter in the same column are not significantly different at 0.05 . 
Table 4. Chlorophyll a and b concentration ( $\mu \mathrm{g} / \mathrm{g}$ of dry plant tissue) in foliar tissue of nonmycorrhizal sorghum and tall fescue grown in sand at different concentrations of FeEDDHA and hematite.

\begin{tabular}{|ccccc|}
\hline Host plant & Iron type & $\begin{array}{c}\text { Iron } \\
\text { concentration }\end{array}$ & $\begin{array}{c}\text { chl a } \\
\text { concentration } \\
(\mu \mathrm{g} / \mathrm{g})\end{array}$ & $\begin{array}{c}\text { chl b } \\
\text { concentration } \\
(\mu \mathrm{g} / \mathrm{g})\end{array}$ \\
\hline \multirow{3}{*}{ Sorghum } & FeEDDHA & $0 \mu \mathrm{M}$ & $257.27 \pm 18.03^{\mathrm{a}}$ & $64.20 \pm 4.53^{\mathrm{a}}$ \\
& & $50 \mu \mathrm{M}$ & $175.99 \pm 36.18^{\mathrm{a}}$ & $48.77 \pm 11.08^{\mathrm{a}}$ \\
\cline { 2 - 5 } & Hematite & $1.50 \%$ & $233.31 \pm 44.41^{\mathrm{a}}$ & $54.50 \pm 9.59^{\mathrm{a}}$ \\
\cline { 2 - 5 } Fescue & Prob $>\mathrm{F}$ & & 0.2843 & 0.4884 \\
\hline \multirow{3}{*}{ FeEDDHA } & $0 \mu \mathrm{M}$ & $235.61 \pm 148.93^{\mathrm{A}}$ & $371.24 \pm 199.20^{\mathrm{A}}$ \\
\cline { 2 - 5 } & Hematite & $1.50 \%$ & $123.20 \pm 8.03^{\mathrm{A}}$ & $182.13 \pm 25.59^{\mathrm{A}}$ \\
\hline & Prob $>\mathrm{F}$ & & 0.5215 & 0.5086 \\
\hline
\end{tabular}

*Values followed by the same letter in the same column are not significantly different at 0.05 . 
Table 5. Immunoreactive and total protein concentration $(\mu \mathrm{g} / \mathrm{g})$ of nonmycorrhizal sorghum and tall fescue grown in sand with different concentrations of FeEDDHA and hematite at two sampling dates.

\begin{tabular}{|c|c|c|c|c|c|c|}
\hline \multirow{2}{*}{$\begin{array}{c}\text { Host } \\
\text { plant } \\
\text { Sorghum }\end{array}$} & \multicolumn{2}{|c|}{ Iron source } & \multirow{2}{*}{$\begin{array}{c}\begin{array}{c}\text { Immuno- } \\
\text { reactive } \\
\text { glycoprotein } \\
\text { at } 56 \text { days }\end{array} \\
13.45 \pm 1.89^{\mathrm{a}} \\
7.61 \pm 1.39^{\mathrm{b}}\end{array}$} & \multirow{2}{*}{\begin{tabular}{|c} 
Total protein at \\
92 days
\end{tabular}} & \multicolumn{2}{|c|}{$\begin{array}{c}\text { Immunoreactive glycoprotein } \\
\text { at } 92 \text { days }\end{array}$} \\
\hline & FeEDDHA & $\begin{array}{l}0 \mu \mathrm{M} \\
50 \mu \mathrm{M}\end{array}$ & & & $\begin{array}{c}262.93 \pm 18.60^{\mathrm{a}} \\
49.27 \pm 6.60^{\mathrm{b}}\end{array}$ & $\begin{array}{l}5.01 \pm 0.48^{\mathrm{a}} \\
6.23 \pm 0.82^{\mathrm{a}}\end{array}$ \\
\hline & Hematite & $1.50 \%$ & $7.21 \pm 0.55^{b}$ & $1978.80 \pm 739.27^{\mathrm{a}}$ & $79.54 \pm 19.57^{b}$ & $4.91 \pm 1.26^{\mathrm{a}}$ \\
\hline & Prob $>F$ & & 0.0194 & 0.5900 & $<0.0001$ & 0.5446 \\
\hline Fescue & FeEDDHA & $\begin{array}{l}0 \mu \mathrm{M} \\
50 \mu \mathrm{M}\end{array}$ & $\begin{array}{l}12.14 \pm 1.46^{\mathrm{A}} \\
13.70 \pm 0.32^{\mathrm{A}}\end{array}$ & $\begin{array}{c}806.48 \pm 388.14^{\mathrm{A}} \\
514.75 \pm 71.15^{\mathrm{A}}\end{array}$ & $\begin{array}{r}112.43 \pm 27.55^{\mathrm{A}} \\
69.78 \pm 13.89^{\mathrm{A}}\end{array}$ & $\begin{array}{l}17.74 \pm 2.93^{\mathrm{A}} \\
13.44 \pm 0.84^{\mathrm{A}}\end{array}$ \\
\hline & Hematite & $1.50 \%$ & $11.23 \pm 0.59^{\mathrm{A}}$ & $386.60 \pm 98.68^{\mathrm{A}}$ & $63.55 \pm 14.60^{\mathrm{A}}$ & $17.07 \pm 1.38^{\mathrm{A}}$ \\
\hline & Prob $>F$ & & 0.2635 & 0.5487 & 0.2788 & 0.5215 \\
\hline
\end{tabular}

*Values followed by the same letter in the same column are not significantly different at 0.05 . 
Table 6. The most strongly correlated $(r>|0.8000|)$ interactions for nonmycorrhizal sorghum and tall fescue grouped by host, iron treatment $(0=$ no iron, $1.5=1.5 \%$ hematite, and $50=50$ $\mu \mathrm{M}$ FeEDDHA), and host by iron treatment interaction (grouping variable in parentheses).

\begin{tabular}{|c|c|c|c|c|c|}
\hline Variables & $\begin{array}{l}\text { Chlorophyll } \\
\text { b }\end{array}$ & $\begin{array}{l}\text { Immuno- } \\
\text { reactive } \\
\text { protein after } \\
56 \text { days }\end{array}$ & $\begin{array}{l}\text { Total protein } \\
\text { after } 92 \text { days }\end{array}$ & $\begin{array}{l}\text { Immuno- } \\
\text { reactive } \\
\text { protein after } \\
92 \text { days }\end{array}$ & $\begin{array}{l}\text { \% Immuno- } \\
\text { reactive } \\
\text { protein after } \\
92 \text { days }\end{array}$ \\
\hline Chlorophyll a & $\begin{array}{c}0.9197 * * * \\
\text { (fescue) } \\
0.9475^{*} * * \\
\text { (sorghum) } \\
0.9714^{*} \\
(0 \text { fescue) } \\
0.9829^{*} \\
(0 \text { sorghum) } \\
0.9927 * * \\
(1.5 \\
\text { sorghum) } \\
0.9525^{*} \\
(50 \text { sorghum) }\end{array}$ & $\begin{array}{c}0.9514^{*} \\
(1.5 \text { fescue }) \\
-0.9580^{*} \\
(50 \text { fescue })\end{array}$ & $\begin{array}{c}0.9890^{* * *} \\
\text { (1.5\% iron) } \\
0.9995^{* * * *} \\
(1.5 \\
\text { sorghum) }\end{array}$ & & $\begin{array}{l}-0.96653^{*} \\
\text { (50 fescue) }\end{array}$ \\
\hline Chlorophyll b & & $\begin{array}{c}0.8967 * * \\
\text { (1.5\% iron) }\end{array}$ & $\begin{array}{c}-0.9855^{* *} \\
\text { (50 fescue) } \\
0.9900^{* *} \\
(1.5 \\
\text { sorghum) }\end{array}$ & $\begin{array}{l}-0.9830 * * \\
\text { (50 fescue) }\end{array}$ & \\
\hline $\begin{array}{l}\text { Immuno- } \\
\text { reactive } \\
\text { protein } \\
\text { concentration } \\
\text { after } 56 \text { days }\end{array}$ & & & & & $\begin{array}{c}0.8412 * * \\
(1.5 \% \text { iron }) \\
0.9981 * * \\
(50 \text { fescue })\end{array}$ \\
\hline $\begin{array}{l}\text { Total protein } \\
\text { concentration } \\
\text { after } 92 \text { days }\end{array}$ & & & & $\begin{array}{c}0.9973 * * * \\
\text { (fescue) } \\
0.9216^{* * *} * \\
\text { (sorghum) } \\
0.9207 * * \\
\text { (No iron) } \\
0.9612^{*} \\
(0 \text { fescue) } \\
0.9892 * \\
(1.5 \text { fescue) } \\
0.9998^{*} * * \\
(50 \text { fescue) }\end{array}$ & $\begin{array}{c}-0.9389 * * * \\
\text { (No iron) }\end{array}$ \\
\hline $\begin{array}{c}\text { Immuno- } \\
\text { reactive } \\
\text { protein } \\
\text { concentration } \\
\text { after } 92 \text { days }\end{array}$ & & & & & $\begin{array}{l}-0.8877 * * \\
\text { (No iron) }\end{array}$ \\
\hline
\end{tabular}

$*, * *, * * *$ denote significance at the $5 \%, 1 \%$, and $0.1 \%$ levels, respectively 

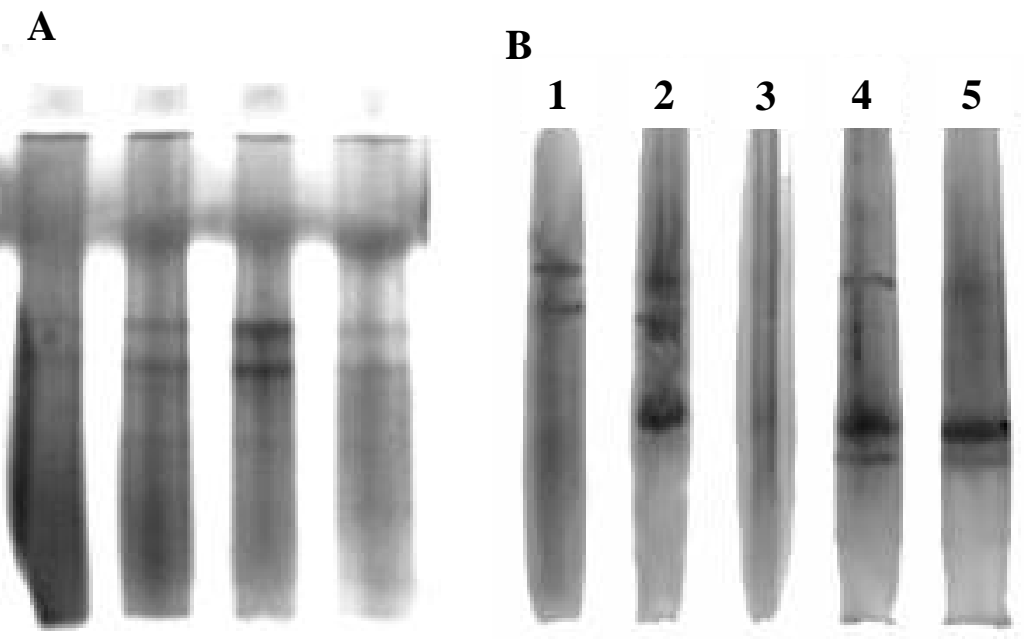

C

D
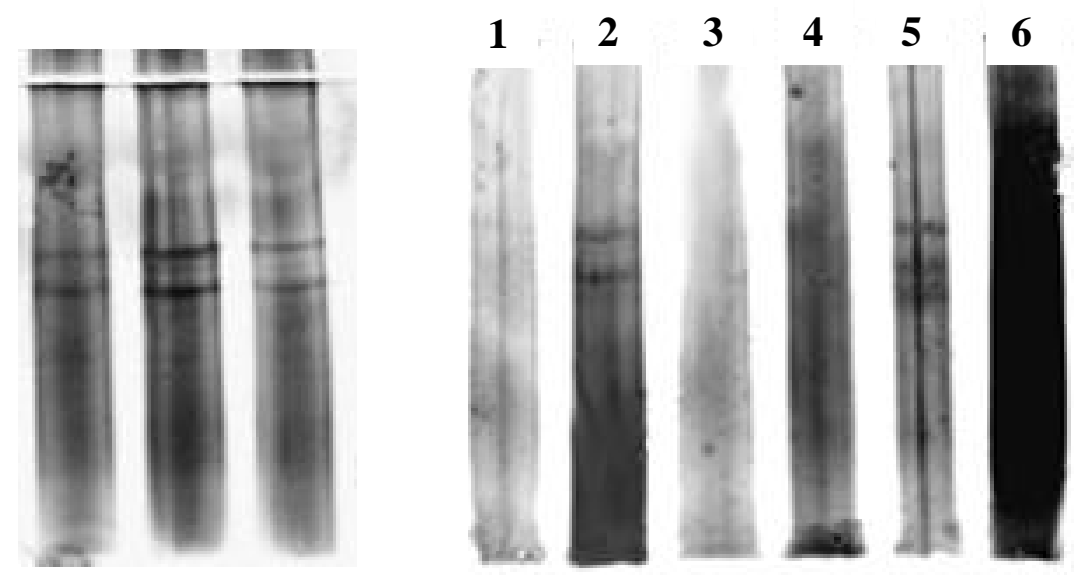

Figure 1. SDS-PAGE gels using the PhastSystem. A. Glomalin extracted from hyphae of Glomus intraradices. B. Glycoprotein extracted from potting media of 2-month-old nonmycorrhizal sorghum: (1) $0.5 \%$ hematite at pH 8.0, no iron at pH 8.0, (2) $25 \mu \mathrm{M}$ EDDHA at pH 5.5, (3) $1.5 \%$ hematite at pH 5.5, (4) $50 \mu \mathrm{M}$ EDDHA at pH 8.0, (5) 50 $\mu \mathrm{M}$ EDDHA at pH 5.5. C. Glomalin extracted from hyphae of Gigaspora rosea. D. Glycoprotein extracted from potting media of 3-month-old nonmycorrhizal plants reconstituted from lyophilized protein. 1-3. Sorghum: No iron, $50 \mu \mathrm{M}$ EDDHA, and 1.5\% hematite, respectively. 4-6. Fescue: No iron, $50 \mu \mathrm{M}$ EDDHA, and $1.5 \%$ hematite, respectively. 

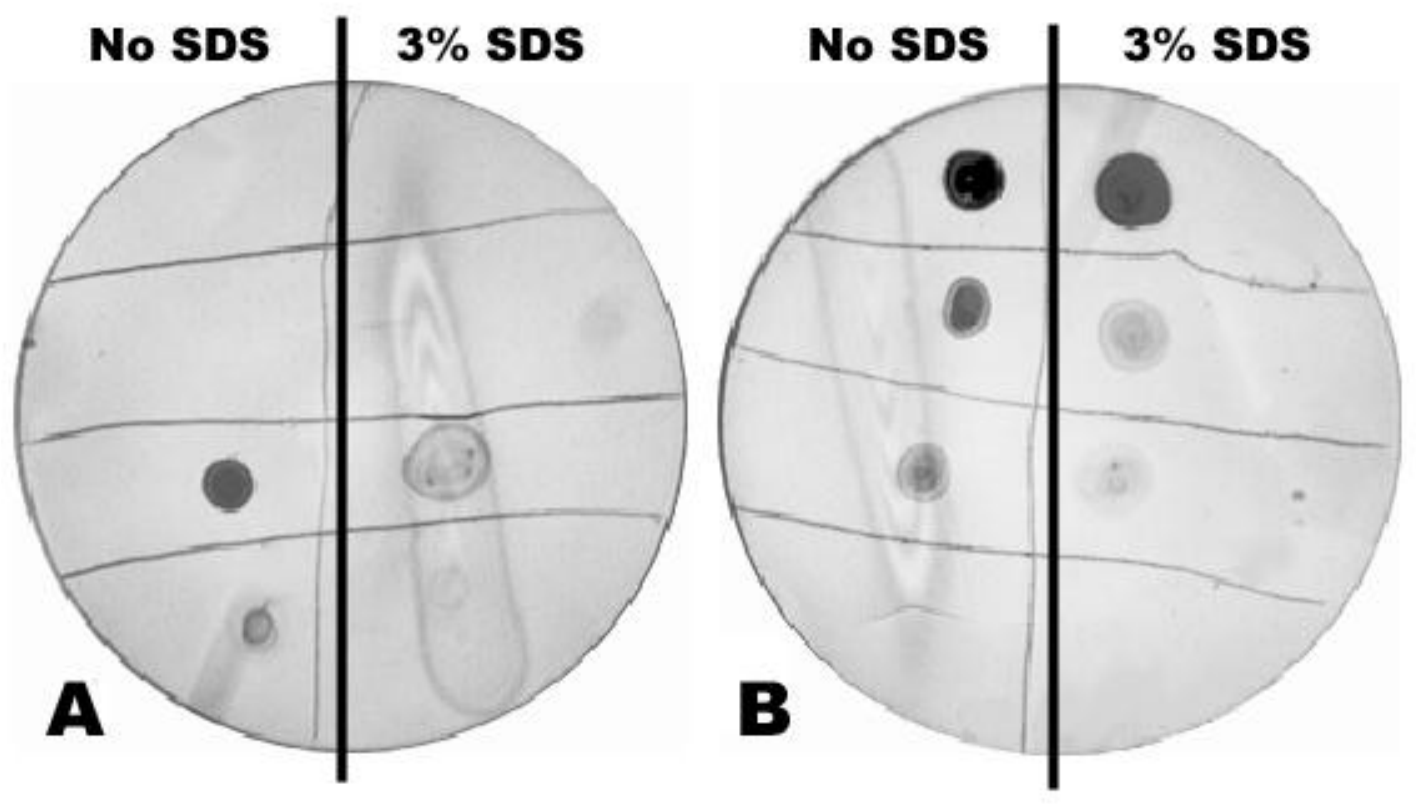

Figure 2. Immuno-dot blot assays of glomalin and glycoprotein from nonmycorrhizal pots untreated or boiled in 3\% SDS for $10 \mathrm{~min}$. A. Filtrate fraction from extracts of nonmycorrhizal pots passed through a Centricon ${ }^{\circledR} 50$ membrane filter (upper four grids) or unfiltered extracts (lower four grids). B. Retentate fraction from Centricon ${ }^{\circledR}$ 50 membrane filtration of extracts from mycorrhizal (top two grids) or nonmycorrhizal pots (lower six grids). 

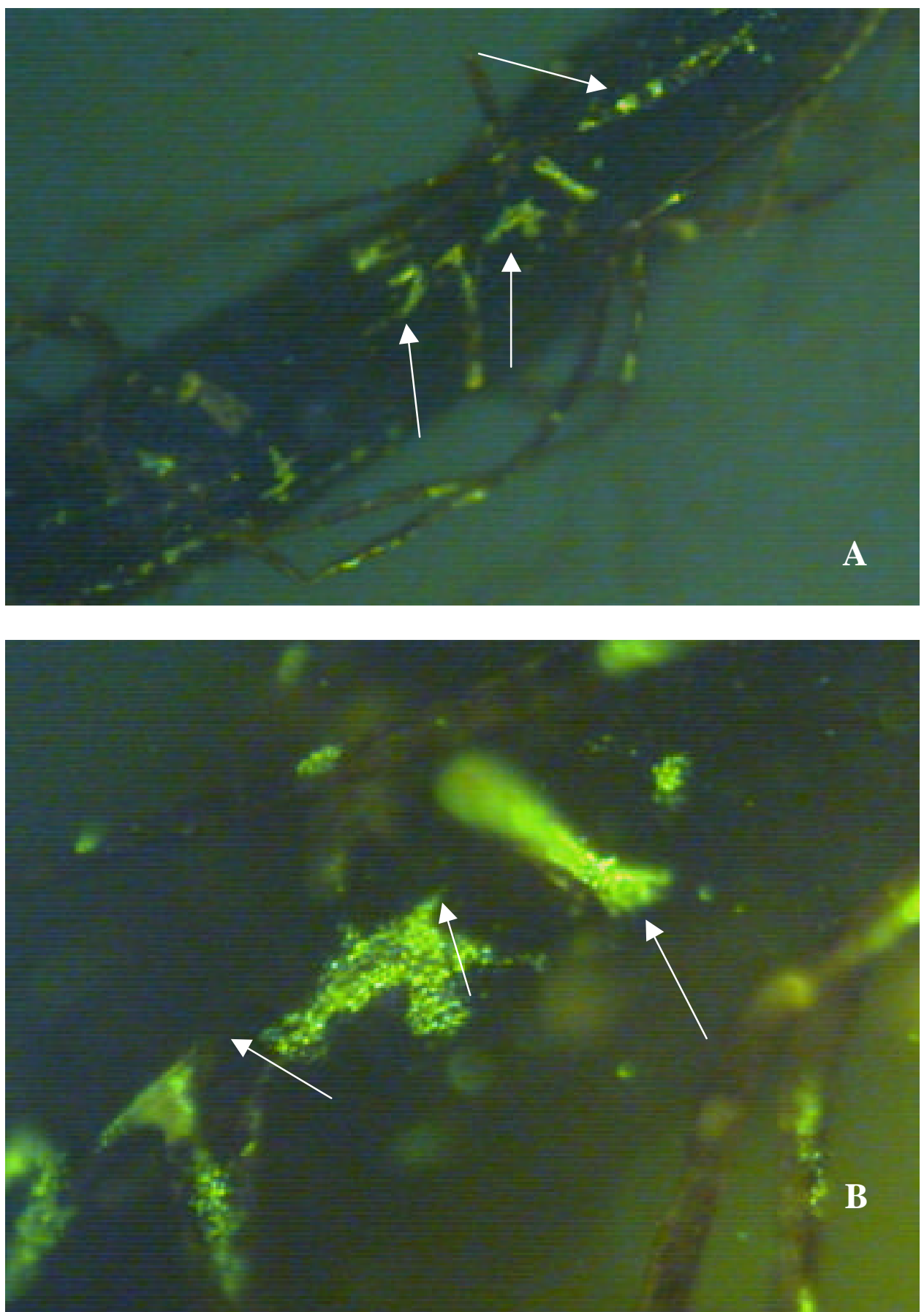

Figure 3. Immunofluorescence (arrows) on roots of fescue at 100x (A) and 400x (B) after incubation with MAb 32B11. 


\section{CHAPTER THREE}

\section{EFFECTS OF TWO CHELATED IRON SOURCES ON THE ACCUMULATION OF GLYCOPROTEIN IN MYCORRHIZAL AND NONMYCORRHIZAL SUDANGRASS}




\section{INTRODUCTION}

Fossil evidence clearly indicates the occurrence of an arbuscular mycorrhizal symbiosis over 400 million years ago (Taylor et al., 1995). Contemporary interactions have shown repeatedly that the fungal symbiont benefits plants by absorbing and translocating immobile nutrients to its plant host in exchange for photoassimilated carbon (Smith and Read, 1997). During the Devonian period, the symbiosis was likely more important to plants than it is today because of nutrient limitations and/or nutrients being supplied in a plant unavailable form (Pirozynski and Malloch, 1975). The soil in this environment also had very little structure and any biological input to increase soil stability would be beneficial to land colonization (Schwartzman and Volk, 1989).

Arbuscular mycorrhizal fungi (AMF) physically increase soil stability via an extensive hyphal network that binds soil particles together (Tisdall et al., 1997). Wright et al. (1996) recently discovered "glomalin", a glycoprotein produced on AMF hyphae, that accumulates on colonized roots and surrounding soil particles. The hydrophobic properties of glomalin cause it to act like glue and improve soil aggregation (Wright and Upadhyaya, 1998). The glycoprotein contains tightly bound iron (2-5\%) that may contribute to its reddish-brown color, stability, and aggregation ability (Wright and Anderson, 1999), by binding covalently to organic matter in aggregates (Kemper and Chepil, 1965).

Iron is one of the most abundant elements in the Earth's crust yet one of the least available to plants, forming stable, insoluble compounds with oxides, carbonates, silicates, and sulphides (Knezek and Ellis, 1980). It is important in plant cells for chlorophyll synthesis and as a component of enzymes, cytochromes and many other proteins. Iron has been shown in several studies to be absorbed by AMF hyphae and translocated to plants (Cress et al., 1986; Clark and Zeto, 1996). The enhanced iron uptake by AM plants may be due to improved host plant root development and morphology with improved uptake of phosphorus and other potentially limiting nutrients (Treeby, 1992).

Other evidence suggests that AMF hyphae produce siderophores, which are chelating compounds that bind to iron making it more available. Clark and Zeto (1996) showed that iron uptake was stimulated by compounds directly associated with AM hyphae, and suggested that these compounds may function as siderophores. Cress et al. (1986) also obtained evidence for the production of siderophores by AMF. Finally, Jayachandran et al. (1989) found that plant growth and $\mathrm{P}$ uptake were significantly greater in mycorrhizal plants when an iron chelator was added. Chelation breaks the iron-phosphorus covalent bond and releases $\mathrm{P}$, making it available for uptake by AMF hyphae or roots. Efficient varieties of plants use similar mechanisms by acidifying the immediate vicinity of the roots or by excreting compounds, siderophores and ferredoxins, capable of reducing the iron to a more soluble and available form. Such interactions may also involve $\mathrm{P}$ uptake, as evidenced by plants in soils with the least available forms of phosphate having the greatest growth response (Bolan et al., 1987).

The concentration of iron in the glomalin molecule varies (Wright, unpubl.), which suggests that it may be functioning as an iron chelator. Because of this close interaction, the concentration of iron in soil may greatly affect glomalin accumulation on AMF hyphae, which in 
turn could influence plant health. In this study, I examined the effects of two typical chelated iron sources (FeEDTA and FeEDDHA) at three concentrations on glomalin accumulation in sudangrass pot cultures. Roots, hyphae, and particulate matter were analyzed together and separately to determine where glomalin deposition is the greatest.

\section{MATERIALS AND METHODS}

\section{Experimental Design}

\section{Pot cultures}

Coarse quartzite sand (85\% of sand collected on \#50 mesh or less) was mixed 2:1 (v/v) with fine sand $\left(68 \%\right.$ on $\# 70$ mesh or greater) and autoclaved at $121^{\circ} \mathrm{C}$ for $1.5 \mathrm{hrs}$ with $50 \mathrm{mM}$ sodium citrate, $\mathrm{pH} 9.0$, to remove any residual protein (Wright et al., 1996). After a thorough rinsing, it was sterilized in an autoclave at $121^{\circ} \mathrm{C}$ for $1 \mathrm{hr}$. An $\sim 350 \mathrm{~cm}^{3}$ plastic cup was placed in the center of a 15-cm ID pot with sterile sand mix filled around it. This cup was replaced by a $28 \mathrm{~cm}$ diam circle of nylon mesh with 45-um openings folded to form a seamless 'bag' with the edges above the sand line (Fig. 1A). Bags were filled with $300 \mathrm{~cm}^{3}$ of presterilized sand:soil mixture (2:1 v/v, pH 6.2) with or without fungal inoculum (Fig. 1B). The inoculum consisted of roots, hyphae, spores, and pot culture soil of Gi. gigantea INVAM accession MN414D mixed 1:8 (v/v) with the presterilized sand:soil mixture. Four 45 -um nylon mesh strips $(4 \mathrm{x} 8 \mathrm{~cm})$ were positioned vertically midway to the pot edge in the sand surrounding the mesh bag (Fig. 1C).

Ten sudangrass (Sorghum sudanese (Piper) Staph.) seeds were placed atop the sand:soil mixes within the mesh bag and covered with $1 \mathrm{~cm}$ of the presterilized sand:soil mix. The number of emergent seedlings varied from 6-10 in most pots. All pots were placed in a growth room (Fig. 1D) and watered once a day for one month and twice a day for another three months with $50 \mathrm{ml}$ of half-strength Hoagland's solution (Millner and Kitt, 1994) without iron or with $20 \mathrm{uM}$, $40 \mathrm{uM}, 60 \mathrm{uM}$ FeEDTA or FeEDDHA (see Appendix B). There were seven treatments total and four replicates per treatment. Throughout the experiment, ambient temperature ranged from 21$28^{\circ} \mathrm{C}$, with a 14-hr photoperiod and light from high-intensity fluorescent light at a photon flux density of 245 umol m $\mathrm{m}^{-2}$ at pot level.

\section{Harvest and foliar tissue analyses}

Mesh strips were removed at monthly intervals beginning at two months. Glomalin was extracted with $20 \mathrm{mM}$ sodium citrate solution, $\mathrm{pH} 7.0$, in the autoclave for $1 \mathrm{hr}$.

At four months, sudangrass shoots were excised and weighed. To measure chlorophyll a and $b$ content, a weighed subsample of leaf tissue was cut into fine pieces and incubated in the dark for $24 \mathrm{hrs}$ in $10 \mathrm{ml}$ of methanol. Samples were vortexed and absorbance was measured using a spectrophotometer at 665,652 , and $750 \mathrm{~nm}$. Concentrations of chl a and chl b were calculated using equations from Porra et al.(1989).

To measure iron and phosphorus content, the remaining shoot tissue was oven-dried at $65^{\circ} \mathrm{C}$, re-weighed, and ground into a fine powder. A $0.25 \mathrm{~g}$ sample of ground tissue was 
transferred to a teflon tube with $3.0 \mathrm{ml}$ of concentrated $\mathrm{HNO}_{3}$ and $0.5 \mathrm{ml}$ of $\mathrm{H}_{2} \mathrm{O}_{2}$ and incubated at room temperature for $15 \mathrm{~min}$. Tube contents were digested using heat and pressure in a microwave (Appendix E). After completion of the microwave cycle, the material was poured through a Whatman \#42 filter and diluted to $25 \mathrm{ml}$ with reagent-grade water. Iron and phosphorus concentrations were measured by inductively-coupled plasma (ICP).

\section{Glycoprotein extraction from various pot media fractions}

At harvest, glycoprotein was extracted from the remaining mesh strips and mesh bags

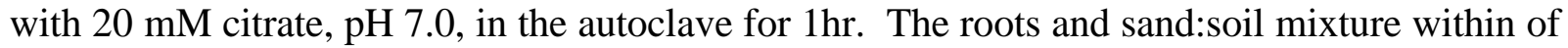
the mesh 'bag' was stored separately from the sand outside of the bag. All the material was manually broken apart and mixed prior to removing random, homogeneous subsamples. The subsamples were utilized as follows: (Sample 1) for percentage colonization determination (only for material within the mesh bag); (Sample 2) dry weight determination; (Sample 3) spore enumeration; (Sample 4) protein extraction; and (Sample 5) further partitioning into particulate matter, roots, and hyphae.

Sample 1. This analysis was only done on material within the mesh bag, since roots did not penetrate the bag and were not found outside of it. Roots were gently removed from the sand:soil mix, and a $\sim 0.2 \mathrm{~g}$ random subsample of rinsed roots was transferred to a tissue cassette which was emersed in boiling $10 \% \mathrm{KOH}(\mathrm{w} / \mathrm{v})$ for $5 \mathrm{~min}$. Cassettes were rinsed, submerged at room temperature in $2 \% \mathrm{HCl}(\mathrm{v} / \mathrm{v})$ for $5 \mathrm{~min}$, and then stained with $0.05 \%$ Direct Blue (w/v) stain in glycerol, lactic acid, and water solution (1:1:1) for 5 min (Phillips and Hayman, 1970). Percentage colonization was determined under a stereoscope via the gridline intersect method (Giovenetti and Mosse, 1980).

Sample 2. A random sample of material from both within (sand:soil mix) and outside (sand) of the 'bag' was excised, weighed, oven-dried at $65^{\circ} \mathrm{C}$ and re-weighed to calculate dry weight. The difference between the fresh weight and dry weight was used to calculate the amount of water in each sample. This value could then be used to determine a dry weight for any freshly weighed sample and even of the whole pot. Measured values, such as glomalin concentration, could then be compared with some standardized baseline (i.e., $\mu \mathrm{g}$ of protein per $\mathrm{g}$ dry sand:soil mix). Also, residual root mass from sample 1 was weighed, dried, and re-weighed to determine dry weight of roots for percent colonization and glomalin production in the roots.

Sample 3. A $50 \mathrm{~cm}^{3}$ sample from both within and outside of the mesh bag was excised for spore extraction. The material was submerged in water in a blender and subjected to three 10 -second bursts and passed through stacked sieves with 500 and 38- $\mu$ m openings. Material on the $38-\mu \mathrm{m}$ sieve was rinsed into a centrifuge tube with a $20 / 60 \%$ sucrose gradient and spun at $900 \mathrm{x} g$ for $1 \mathrm{~min}$. Spores were decanted from centrifuge tubes, washed for 1-2 minutes and then transferred to a Petri dish. Spores were enumerated either by direct counts or by counting the number of spores in certain a number of random grids in a gridline-intersect plate to determine the number for the whole plate. 
Sample 4. A protein extraction with $20 \mathrm{mM}$ sodium citrate, $\mathrm{pH} 7.0$, at $121^{\circ} \mathrm{C}$ in the autoclave for $1 \mathrm{hr}$ was performed on a $0.25 \mathrm{~g}$ subsample (non-sieved) from both within and outside of the mesh bag.

Sample 5. A large amount of the residual material from inside the bag was separated on three different sieves and partitioned even further, as outlined below. The sand:soil mix was weighed and rinsed with forced water through a $500-\mu \mathrm{m}, 150-\mu \mathrm{m}$, and $38-\mu \mathrm{m}$ series of stacked sieves. Roots were removed from the particles on the $500-\mu \mathrm{m}$ sieve, resulting in material $>500$ um and roots alone. Material on the $150-\mu \mathrm{m}$ sieve was submerged in water at room temperature to float root fragments, hyphae, and spores away from particulate matter. The same separation method was performed to separate hyphae on the $38-\mu \mathrm{m}$ sieve from the particles. The following materials were all extracted for protein by autoclaving at $121^{\circ} \mathrm{C}$ for $1 \mathrm{hr}$ with $20 \mathrm{mM}$ citrate at $\mathrm{pH}$ 7.0: roots from the $500-\mu \mathrm{m}$ sieve; $>500 \mu \mathrm{m}$ sieved particles minus roots; roots and fungal material from the $150-\mu \mathrm{m}$ sieve; $>150 \mu \mathrm{m}$ sieved particles minus roots and fungal material; hyphae from $38-\mu \mathrm{m}$ sieve; and > $38 \mu \mathrm{m}$ sieved particle minus hyphae.

For a large portion of the material outside the mesh bag, similar partitioning occurred with stacked 500 and $38-\mu \mathrm{m}$ sieves. Pot contents were rinsed with forced water so material was collected on the $500-\mu \mathrm{m}$ and $38-\mu \mathrm{m}$ sieves, separately. Since hyphae float above the sand, the fraction from the $38-\mu \mathrm{m}$ sieve was easily separated by a series of submerging and decanting at room temperature. Because roots did not penetrate the $45-\mu \mathrm{m}$ mesh bag, there were no roots to separate from sand on the $500-\mu \mathrm{m}$ sieve. Protein was extracted from the sand on the 38 and 500$\mu \mathrm{m}$ sieves and fungal hyphae and spores using $20 \mathrm{mM}$ citrate at $\mathrm{pH} 7.0$ for $1 \mathrm{hr}$ at $121^{\circ} \mathrm{C}$.

\section{Glycoprotein concentration}

One or two samples from each of the groups of extracts (i.e. $>500 \mu \mathrm{m}$ sieved material minus roots from within the mesh bag, hyphae from within the bag, ect.) were assayed for total protein using a modified Bradford protein assay (Bradford, 1976; Wright and Uppadhyaya, 1996). Protein concentration was estimated by the color of the extract (compared to an established color chart (Wright, unpublished)) and from results from previous research. The volume of sample containing 1.25-5.0 $\mu \mathrm{g}$ of protein was placed in 3 replicate wells of a 96-well plate, which were then filled to $200 \mu \mathrm{l}$ with phosphate buffered saline (PBS). Concentration was then determined by addition of $50 \mu \mathrm{l}$ of Bio- $\operatorname{Rad}^{\circledR}$ protein dye and comparison to a bovine serum albumin (BSA) standard curve at $1.25-5.0 \mu \mathrm{g}$ per $200 \mu \mathrm{l}$. These values were used to estimate the volume of sample needed for an immunoreactive concentration of 5-40 $\mathrm{ng}$.

Immunoreactive glycoprotein concentration was measured via enzyme-linked immunosorbent assay (ELISA). The samples were placed in three replicate wells of a Dynex ${ }^{\circledR}$ U-bottom 96-well plate, which were filled to a total volume of $50 \mu 1$ with PBS. After the wells were dry, $2 \%$ nonfat milk in PBS coated any unbound areas in the wells during 15 min incubation. After removal of the milk, $50 \mu \mathrm{l}$ of the monoclonal antibody clone 32B11 was incubated for $1 \mathrm{hr}$. Unbound antibody was washed away by three washes with phosphate buffered saline with $0.02 \%$ Tween 20 (PBST), and a second antibody, a biotinylated anti-mouse IgM was incubated in the wells for $1 \mathrm{hr}$. The wells were again washed with PBST and $50 \mu \mathrm{l}$ of the ExtrAvidin peroxidase 
enzyme solution was added for $1 \mathrm{hr}$. Finally, a color developer solution, containing 1.05\% (w/v) citric acid, ABST (2,2'-Azinobis(3-ethylbenzthiazoline-sulfonic acid), and hydrogen peroxide, was incubated for 15 min prior to reading with a plate reader at $405 \mathrm{~nm}$. Sample concentration was determined by comparison with a standard curve (created from freshly produced, 100\% immunoreactive hyphal glomalin) at concentrations from 5-40 ng. All incubations, except for the color development, were conducted on a tilt table.

\section{Root Immunofluorescence}

Random cultures were picked for an immunofluorescence assay (Wright et al.,1996). Roots and associated hyphae were isolated by rinsing through a $250 \mathrm{um}$ sieve. They were then placed in a $2 \%$ nonfat milk solution and incubated for $30 \mathrm{~min}$. After incubation, the monoclonal antibody clone 32B11 was added for $1 \mathrm{hr}$, followed by three 5-min rinses with PBST. Next, an FITC tagged goat anti-mouse IgM antibody was incubated for $1 \mathrm{hr}$. After this solution was poured off, the roots were again rinsed three times in PBST and once with PBS. Roots were mounted in VectaShield ${ }^{\circledR}$ mounting media (Vector Laboratories, Inc.), and immunofluorescence was detected under a microscope with a band pass combination BP450-BP490 exciter filter, a diachroic chromatic beam splitter FT-510 filter, and a longwave pass LP-520 barrier filter.

\section{Statistical Analysis}

All statistical analyses were performed using $\mathrm{SAS}^{\circledR}$ 6.12 or 7.0. Analysis of Variance (ANOVA) was used on data that had equal variance at the 0.05 level according to Levene's test. Data that did not have equal variances was analyzed via maximum likelihood using a mixed linear model, where data were grouped by variances with 4-fold differences and the Schwarz Bayesian Criterion was used to establish the variable for repeated measures.

\section{RESULTS}

Shoot biomass of 4-month-old sudangrass plants differed dramatically between mycorrhizal and nonmycorrhizal plants (Fig. 2; Tables 1,6). Source of chelated iron (FeEDDHA and FeEDTA) affected shoot production only in mycorrhizal plants, with FeEDDHA appearing to enhance growth slightly more than FeEDTA (Tables 1, 6). Shoot biomass was lowest in pots amended with $40 \mu \mathrm{M}$ FeEDTA, which has values significantly different from pots amended with 40 and $60 \mu \mathrm{M}$ FeEDTA (Table 1). Percentage $\mathrm{P}$ was significantly higher in mycorrhizal than nonmycorrhizal sudangrass (Table 6), while nonmycorrhizal shoots were significantly higher in \% Fe and chl a and b concentrations (Tables $1,6)$.

No fungal colonization and no sporulation was evident in the nonmycorrhizal pots. Colonization of mycorrhizal sudangrass was not affected significantly by iron source orconcentration, except that it was lowest in pots amended with $40 \mu \mathrm{M}$ FeEDTA (Table 2). Spore density was not affected by either iron source or iron concentration (Table 2).

An immunoreactive nonmycorrhizal glycoprotein (described in Chapter 2) was detected in the sand:soil mix within mesh bags, on roots, and nonaggregating hyphae in the sand 
surrounding the mesh bags (Table 3). This glycoprotein was patchily distributed on nonmycorrhizal roots, based on immunofluorescent assays of sudangrass roots (Fig. 3). Glycoprotein concentrations were highest overall in the root and associated fungal material from within the mesh bag and collected on the 150- $\mu$ m sieve (Table 3). Concentrations also were higher on hyphae collected on the $38-\mu \mathrm{m}$ sieve in pots amended with $40 \mu \mathrm{M}$ FeEDTA and 20 $\mu \mathrm{M}$ FeEDDHA.

Iron source alone did not appear to have any consistent effect on nonmycorrhizal glycoprotein concentrations in any organic or inorganic fractions collected. Effects of iron on the inorganic fractions from within and outside the mesh bags varied with iron source and concentration, but not enough to establish any patterns to suggest any major effects either by iron source or the concentrations of each source (Tables 3, 4). Comparing iron treatment effects on glycoprotein concentrations in sand:soil fractions within the mesh bag and sand fractions surrounding the mesh bags (Table 5) also suggests few significant effects.

Concentrations of the nonmycorrhizal glycoprotein and glomalin (mycorrhizal plants) did not differ significantly for inorganic fractions (soil:sand mix or sand particules) on the 500- $\mu \mathrm{m}$ sieve and $150-\mu \mathrm{m}$ sieve (Tables 4,6 ) or for fungal hyphae collected on the $38-\mu \mathrm{m}$ sieve (Tables $3,6)$. Nonmycorrhizal glycoprotein concentrations were significantly higher than glomalin in the inorganic fraction collected on the $38-\mu \mathrm{m}$ sieve (Tables 4,6$)$ and the root and associated fungal material in the sand:soil mix within mesh bags collected on the 150- $\mu$ m sieve (Tables 3 , $6)$.

Although some residual glomalin was contributed by the sand:soil mix $[<124.07 \mu \mathrm{g} / \mathrm{g}$, as determined from extractions of the sand:soil mix added during pot setup (Fig. 1)], most of the fractions from within the bag contained more immunoreactive protein than this amount. Glomalin concentration on mesh strips and mesh bags was below assay detection limits. In the non-sieved sample within the mesh bag, glomalin concentration was almost twice that of the nonmycorrhizal glycoprotein over all iron treatments in the contents of the mesh bags (Tables 5,6). However, the highest concentration of glomalin was measured from the root fraction within mesh bags, and this was at least 10-fold higher than glycoprotein from nonmycorrhizal roots (Fig. 3, 4; Tables 3, 6). Glomalin concentrations also were higher over all iron treatments in the fractions on the $500-\mu \mathrm{m}$ sieve and $38-\mu \mathrm{m}$ sieve minus hyphae from the sand outside mesh bags (Tables 4, 6).

Iron source did not appear to significantly affect amount of glomalin associated with roots inside the mesh bags, with the exception of $60 \mu \mathrm{M}$ FeEDDHA, which stimulated at least $30 \%$ greater glomalin accumulation (Table 3). Iron source or concentration did not significantly impact on glycoprotein accumulation on fungal hyphae within or outside mesh bags. As with the nonmycorrhizal glycoprotein, glomalin concentrations in the inorganic fractions from within and outside the mesh bags varied within iron treatment, but not in patterns that suggested any major effect by either iron source or concentration (Table 4).

The amount of glycoprotein in the non-sieved samples, either of mycorrhizal or nonmycorrhizal origin, was 50 to 100-fold higher in the sand:soil mixture within mesh bags than in the surrounding sand (Tables 5, 6). These amounts were significantly higher in the 
mycorrhizal than in the nonmycorrhizal pots, even after subtracting a background glomalin concentration from the sand:soil fraction within the bag (Tables 5, 6). Finally, glomalin concentrations for the non-sieved samples were highest within mesh bags in pots amended with $60-\mu \mathrm{M}$ FeEDTA and outside mesh bags in pots amended with $40-\mu \mathrm{M}$ FeEDDHA and unamended (no iron) (Table 5).

\section{DISCUSSION}

The two types of chelated iron chosen for this experiment, FeEDDHA and FeEDTA, are strong and weak chelators, respectively. The latter has been most widely used in studies of glomalin production in mycorrhizal plants (Wright et al., 1996; Wright, unpubl.). The former was used in a preliminary experiment, where glomalin concentrations were negligible. In the current study, neither iron source greatly affected the amount of glomalin produced. For example, concentrations of glomalin for a non-sieved sample from within the mesh bag were higher in the FeEDTA-amended pots (means of 0.9-1.2 mg/g) than the FeEDDHA-amended pots (means of $0.5-0.9 \mathrm{mg} / \mathrm{g}$ ), and unamended pots $(0.9 \mathrm{mg} / \mathrm{g})$, but this was neither significant nor consistent for the other fractions.

Since the nonmycorrhizal glycoprotein concentrations in the non-sieved sample; the 38$\mu \mathrm{m}$ sieve fraction minus hyphae; and the roots and fungal material fraction from the $150-\mu \mathrm{m}$ sieve were greater than the background glomalin concentration $(124.07 \mu \mathrm{g} / \mathrm{g})$, the additional protein amounts are probably due to the same nonmycorrhizal glycoprotein found in previous experiments (Chapter 2). After subtraction of the sand:soil background glomalin concentration, glycoprotein concentration of the nonmycorrhizal sudangrass non-sieved sample from within the mesh bag (mean values of 278.1-373.6 $\mu \mathrm{g} / \mathrm{g}$ ) was similar to that in sand cultures of nonmycorrhizal sorghum and tall fescue from a previous experiment (mean values of 49.3-262.9 $\mu \mathrm{g} / \mathrm{g}$ ) (Chapter 2). This illustrates that despite the improvements made to relieve nutrient stress (i.e., (1) non-acid washed sand; (2) a sand:soil mix in part of the pot; and (3) watering more frequently) a nonmycorrhizal glycoprotein is still produced.

Nonmycorrhizal glycoprotein was almost 100-fold higher within the bag than outside of the bag. This was not unexpected, since this nonmycorrhizal glycoprotein is hypothesized to be produced by the plant host and host roots were confined within the mesh bag. The amount of nonmycorrhizal glycoprotein on roots and other fungal material on the $150-\mu \mathrm{m}$ sieve exceeded that of similar fractions in mycorrhizal pots. Also, the glycoprotein concentration in extract from hyphae collected outside the mesh bags did not differ significantly between glomalin and nonmycorrhizal glycoprotein. If the nonmycorrhizal gylcoprotein is produced by the host (as hypothesized in Chapter 2), it is being transferred onto the hyphae outside of the mesh bag at the same rate as glomalin is being created on the hyphae of mycorrhizal plants. None of the results provide any clues as to what variables might be involved in this phenomenon. However, this glycoprotein may have a fungal origin, instead, or there may be two glycoproteins (one fungal and one plant derived), both with similar structures and functions, such as being an iron chelator.

In experiments conducted with different growing conditions, such as higher light intensities, constant humidity of $70 \%$, and ambient temperatures, amounts of glomalin in sand can reach $\mathrm{mg} / \mathrm{g}$ quantities ( up to $63 \mathrm{mg}$ of glomalin per g hyphae) (Wright et al., 1996; Wright, 
unpubl.). All of the glomalin concentrations for the mycorrhizal cultures were 10 to 100 -fold lower than the expected mg quantities, except for the extract from the roots from $500 \mu \mathrm{m}$ sieves. Glomalin production was greatest in the root fraction, root and fungal material from the $150 \mu \mathrm{m}$ sieve, hyphae from the $38 \mu \mathrm{m}$ sieve, and particles from the $38 \mu \mathrm{m}$ sieve. Since these samples are from within the mesh bag, the background sand:soil concentration may be influencing these values. However, before subtracting this background from each of these values, data must be normalized over all these fractions, because they all came from one original sand:soil sample. The influence of this background values on these individual samples is very small.

Glomalin and nonmycorrhizal glycoprotein accumulation were both lower in the material outside than within the mesh bag. This indicates lower fungal biomass outside of the bag for the mycorrhizal treatment. Fresh hyphal weight within and outside of the mesh bag was average $5.99 \mathrm{~g}$ and $3.71 \mathrm{~g}$, respectively, for mycorrhizal cultures. For the nonmycorrhizal cultures, hyphae outside the mesh bag weighed $0.87 \mathrm{~g}$. Spore density was also reduced from an average of 14 to 4 from within to outside of the bag, respectively.

Growth room conditions were similar to those in the preliminary experiment (Appendix A) and Chapter 2, except sand used in this study was not acid-washed to remove iron, a sand:soil mix was used in the mesh bag, and pots were watered twice daily with nutrient solutions. These conditions appeared to relieve some of the nutrient stress, since these plants had a greater shoot biomass and did not exhibit chlorosis or phosphate stress, like those in preliminary experiment (Appendix A). Foliar tissue iron concentration of the plants in this experiment were 0.005$0.016 \%$, which is similar to the ideal concentration of $0.006-0.008 \%$, while phosphorus concentration was low, 0.038-0.046\% compared 0.1-0.8\% (Raven et al., 1992). The lower phosphorus concentration was probably due to the low phosphorus nutrient solution, but the plants did not exhibit signs of phosphorus deficiency.

Lighting conditions continued to be a constraint on photosynthetic activity and plant physiology. Carbon drain in the production of glomalin is considerable, since carbon accounts for approximately $30 \%$ the weight of this $90 \mathrm{KD}$ glycoprotein (Wright and Anderson, 1999; Wright et al., 1998). In this study, mycorrhizal activity [i.e., hyphal biomass (3.7-6.0 g), spore density (5.0-14.0 spores/g), and percent mycorrhizal colonization (51-78\%)] was normal relative to published values (Abbott and Robson, 1984; Grahman et al.,1991; Pearson and Schweiger, 1993; Sylvia, 1988; Wright et al.,1996; Vilarino et al.,1997). However, glomalin accumulation remained low (at least 10-fold less) compared to published values of $63 \mu \mathrm{g} / \mathrm{g}$ of hyphae and 4.4$14.4 \mathrm{mg} / \mathrm{g}$ of field soil (Wright et al., 1996). Therefore, the necessity for glomalin production (i.e., iron deficiency or iron in an unavailable form) may not exist in this experiment. Also, low photosynthetic activity would limit carbon availability. Sugar exudates are the highest with a total PAR (photosyntheticly active radiation) of $292 \mu \mathrm{mol} \mathrm{m} \mathrm{s}^{-2} \mathrm{~s}^{-1}$ (with $6 \mathrm{hr}$ light from mercury vapor lamps after $10 \mathrm{hr}$ of natural daylight) to $501 \mu \mathrm{mol} \mathrm{m} \mathrm{m}^{-1}$ (with $12 \mathrm{hr}$ of metal halide lamp light after $10 \mathrm{hr}$ of natural daylight) (Fergunson and Menge, 1982). The first carbon sink would be hyphal production followed by production of glomalin on hyphae.

Percent foliar iron and chlorophyll concentrations were both significantly higher in the nonmycorrhizal cultures, while shoot weight was lower. If the nonmycorrhizal glycoprotein produced in these cultures is an iron chelator, it may be enhancing iron uptake. This iron is then 
used in chlorophyll formation and photosynthesis. Since iron and chlorophyll are present in greater concentrations in these plants, the carbon fixed appears to be partitioned to other sinks, such as more glycoprotein production, than to shoot biomass production. Such allocation patterns are typical of phytosiderophores that are less efficient than microbial siderophores and result in a higher carbon cost (Crowley et al., 1992). In mycorrhizal plants, iron concentrations were within the expected range (Marschner, 1995), suggesting that iron is being absorbed in sufficient amounts. The higher shoot biomass in these plants indicates that the iron is being absorbed efficiently and residual iron and/or carbon can be allocated to fungal and glomalin production.

The nonmycorrhizal glycoprotein, found in these cultures and in the background glomalin concentration from the sand:soil mix make it difficult to assess the exact amount of glomalin accumulated in this study. Only extracts from the root fraction (which was significantly greater for mycorrhizal versus nonmycorrhizal and was present in mg quantities) and the immunofluorescent material on mycorrhizal hyphae (Fig. 3) establish conclusively that glomalin was actually produced in these cultures. Despite mimicking many of the conditions used in other studies on glomalin production in mycorrhizal plants (Wright et al.,1996; Wright, unpubl.), glomalin production was 10 to 100 times less than expected. The only differences between the one conducted in this thesis and these other studies are: (1) use of sand:soil mix instead of a sand:crushed coal mix; (2) watering twice a day by hand as opposed to watering four times a day with an automatic watering system; and (3) a $14 \mathrm{~h}$ photoperiod with high intensity fluorescent lights $\left(245 \mu \mathrm{mol} \mathrm{m}^{-1} \mathrm{~s}^{-1}\right)$ compared to an $18 \mathrm{~h}$ photoperiod with sodium vapor lamps (200-700 $\mu \mathrm{mol} \mathrm{m} \mathrm{m}^{-1}$ ). The lower light intensity of these fluorescent lights, expecially at the red end of the spectrum, reduced photosynthetic activity and the amount of carbon available for glomalin production. Also, the use of only chelated iron, which is available to both the plant and fungus, would negate the necessity of an iron binding substance, such as glomalin. However, the crushed coal used in the other studies may contain unavailable iron or some other compound that stimulated glomalin production. Future research comparing these three variables may resolve how to trigger glomalin production.

\section{LITERATURE CITED}

Abbott, L.K. and A.D. Robson. 1984. Colonization of the root system of subterranean clover by three species of vesicular-arbuscular mycorrhizal fungi. New Phytologist 96:275-281.

Bolan, N.S. 1991. A critical review on the role of mycorrhizal fungi in the uptake of phosphorus by plants. Plant and Soil 134:189-207.

Bolan, N.S., A.D. Robson, and N.J. Barrow. 1987. Effects of vesicular-arbuscular mycorrhiza on the availability of iron phosphates to plants. Plant and Soil 99:401-410.

Bradford, M.M. 1976. A rapid and sensitive method for the quanitation of microgram quantities of protein utilizing the principle of protein-dye binding. Analytical Biochemistry 72:248254.

Clark, R.B. and S.K. Zeto. 1996. Iron acquisition by mycorrhizal maize grown on alkaline soil. Journal of Plant Nutrition 19:247-264.

Cress, W.A., G.V. Johnson, and L.L. Barton. 1986. The role of endomycorrhizal fungi in iron uptake by Hilaria Jamesii. Journal of Plant Nutrition 9:547-556. 
Crowley, D.E., V. Romheld, H. Marschner, and P.J. Szaniszlo. 1992. Root-microbial effects on plant iron uptake form siderophores and phytosiderophores. Plant and Soil 142:1-7.

Fay, P., D.T. Mitchell, and B.A. Osborne. 1996. Photosynthesis and nutrient-use efficiency of barley in response to low arbuscular mycorrhizal colonization and addition of phosphorus. New Phytologist 132:425-433.

Ferguson, J.J. and J.A. Menge. 1982. The influence of light intensity and artifically extended photoperiod upon infection and sporulation of Glomus fasciculatus on sudan grass and on root exudation of sudan grass. New Phytologist 92:183-191.

Giovannetti, M., and B. Mosse. 1980. An evaluation of techniques for measuring vesicular arbuscular mycorrhizal infection in roots. New Phytologist 84:489-500.

Graham, J.H., D.M. Eissenstat, and D.L. Drouillard. 1991. On the relationship between a plant's mycorrhizal dependency and rate of vesicular-arbuscular mycorrhizal colonization. Functional Ecology 5:773-779.

Jayachandran, K., A.P. Schwab, and B.A.D. Hetrick. 1989. Mycorrhizal mediation of phosphorus availability: Synthetic iron chelate effects on phosphorus solubilization. Soil Science Society of America Journal 53:1701-1706.

Kemper. W.D. and W.S. Chepil. 1965. Size distribution of aggregates. In: Methods of soil analysis, Part I. Ed: C.A. Black. Agronomy No. 9. American Society of Agronomy 499509.

Knezek, B.D., and B.G. Ellis. 1980. Essentail micronutrients IV: Copper, Iron, Manganese, and Zinc. In: Applied Soil Trace Elements. Ed.: B.E. Davis. John Wiley \& Sons Ltd.

Lucena, J.J., A. Garate, A.M. Ramon, and M. Manzanares. 1990. Iron nutrition of a hydroponic strawberry culture (Fragaria vesca L.) supplied with different Fe chelates. Plant and Soil. 123:9-15.

Marschner, H. 1995. Mineral Nutrition of Higher Plants. Academic Press. Harcourt Brace \& Company. New York.

Millner, P.D., and D.G. Kitt. 1992. The Beltsville method for soilless production of vesiculararbuscular mycorrhizal fungi. Mycorrhiza 2:9-15.

Pearson, J.N., and P. Schweiger. 1993. Scutellospora calospora (Nicol. \& Gerd.) Walker \& Sanders associated with subterranean clover: dynamics of colonization, sporulation and soluble carbohydrates. New Phytologist 124:215-219.

Phillips, J.M. and D.S. Hayman. 1970. Improved procedures for clearing roots and staining parasitic and vesicular-arbuscular fungi for rapid assessment of infection. Transactions of the British Mycological Society 55:158-161.

Pirozynski, K.A. and D.W. Malloch. 1975. The origin of land plants: A matter of mycotrophism. BioSystems 6:153-164.

Porra, R.L., W.A. Thompson, and P.E. Kreidemann. 1989. Determination of accurate extinction coefficients and simultaneous equations for assaying chlorophylls $a$ and $b$ extracted with four different solvents: verification of the concentration of chlorophyll standards by atomic adsorption spectroscopy. Biochimica et Biophysica Acta 975:384-394.

Raven, P.H., R.F. Evert, S.E. Eichhorn. 1992. Biology of Plants-5 ${ }^{\text {th }}$ Edition. Worth Publishers. New York, New York.

Schwartzman, D.W. and T. Volk. 1989. Biotic enhancement of weathering and the habitability of Earth. Nature 340:457-460. 
Smith, S. and V. Gianinazzi-Pearson. 1988. Physiological interactions between symbionts in vesicular-arbuscular mycorrhizal plants. Annual Review of Plant Physiology and Plant Molecular Biology 39:221-244.

Smith, S.E. and D.J. Read. 1997. Mycorrhizal symbiosis, $2^{\text {nd }}$ Edition. Academic Press: Sand Diego.

Sylvia, D.M. 1988. Activity of external hyphae of vesicular-arbuscular mycorrhizal fungi. Soil Biology and Biochemistry 20:39-43.

Taiz, L. and E. Zeiger. 1991. Plant Physiology. The Benjamin/Cummings Publishing Company, Inc. p. 22.

Taylor, T.N., W. Remy, H. Haas, and H. Kerp. 1995. Fossil arbuscular mycorrhizae from the Early Devonian. Mycologia 87:560-573.

Tisdall, J.M., S.E. Smith, and P. Rengasamy. 1997. Aggregation of soil by fungal hyphae. Australian Journal of Soil Research 35:55-60.

Treeby, M.T. 1992. The role of mycorrhizal fungi and non-mycorrhizal micro-organisms in iron nutrition of citrus. Soil Biology and Biochemistry 24:857-864.

Vilarino, A., B. Frey, H. Shuepp. 1997. MES [2-(N-morholine)-ehtane sulphonic acid] buffer promotes the growth of external hyphae of the arbuscular mycorrhizal fungus Glomus intraradices in an alkaline sand. Bioliogy and Fertility of Soils 25:79-81.

Wright, S.F. and R.L. Anderson. 1999. Aggregate stability and glomalin in alternative crop rotations for the Central Great Plains. Biology and Fertility of Soils (In Press).

Wright, S.F., M. Franke-Snyder, J.B. Morton, and A. Upadhyaya. 1996. Time-course study and partial characterization of a protein on arbuscular mycorrhizal hyphae during active colonization of roots. Plant and Soil 181:193-203.

Wright, S.F., J.B. Morton, and J.E. Sworobuk. 1987. Identification of a vesicular-arbuscular mycorrhizal fungus by using monoclonal antibodies in an enzyme-linked immunosorbent assay. Applied Environmental Microbiology 53:2222-2225.

Wright, S.F. and A. Upadhyaya. 1996. Extraction of an abundant and unusual protein from soil and comparison with hyphal protein of arbuscular mycorrhizal fungi. Soil Science 161:575-586.

Wright, S.F., and A. Upadhyaya. 1998. A survey of soils for aggregate stability and glomalin, a glycoprotein produced by hyphae of arbuscular mycorrhizal fungi. Plant and Soil 198:97107.

Wright, S.F., A. Upadhyaya, and J.S. Buyer. 1998. Comparison of N-linked oligosaccharides of glomalin from arbuscular mycorrhizal fungi and soils by capillary electorphoresis. Soil Biology and Biochemistry 30:1853-1857.

Wright, S.F. and Upadhyaya, A. 1999. Quantification of arbuscular mycorrhizal fungi activity by the glomalin concentration on hyphal traps. Mycorrhiza 8:283-28. 
Table 1. Foliar tissue analysis (mean $\pm \mathrm{SE}$ )* of mycorrhizal and nonmycorrhizal sudangrass treated with different concentrations of FeEDTA or FeEDDHA.

\begin{tabular}{|c|c|c|c|c|c|c|c|}
\hline $\begin{array}{l}\text { Myc/ } \\
\text { NM }\end{array}$ & Iron sourc & & $\begin{array}{l}\text { shoot dry } \\
\text { wght (g) }\end{array}$ & $\% \mathrm{P}$ & $\% \mathrm{Fe}$ & $\begin{array}{l}\text { Chl a } \\
(\mathrm{mg} / \mathrm{g})\end{array}$ & Chl b (mg/g) \\
\hline \multirow{7}{*}{ Мyc } & \multicolumn{2}{|l|}{ No iron } & $5.1 \pm 0.41^{\mathrm{ab}}$ & $0.05 \pm 0.002^{\mathrm{abcd}}$ & $0.007 \pm 0.001^{\mathrm{b}}$ & $1.11 \pm 0.14^{\mathrm{b}}$ & $0.25 \pm 0.03^{\mathrm{de}}$ \\
\hline & \multirow{3}{*}{$\begin{array}{l}\text { FeEDTA } \\
(\mu \mathrm{M})\end{array}$} & 20 & $5.1 \pm 0.16^{\mathrm{ab}}$ & $0.04 \pm 0.001^{\mathrm{abcdef}}$ & $0.005 \pm 0.000^{\mathrm{b}}$ & $0.90 \pm 0.17^{\mathrm{b}}$ & $0.22 \pm 0.05^{\mathrm{bcd}}$ \\
\hline & & 40 & $4.8 \pm 0.12^{\mathrm{a}}$ & $0.04 \pm 0.002^{\text {abcdef }}$ & $0.008 \pm 0.000^{\mathrm{b}}$ & $0.99 \pm 0.04^{\mathrm{b}}$ & $0.22 \pm 0.01^{\text {bcd }}$ \\
\hline & & 60 & $5.0 \pm 0.22^{\mathrm{ab}}$ & $0.04 \pm 0.002^{\text {abcdefg }}$ & $0.009 \pm 0.001^{\mathrm{b}}$ & $1.04 \pm 0.08^{\mathrm{b}}$ & $0.23 \pm 0.01^{\mathrm{bc}}$ \\
\hline & \multirow{3}{*}{$\begin{array}{l}\text { FeEDDHA } \\
\qquad(\mu \mathrm{M})\end{array}$} & 20 & $5.2 \pm 0.39^{\mathrm{ab}}$ & $0.04 \pm 0.001^{\mathrm{abcdef}}$ & $0.007 \pm 0.000^{\mathrm{b}}$ & $1.19 \pm 0.02^{\mathrm{b}}$ & $0.28 \pm 0.01^{\mathrm{de}}$ \\
\hline & & 40 & $5.6 \pm 0.30^{\mathrm{b}}$ & $0.05 \pm 0.000^{\text {abcde }}$ & $0.008 \pm 0.001^{\mathrm{b}}$ & $1.08 \pm 0.08^{\mathrm{b}}$ & $0.24 \pm 0.01^{\mathrm{bcd}}$ \\
\hline & & 60 & $5.6 \pm 0.19^{\mathrm{b}}$ & $0.04 \pm 0.002^{\text {abcdef }}$ & $0.009 \pm 0.000^{\mathrm{b}}$ & $1.06 \pm 0.20^{\mathrm{b}}$ & $0.25 \pm 0.05^{\mathrm{bcd}}$ \\
\hline \multirow{7}{*}{ NM } & \multicolumn{2}{|l|}{ No iron } & $2.9 \pm 0.15^{\mathrm{c}}$ & $0.04 \pm 0.002^{\text {defg }}$ & $0.008 \pm 0.001^{\mathrm{b}}$ & $1.21 \pm 0.10^{\mathrm{b}}$ & $0.27 \pm 0.01^{\text {abcde }}$ \\
\hline & \multirow{3}{*}{$\begin{array}{l}\text { FeEDTA } \\
(\mu \mathrm{M})\end{array}$} & 20 & $3.5 \pm 0.23^{c}$ & $0.04 \pm 0.003^{\text {bcdefg }}$ & $0.010 \pm 0.001^{\mathrm{a}}$ & $1.24 \pm 0.32^{\mathrm{ab}}$ & $0.27 \pm 0.07^{\text {abcde }}$ \\
\hline & & 40 & $3.0 \pm 0.18^{\mathrm{c}}$ & $0.04 \pm 0.002^{\text {abcdefg }}$ & $0.013 \pm 0.002^{\mathrm{a}}$ & $1.74 \pm 0.32^{\mathrm{a}}$ & $0.43 \pm 0.10^{\mathrm{ab}}$ \\
\hline & & 60 & $3.1 \pm 0.27^{\mathrm{c}}$ & $0.04 \pm 0.002^{\text {bcdefg }}$ & $0.014 \pm 0.003^{\mathrm{a}}$ & $1.27 \pm 0.25^{\mathrm{ab}}$ & $0.29 \pm 0.05^{\mathrm{ab}}$ \\
\hline & \multirow{3}{*}{$\begin{array}{l}\text { FeEDDHA } \\
\qquad(\mu \mathrm{M})\end{array}$} & 20 & $3.2 \pm 0.14^{\mathrm{c}}$ & $0.04 \pm 0.001^{\text {abcdefg }}$ & $0.016 \pm 0.006^{\mathrm{a}}$ & $1.15 \pm 0.09^{b}$ & $0.27 \pm 0.02^{\text {abcde }}$ \\
\hline & & 40 & $3.1 \pm 0.20^{c}$ & $0.04 \pm 0.001^{\text {cdef }}$ & $0.013 \pm 0.002^{\mathrm{a}}$ & $1.15 \pm 0.10^{\mathrm{b}}$ & $0.25 \pm 0.02^{\mathrm{ab}}$ \\
\hline & & 60 & $3.1 \pm 0.42^{\mathrm{c}}$ & $0.04 \pm 0.002^{\text {cdefg }}$ & $0.013 \pm 0.001^{\mathrm{a}}$ & $1.22 \pm 0.10^{\mathrm{ab}}$ & $0.28 \pm 0.03^{\text {abcd }}$ \\
\hline
\end{tabular}

*Values followed by the same letter in each column are not significantly different at 0.05 . 
Table 2. Percentage mycorrhizal colonization and fungal sporulation within (sand:soil mix) and outside (sand) of the mesh bag (mean \pm SE)* of mycorrhizal sudangrass amended with different concentrations of FeEDTA or FeEDDHA.

\begin{tabular}{|cccc|}
\hline Iron Source & $\begin{array}{c}\text { Percentage } \\
\text { colonization }\end{array}$ & $\begin{array}{c}\text { Spore density per g } \\
\text { of sand:soil mix }\end{array}$ & $\begin{array}{c}\text { Spore density per g } \\
\text { of sand }\end{array}$ \\
\hline No iron & $76 \pm 7^{\mathrm{a}}$ & $17 \pm 1^{\mathrm{a}}$ & $3 \pm 1^{\mathrm{a}}$ \\
\hline $20 \mu \mathrm{M}$ FeEDTA & $71 \pm 4^{\mathrm{a}}$ & $16 \pm 1^{\mathrm{a}}$ & $5 \pm 0^{\mathrm{a}}$ \\
$40 \mu \mathrm{M}$ FeEDTA & $51 \pm 4^{\mathrm{b}}$ & $14 \pm 2^{\mathrm{a}}$ & $5 \pm 1^{\mathrm{a}}$ \\
$60 \mu \mathrm{M}$ FeEDTA & $73 \pm 6^{\mathrm{a}}$ & $12 \pm 3^{\mathrm{a}}$ & $4 \pm 1^{\mathrm{a}}$ \\
\hline $20 \mu \mathrm{M}$ FeEDDHA & $66 \pm 4^{\mathrm{ab}}$ & $12 \pm 2^{\mathrm{a}}$ & $4 \pm 1^{\mathrm{a}}$ \\
$40 \mu \mathrm{M}$ FeEDDHA & $63 \pm 8^{\mathrm{ab}}$ & $12 \pm 5^{\mathrm{a}}$ & $5 \pm 0^{\mathrm{a}}$ \\
$60 \mu \mathrm{M}$ FeEDDHA & $78 \pm 5^{\mathrm{a}}$ & $16 \pm 2^{\mathrm{a}}$ & $5 \pm 1^{\mathrm{a}}$ \\
\hline
\end{tabular}

*Values followed by the same letter in each column are not significantly different at 0.05 . 
Table 3. Glomalin and nonmycorrhizal glycoprotein concentrations (means $\pm \mathrm{SE}$ )* on various sieved fractions containing roots and/or fungal material from within the mesh bag: (i) roots on $500 \mu \mathrm{m}$ sieve ( $\mu \mathrm{g}$ protein per $\mathrm{g}$ of roots); (ii) roots and fungal material on $150 \mu \mathrm{m}$ sieve ( $\mu \mathrm{g}$ protein per $\mathrm{g}$ of roots and fungal material); and (iii) hyphae on $38 \mu \mathrm{m}$ sieve ( $\mu \mathrm{g}$ protein per $\mathrm{g}$ of fresh hyphae); and from hyphae on $38 \mu \mathrm{m}$ sieve outside the mesh bag ( $\mu \mathrm{g}$ protein per $\mathrm{g}$ of fresh hyphae).

\begin{tabular}{|c|c|c|c|c|c|c|}
\hline \multirow[b]{2}{*}{$\begin{array}{c}\text { Myc/ } \\
\text { NM }\end{array}$} & \multirow{2}{*}{\multicolumn{2}{|c|}{ Iron source }} & \multicolumn{3}{|c|}{ Within mesh bag } & \multirow{2}{*}{$\begin{array}{c}\text { Outside mesh } \\
\text { bag }\end{array}$} \\
\hline & & & Roots & $\begin{array}{l}\text { Roots and } \\
\text { assorted fungal } \\
\text { structures }\end{array}$ & Hyphae & \\
\hline \multirow{7}{*}{ Myc } & \multicolumn{2}{|l|}{ No iron } & $1355.6 \pm 609.5^{\mathrm{ab}}$ & $198.9 \pm 19.48^{b}$ & $336.9 \pm 39.59^{\mathrm{a}}$ & $92.6 \pm 29.70^{\mathrm{abc}}$ \\
\hline & \multirow[t]{3}{*}{$\begin{array}{l}\text { FeEDTA } \\
(\mu \mathrm{M})\end{array}$} & 20 & $1718.1 \pm 649.0^{\mathrm{ab}}$ & $208.8 \pm 8.45^{\mathrm{b}}$ & $359.4 \pm 86.36^{\mathrm{a}}$ & $61.2 \pm 14.08^{\mathrm{abc}}$ \\
\hline & & 40 & $1102.6 \pm 407.9^{\mathrm{ab}}$ & $561.4 \pm 214.67^{\mathrm{a}}$ & $362.1 \pm 50.54^{\mathrm{a}}$ & $52.6 \pm 9.27^{\mathrm{abc}}$ \\
\hline & & 60 & $1585.6 \pm 353.5^{\mathrm{ab}}$ & $272.6 \pm 88.35^{\mathrm{b}}$ & $307.5 \pm 51.47^{\mathrm{a}}$ & $72.4 \pm 15.23^{\mathrm{abd}}$ \\
\hline & \multirow[t]{3}{*}{$\begin{array}{c}\text { FeEDDHA } \\
(\mu \mathrm{M})\end{array}$} & 20 & $1853.6 \pm 684.8^{\mathrm{ab}}$ & $174.8 \pm 20.16^{\mathrm{b}}$ & $357.5 \pm 28.58^{\mathrm{a}}$ & $55.6 \pm 10.68^{\mathrm{abc}}$ \\
\hline & & 40 & $838.3 \pm 148.1^{\mathrm{ab}}$ & $207.9 \pm 15.23^{b}$ & $912.9 \pm 395.05^{\mathrm{a}}$ & $46.2 \pm 2.24^{\mathrm{c}}$ \\
\hline & & 60 & $3093.4 \pm 2585.8^{\mathrm{a}}$ & $386.8 \pm 194.38^{\mathrm{ab}}$ & $276.2 \pm 56.18^{a}$ & $63.4 \pm 13.39^{\mathrm{abc}}$ \\
\hline \multirow{7}{*}{ NM } & \multicolumn{2}{|l|}{ No iron } & $19.2 \pm 6.7^{\mathrm{b}}$ & $530.5 \pm 59.60^{a}$ & $\mathrm{Na}$ & $44.1 \pm 7.60^{\mathrm{abc}}$ \\
\hline & \multirow[t]{3}{*}{$\begin{array}{l}\text { FeEDTA } \\
(\mu \mathrm{M})\end{array}$} & 20 & $13.2 \pm 1.3^{\mathrm{b}}$ & $271.4 \pm 50.07^{\mathrm{b}}$ & $\mathrm{Na}$ & $50.0 \pm 5.28^{\mathrm{bc}}$ \\
\hline & & 40 & $18.6 \pm 1.9^{\mathrm{b}}$ & $282.6 \pm 36.97^{b}$ & $\mathrm{Na}$ & $96.7 \pm 35.49^{\mathrm{ab}}$ \\
\hline & & 60 & $19.8 \pm 4.1^{\mathrm{b}}$ & $354.3 \pm 27.65^{\mathrm{ab}}$ & $\mathrm{Na}$ & $46.1 \pm 4.06^{\mathrm{cd}}$ \\
\hline & \multirow[t]{3}{*}{$\begin{array}{c}\text { FeEDDHA } \\
(\mu \mathrm{M})\end{array}$} & 20 & $12.4 \pm 0.8^{b}$ & $342.9 \pm 71.82^{\mathrm{ab}}$ & $\mathrm{Na}$ & $107.0 \pm 27.78^{\mathrm{a}}$ \\
\hline & & 40 & $16.9 \pm 6.6^{\mathrm{b}}$ & $372.1 \pm 54.90^{\mathrm{ab}}$ & $\mathrm{Na}$ & $45.8 \pm 4.38^{c}$ \\
\hline & & 60 & $14.9 \pm 0.8^{\mathrm{b}}$ & $436.8 \pm 99.04^{\mathrm{ab}}$ & $\mathrm{Na}$ & $52.9 \pm 7.68^{\mathrm{bc}}$ \\
\hline
\end{tabular}

*Values followed by the same letter in each column are not significantly different at 0.05 . 
Table 4. Glomalin and nonmycorrhizal glycoprotein concentration $(\mu \mathrm{g} / \mathrm{g})(\mathrm{mean} \pm \mathrm{SE})^{*}$ on sieved sand:soil or sand fractions from mycorrhizal or nonmycorrhizal sudangrass treated with different concentrations of FeEDTA or FeEDDHA.

\begin{tabular}{|c|c|c|c|c|c|c|}
\hline \multirow[b]{2}{*}{ Iron source } & \multirow[b]{2}{*}{$\begin{array}{l}\text { Myc } \\
\text { /NM }\end{array}$} & \multicolumn{3}{|c|}{ Within mesh bag } & \multicolumn{2}{|c|}{ Outside mesh bag } \\
\hline & & $\begin{array}{c}500 \mu \mathrm{m} \text { sieve } \\
\text { fraction } \\
\text { (- roots) }\end{array}$ & $\begin{array}{c}150 \mu \mathrm{m} \text { sieve } \\
\text { fraction } \\
\text { (- roots \& } \\
\text { fungal } \\
\text { material) }\end{array}$ & $\begin{array}{c}38 \mu \mathrm{m} \text { sieve } \\
\text { fraction } \\
\text { (- hyphae) }\end{array}$ & $\begin{array}{l}500 \mu \mathrm{m} \\
\text { sieve } \\
\text { fraction }\end{array}$ & $\begin{array}{l}38 \mu \mathrm{m} \text { sieve } \\
\text { fraction } \\
(- \text { hyphae })\end{array}$ \\
\hline No iron & Myc & $17.1 \pm 1.94^{\text {defghij }}$ & $67.2 \pm 8.85^{\mathrm{a}}$ & $119.0 \pm 27.02^{\text {cde }}$ & $9.42 \pm 3.09^{\mathrm{a}}$ & $6.40 \pm 0.58^{\mathrm{a}}$ \\
\hline $\begin{array}{c}20 \mu \mathrm{M} \\
\text { FeEDTA }\end{array}$ & Myc & $16.0 \pm 2.39^{\text {efghij }}$ & $57.9 \pm 9.16^{\mathrm{ab}}$ & $100.1 \pm 7.0^{\mathrm{e}}$ & $5.63 \pm 0.99^{\mathrm{abc}}$ & $4.82 \pm 0.15^{\mathrm{ab}}$ \\
\hline $\begin{array}{c}40 \mu \mathrm{M} \\
\text { FeEDTA }\end{array}$ & Myc & $12.7 \pm 1.87^{\text {fghij }}$ & $64.7 \pm 7.91^{\mathrm{a}}$ & $123.7 \pm 15.75^{\mathrm{cde}}$ & $4.11 \pm 0.42^{c}$ & $5.21 \pm 0.63^{\mathrm{ab}}$ \\
\hline $\begin{array}{c}60 \mu \mathrm{M} \\
\text { FeEDTA } \\
\end{array}$ & Myc & $16.8 \pm 1.42^{\text {efghij }}$ & $43.9 \pm 1.41^{\mathrm{b}}$ & $96.0 \pm 7.80^{\mathrm{e}}$ & $5.17 \pm 0.99^{\mathrm{bc}}$ & $4.11 \pm 0.41^{\mathrm{b}}$ \\
\hline $\begin{array}{c}20 \mu \mathrm{M} \\
\text { FeEDDHA }\end{array}$ & Myc & $19.9 \pm 2.83^{\text {cdefghij }}$ & $55.4 \pm 7.66^{\mathrm{ab}}$ & $130.8 \pm 12.87^{\text {bcde }}$ & $5.08 \pm 0.89^{b c}$ & $3.86 \pm 0.43^{b}$ \\
\hline $\begin{array}{c}40 \mu \mathrm{M} \\
\text { FeEDDHA }\end{array}$ & Myc & $15.8 \pm 3.49^{\text {efghij }}$ & $81.1 \pm 26.30^{\mathrm{ab}}$ & $207.50 \pm 23.29^{\mathrm{a}}$ & $5.88 \pm 0.88^{\mathrm{abc}}$ & $4.91 \pm 0.55^{\mathrm{ab}}$ \\
\hline $\begin{array}{c}60 \mu \mathrm{M} \\
\text { FeEDDHA }\end{array}$ & Myc & $20.6 \pm 1.56^{\text {bcdefghij }}$ & $40.3 \pm 7.92^{b c}$ & $121.5 \pm 20.36^{\mathrm{de}}$ & $7.97 \pm 1.26^{\mathrm{ab}}$ & $5.09 \pm 0.72^{\mathrm{ab}}$ \\
\hline No iron & NM & $28.0 \pm 3.48^{\text {abcdefg }}$ & $66.2 \pm 8.54^{\mathrm{a}}$ & $124.5 \pm 0.99^{\text {cde }}$ & $0.37 \pm 0.06^{\mathrm{d}}$ & $1.64 \pm 0.22^{\mathrm{c}}$ \\
\hline $\begin{array}{c}20 \mu \mathrm{M} \\
\text { FeEDTA }\end{array}$ & NM & $20.1 \pm 3.46^{\text {bcdefghij }}$ & $71.1 \pm 9.42^{\mathrm{a}}$ & $169.0 \pm 11.02^{\mathrm{ab}}$ & $0.34 \pm 0.06^{\mathrm{d}}$ & $1.41 \pm 0.18^{\mathrm{c}}$ \\
\hline $\begin{array}{c}40 \mu \mathrm{M} \\
\text { FeEDTA }\end{array}$ & NM & $20.7 \pm 2.98^{\text {bcdefghij }}$ & $60.1 \pm 0.93^{\mathrm{ac}}$ & $166.2 \pm 11.45^{\mathrm{abc}}$ & $0.35 \pm 0.10^{\mathrm{d}}$ & $1.32 \pm 0.31^{\mathrm{cd}}$ \\
\hline $\begin{array}{c}60 \mu \mathrm{M} \\
\text { FeEDTA }\end{array}$ & NM & $26.2 \pm 3.21^{\text {abcdefgh }}$ & $59.3 \pm 1.18^{\mathrm{a}}$ & $163.0 \pm 27.50^{\mathrm{abcd}}$ & $0.32 \pm 0.01^{\mathrm{d}}$ & $0.74 \pm 0.11^{\mathrm{d}}$ \\
\hline $\begin{array}{c}20 \mu \mathrm{M} \\
\text { FeEDDHA }\end{array}$ & NM & $34.6 \pm 4.59^{\mathrm{abcd}}$ & $71.6 \pm 9.96^{\mathrm{a}}$ & $174.8 \pm 10.31^{\mathrm{ab}}$ & $0.38 \pm 0.08^{d}$ & $1.21 \pm 0.30^{\mathrm{cd}}$ \\
\hline $\begin{array}{c}40 \mu \mathrm{M} \\
\text { FeEDDHA }\end{array}$ & NM & $29.2 \pm 4.30^{\text {abcdef }}$ & $46.8 \pm 1.85^{\mathrm{ab}}$ & $163.9 \pm 18.76^{\mathrm{abcd}}$ & $0.36 \pm 0.12^{d}$ & $1.19 \pm 0.10^{\mathrm{cd}}$ \\
\hline $\begin{array}{c}60 \mu \mathrm{M} \\
\text { FeEDDHA }\end{array}$ & NM & $23.8 \pm 4.60^{\text {bcdefghi }}$ & $61.0 \pm 2.86^{\mathrm{ac}}$ & $185.4 \pm 10.87^{\mathrm{a}}$ & $0.26 \pm 0.05^{\mathrm{d}}$ & $1.19 \pm 0.07^{\mathrm{cd}}$ \\
\hline
\end{tabular}

*Values followed by the same letter in each column are not significantly different at 0.05 . 
Table 5. Glomalin and a nonmycorrhizal glycoprotein concentration $(\mu \mathrm{g} / \mathrm{g})($ mean $\pm \mathrm{SE}) *$ for subsamples taken directly (i.e. without sieving) from within or outside of the mesh bag of mycorrhizal or nonmycorrhizal sudangrass treated with different concentrations of FeEDTA or FeEDDHA.

\begin{tabular}{|c|c|c|c|c|}
\hline $\begin{array}{c}\text { Mycorrhizal } \\
\text { status }\end{array}$ & \multicolumn{2}{|c|}{ Iron source* } & $\begin{array}{c}\text { Non-sieved sample from } \\
\text { within mesh bag }\end{array}$ & $\begin{array}{c}\text { Non-sieved sample from } \\
\text { outside mesh bag }\end{array}$ \\
\hline \multirow{7}{*}{ Myc } & \multicolumn{2}{|l|}{ No iron } & $910.4 \pm 358.50^{\mathrm{ab}}$ & $23.5 \pm 1.28^{\mathrm{a}}$ \\
\hline & \multirow{3}{*}{$\begin{array}{l}\text { FeEDTA } \\
\qquad(\mu \mathrm{M})\end{array}$} & 20 & $737.1 \pm 171.36^{\mathrm{ab}}$ & $19.2 \pm 1.77^{\mathrm{ab}}$ \\
\hline & & 40 & $873.0 \pm 264.25^{\mathrm{ab}}$ & $17.1 \pm 2.38^{\mathrm{b}}$ \\
\hline & & 60 & $1201.6 \pm 373.24^{\mathrm{a}}$ & $16.4 \pm 1.45^{\mathrm{b}}$ \\
\hline & \multirow{3}{*}{$\begin{array}{l}\text { FeEDDHA } \\
\qquad(\mu \mathrm{M})\end{array}$} & 20 & $533.8 \pm 11.63^{\mathrm{ab}}$ & $17.0 \pm 0.82^{\mathrm{b}}$ \\
\hline & & 40 & $555.3 \pm 107.30^{\mathrm{ab}}$ & $25.0 \pm 3.23^{\mathrm{a}}$ \\
\hline & & 60 & $883.7 \pm 377.48^{\mathrm{ab}}$ & $21.9 \pm 2.51^{\mathrm{ab}}$ \\
\hline \multirow{7}{*}{ NM } & \multicolumn{2}{|l|}{ No iron } & $456.3 \pm 56.66^{\mathrm{b}}$ & $5.6 \pm 0.67^{\mathrm{c}}$ \\
\hline & \multirow{3}{*}{$\begin{array}{l}\text { FeEDTA } \\
\qquad(\mu \mathrm{M})\end{array}$} & 20 & $497.7 \pm 36.36^{\mathrm{b}}$ & $4.9 \pm 0.15^{\mathrm{c}}$ \\
\hline & & 40 & $402.2 \pm 14.40^{\mathrm{b}}$ & $4.6 \pm 0.12^{\mathrm{cd}}$ \\
\hline & & 60 & $438.7 \pm 25.04^{b}$ & $5.0 \pm 0.46^{\mathrm{c}}$ \\
\hline & \multirow{3}{*}{$\begin{array}{l}\text { FeEDDHA } \\
\qquad(\mu \mathrm{M})\end{array}$} & 20 & $438.4 \pm 39.10^{\mathrm{b}}$ & $4.6 \pm 0.31^{\mathrm{cd}}$ \\
\hline & & 40 & $468.6 \pm 18.04^{b}$ & $4.5 \pm 0.09^{\mathrm{cd}}$ \\
\hline & & 60 & $420.5 \pm 41.27^{\mathrm{b}}$ & $3.8 \pm 0.30^{\mathrm{d}}$ \\
\hline
\end{tabular}

*Values followed by the same letter in each column are not significantly different at 0.05 . 
Table 6. Comparison of mycorrhizal to nonmycorrhizal sudangrass plants for foliar tissue analyses, percentage mycorrhizal colonization, sporulation, and protein measurements (means \pm $\mathrm{SE})^{*}$.

\begin{tabular}{|c|c|c|}
\hline & Mycorrhizal & Nonmycorrhizal \\
\hline Shoot dry weight (g) & $5.2 \pm 0.11^{\mathrm{a}}$ & $3.1 \pm 0.09^{\mathrm{b}}$ \\
\hline Percentage $\mathrm{P}$ & $0.044 \pm 0.001^{\mathrm{a}}$ & $0.040 \pm 0.0001^{\mathrm{b}}$ \\
\hline Percentage Fe & $0.008 \pm 0.000^{\mathrm{a}}$ & $0.012 \pm 0.001^{\mathrm{b}}$ \\
\hline Chl a $(\mu \mathrm{g} / \mathrm{g})$ & $1054.9 \pm 42.33^{\mathrm{a}}$ & $1283.6 \pm 78.73^{\mathrm{b}}$ \\
\hline $\mathrm{Chl} \mathrm{b}(\mu \mathrm{g} / \mathrm{g})$ & $241.4 \pm 9.89^{\mathrm{a}}$ & $294.3 \pm 20.66^{\mathrm{b}}$ \\
\hline \multicolumn{3}{|c|}{$\begin{array}{l}\text { Glomalin and nonmycorhizal glycoprotein concentration }(\mu \mathrm{g} / \mathrm{g}) \text { for samples from within } \\
\text { mesh bag }\end{array}$} \\
\hline Non-sieved sample & $823.1 \pm 103.52^{\mathrm{a}}$ & $451.8 \pm 13.31^{\mathrm{b}}$ \\
\hline $500 \mu \mathrm{m}$ sieve fraction (minus roots) & $17.1 \pm 0.92^{\mathrm{a}}$ & $26.1 \pm 1.57^{\mathrm{b}}$ \\
\hline $\begin{array}{l}150 \mu \mathrm{m} \text { sieve fraction (minus roots and fungal } \\
\text { material) }\end{array}$ & $57.4 \pm 4.37^{\mathrm{a}}$ & $62.3 \pm 2.58^{\mathrm{a}}$ \\
\hline $38 \mu \mathrm{m}$ sieve fraction (minus hyphae) & $126.7 \pm 8.61^{\mathrm{a}}$ & $163.8 \pm 6.05^{\mathrm{b}}$ \\
\hline Roots from $500 \mu \mathrm{m}$ sieve & $1691.1 \pm 420.66^{\mathrm{a}}$ & $16.4 \pm 1.44^{\mathrm{b}}$ \\
\hline Roots, hyphae, and spores from $150 \mu \mathrm{m}$ sieve & $297.2 \pm 50.98^{\mathrm{a}}$ & $374.0 \pm 26.36^{\mathrm{a}}$ \\
\hline \multicolumn{3}{|c|}{$\begin{array}{l}\text { Glomalin and nonmycorhizal glycoprotein concentration }(\mu \mathrm{g} / \mathrm{g}) \text { for samples from outside } \\
\text { mesh bag }\end{array}$} \\
\hline Non-sieved sample & $19.7 \pm 0.93^{\mathrm{a}}$ & $4.7 \pm 0.15^{\mathrm{b}}$ \\
\hline $500 \mu \mathrm{m}$ sieve fraction & $6.1 \pm 0.55^{\mathrm{a}}$ & $0.3 \pm 0.03^{\mathrm{b}}$ \\
\hline $38 \mu \mathrm{m}$ sieve fraction (minus hyphae) & $4.9 \pm 0.24^{\mathrm{a}}$ & $1.2 \pm 0.08^{\mathrm{b}}$ \\
\hline Hyphae from $38 \mu \mathrm{m}$ sieve & $63.0 \pm 5.53^{\mathrm{a}}$ & $63.2 \pm 7.60^{\mathrm{a}}$ \\
\hline
\end{tabular}

*Values followed by the same letter in each row are not significantly different at 0.05 

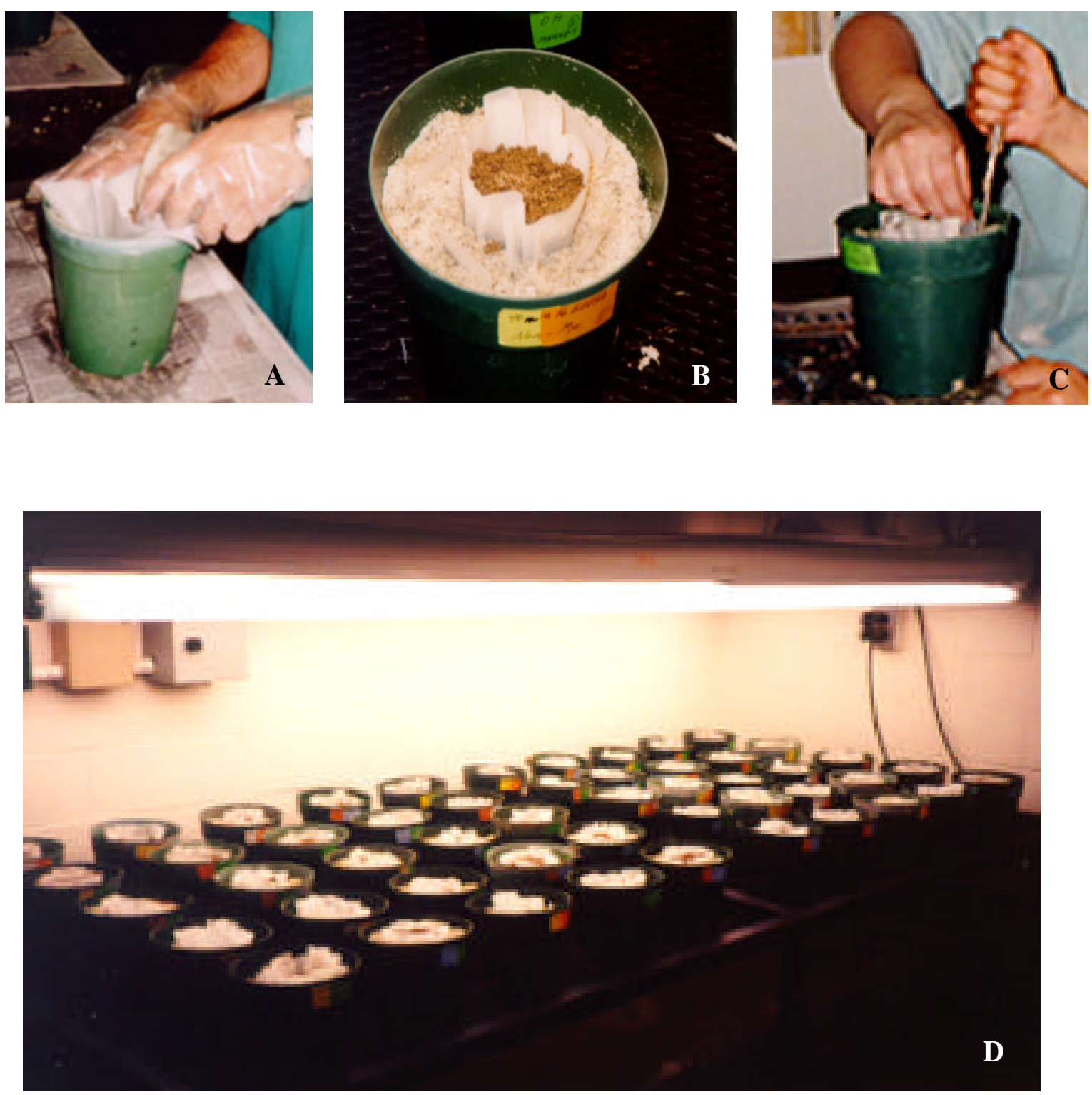

Figure 1. Stages in pot culture setup. (A) A seamless mesh bag with $45 \mu \mathrm{m}$ openings centered in 15-cm diam pots, (B) filled with a sand:soil mix and surrounded with sterile sand; (C) Mesh strips with $45 \mu \mathrm{m}$ openings inserted vertically midway between the mesh bag; (D) All pots randomly distributed on a growth room bench. 

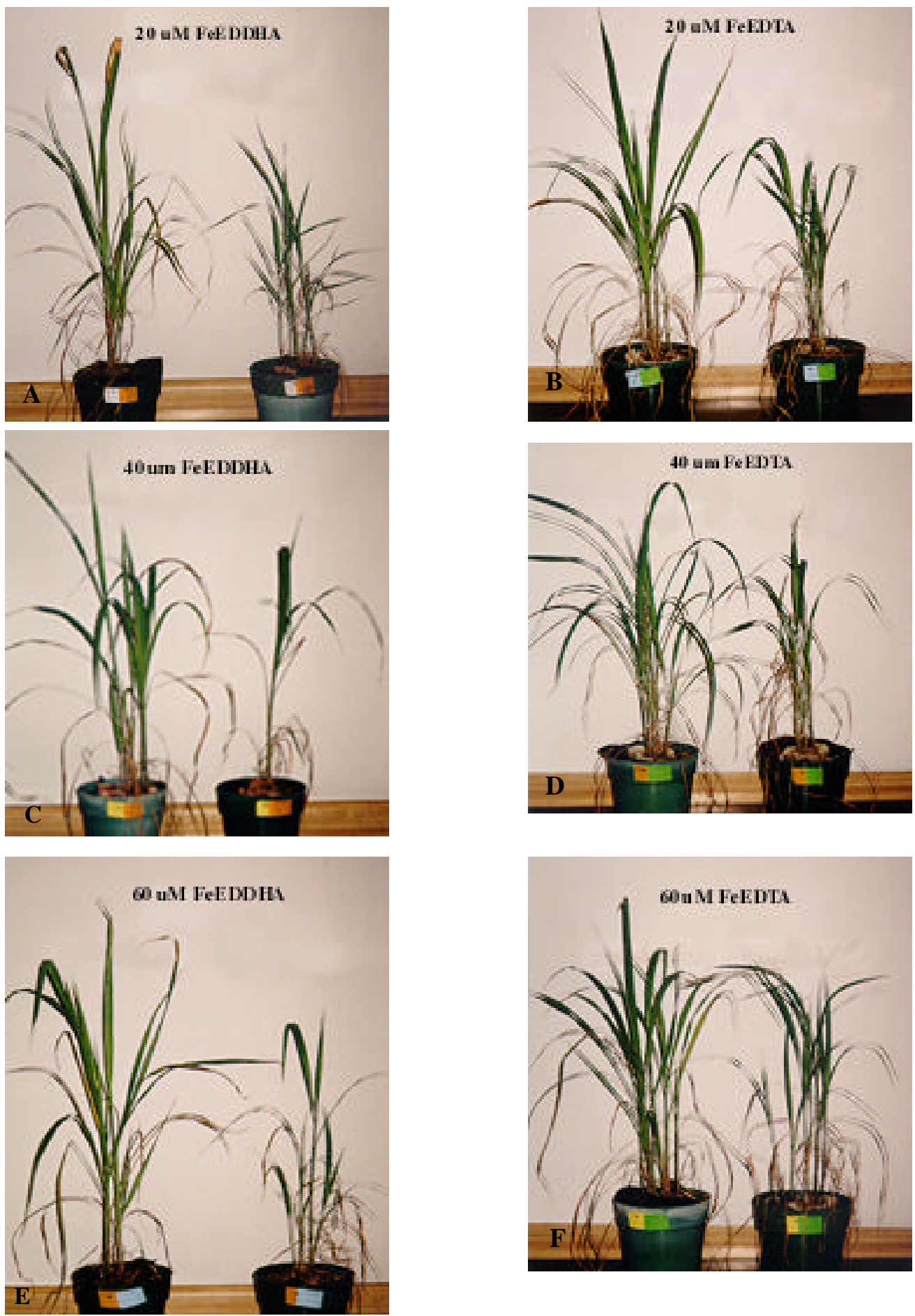

Figure 2. Comparisons between mycorrhizal (left) and nonmycorrhizal (right) sudangrass amended with (A) $20 \mu \mathrm{M}$ FeEDDA, (B) $20 \mu \mathrm{M}$ FeEDTA, (C) $40 \mu \mathrm{M}$ FeEDDHA, (D) $40 \mu \mathrm{M}$ FeEDTA, (E) $60 \mu \mathrm{M}$ FeEDDHA, and (F) 60 $\mu \mathrm{M}$ FeEDTA. 

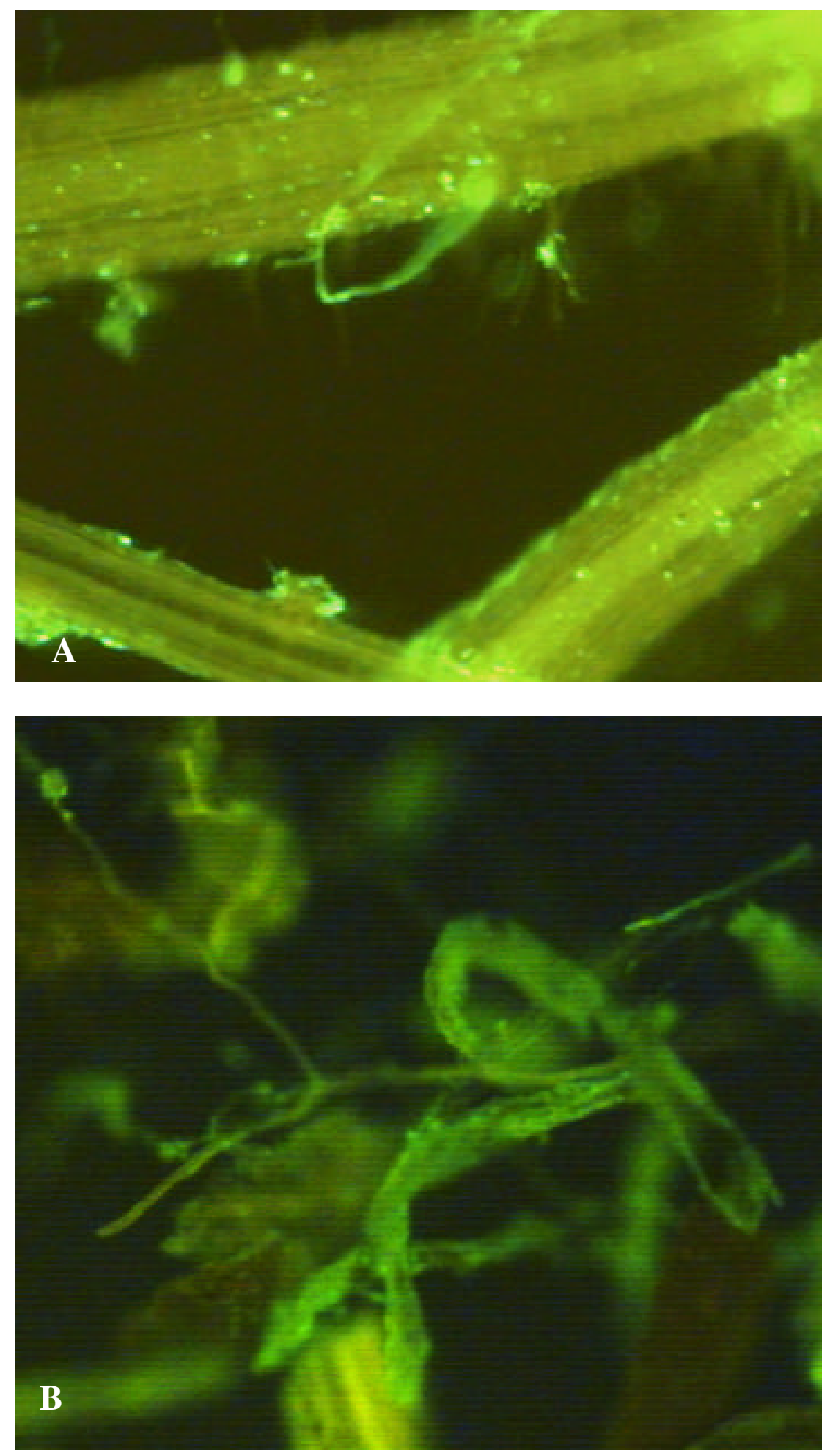

Figure 3. Patchy immunofluorescence of glomalin-like glycoprotein on nonmycorrhizal sudangrass roots. (A) close view, (B) distant view. 

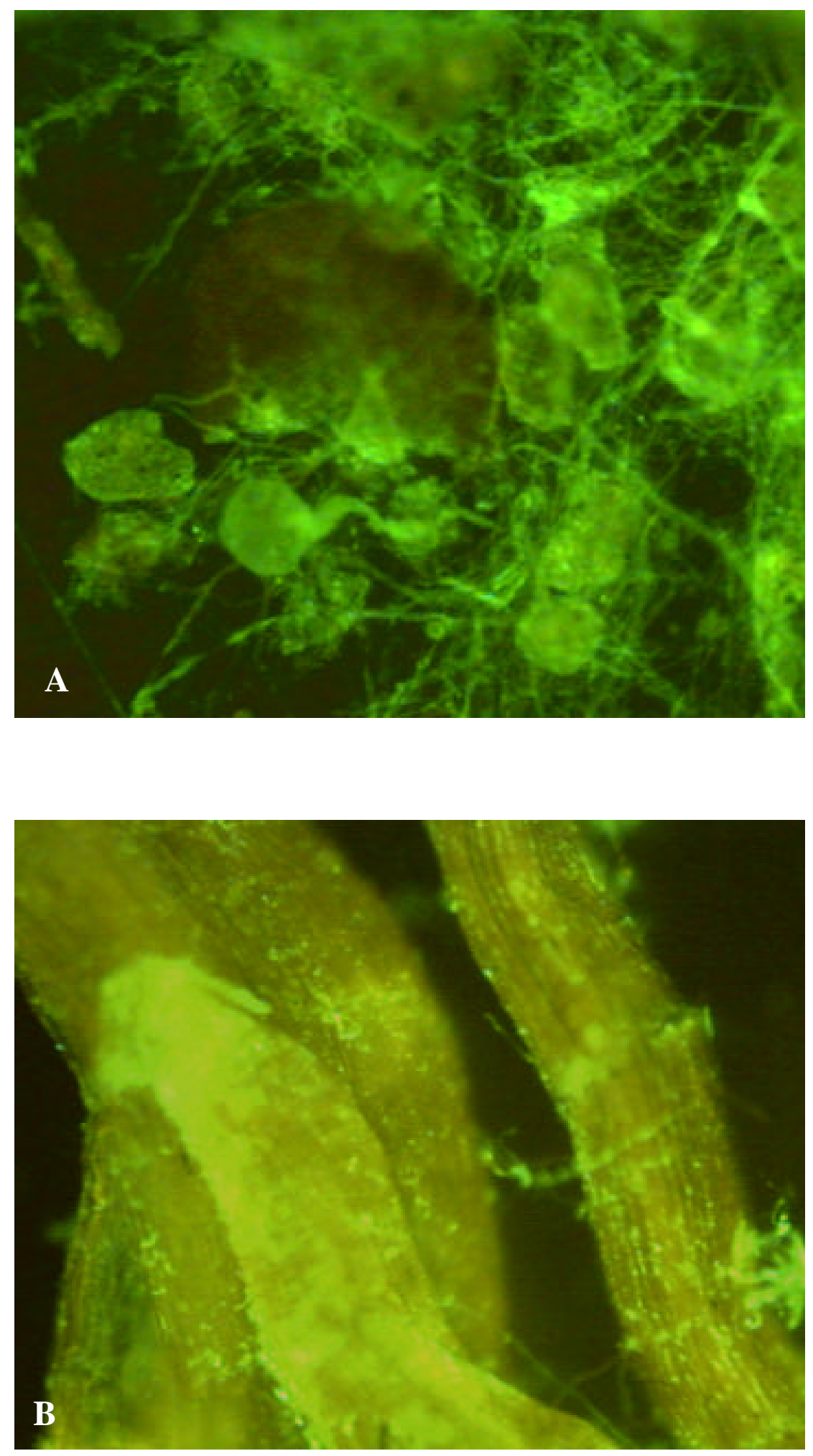

Figure 4. Immunofluorescent glomalin (A) selectively coating hyphae of Gigaspora gigantea; (B) patchily distributed on mycorrhizal sudangrass roots. 


\section{CONCLUSIONS}

Studies were carried out to determine the role of iron in production of a glycoprotein, glomalin, by symbiotic arbuscular mycorrhizal fungi. A preliminary pot culture experiment using an available, chelated iron source (FeEDDHA) and a highly unavailable, iron oxide (hematite) indicated that (1) conditions of the study resulted in an abnormally low glomalin concentrations (ng versus mg quantities); (2) a cross-reactive glycoprotein was being produced in nonmycorrhizal cultures at the same level as glomalin in mycorrhizal cultures; and (3) hematite completely inhibited mycorrhizal colonization. Because of these results, the effects of hematite on spore germination were measured in spore germination assays; the nonmycorrhizal glycoprotein was examined on different hosts and characterized to a limited extent biochemically; and effects of two chelated iron sources (FeEDTA and FeEDDHA) on glomalin production were reexamined.

Hematite clearly inhibited spore germination of arbuscular fungi used in the preliminary experiment (Gigaspora gigantea and Glomus etunicatum), differentially affecting the former fungus more than tha latter. In all assays, inhibition never was complete. Since mycorrhizal colonization was completely inhibited in the preliminary experiment, I hypothesize that hematite may create hydrophobic zones which changes the water potential critical for spore germination and coat roots to prevent initiation of mycorrhizal development from any surviving spore germ tubes.

Several tests proved that the cross-reactive glycoprotein produced in nonmycorrhizal cultures was not the result of contamination by mycorrhizal fungi. It and glomalin are both glycoproteins that bind to the monoclonal antibody clone 32B11 and react similar mannerly in immuno-dot blot assays. Banding patterns in SDS-PAGE gels show some similarities, but also unique bands as well. Both glycoproteins also contain iron, although that in the glomalin molecule is about 10 times the concentration of the nonmycorrhizal glycoprotein. The nonmycorrhizal glycoprotein is not host specific, forming by Sorghum bicolor and Festuca arundinacea. This glycoprotein is produced in very low concentrations, at least 10-fold less than that of glomalin in natural soils. It is hypothesized to be produced by the plant host under stressful conditions, such as low light intensity and/or low nutrients.

The effects of iron on glomalin production was revisited in an experiment using two chelated iron sources (FeEDDHA and FeEDTA) at three concentrations (20 $\mu \mathrm{M}, 40 \mu \mathrm{M}$, and 60 $\mu \mathrm{M})$ with sudangrass as host species. Glomalin concentrations were highest on the root fraction confined within a mesh bag and lowest in the sand medium (containing only fungal structures) outside the mesh bag. In many fractions, the concentration of nonmycorrhizal glycoprotein was equivalent to that of glomalin, although glomalin concentrations were atypically low. Iron source or concentration did not appear to have any significant and consistent effect on either glomalin or nonmycorrhizal glycoprotein concentration. Constraints on glomalin production in mycorrhizal roots with normal levels of colonization suggest that glomalin synthesis is affected by factors other than those impacting on mycorrhizal development.

All of the experiments conducted in this study raise more questions than provide answers, but they show that (i) any iron source, such as hematite, which constrains mycorrhizal 
development will impact on glomalin production, (ii) nonmycorrhizal plants subject to environmental stresses produce low levels of a glycoprotein that has some properties similar to glomalin, included binding by a specific monoclonal antibody, and (iii) chelated iron sources apparently do not impact appreciably on glomalin production. Future studies using different types of unavailable rather than available iron may help identify conditions necessary to increase glomalin production. Hematite was used as the unavailable source in the preliminary study, but this compound inferred with mycorrhizal colonization. The conditions of the early earth under which the mycorrhizal symbiosis evolved contained very little oxygen and iron was present in the sulfide and silicate forms, as opposed to the oxide form. Glomalin likely was synthesized by primitive mycorrhizal fungi in an environment with little oxygen and iron present in unavailable sulfide and silicate forms. More work is needed to identify location of iron in the glomalin molecule (e.g., if it's a heme protein), determine if glomalin is an iron chelator, and ascertain the mechanism of iron-binding. 
APPENDIX A

A PRELIMINARY STUDY TO DETERMINE THE RELATIONSHIP BETWEEN GLOMALIN PRODUCTION AND IRON AVAILABILITY 
Iron is an important component in the glomalin molecule and may be important in the ability of glomalin to aggregate soil particles and organic matter for nutrient acquisition. Because of this, unavailable, colloidal and available, chelated sources of iron were used to test their effects on mycorrhizal production and glomalin accumulation.

\section{MATERIALS AND METHODS}

1. $2: 1$ coarse:fine silica sand was acid washed with $2-3 \mathrm{~N} \mathrm{HCl}$ (testing showed that soaking sand in $2-3 \mathrm{~N} \mathrm{HCl}$ for 2 or more days, rinsing thoroughly with distilled water, adding 1.5-2.0 N $\mathrm{HCl}$ for another 2 or more day soak removed most of the iron), extracted for total protein with $50 \mathrm{mM}$ citrate, $\mathrm{pH} 8.0$, and autoclaved at $121^{\circ} \mathrm{C}$ for $90 \mathrm{~min}$

2. Hematite $\left(\mathrm{Fe}_{2} \mathrm{O}_{3}\right)$ was mixed $0.5 \%$ or $1.5 \%$ by weight with $1 / 3$ of the sand

3. A phosphate adsorption curve was run to determine if phosphorus deficiency would occur due to adsorption by hematite

4. Sterile 2:1 sand was placed in 6 standard \#6 pots and rinsed with alkaline ( $\mathrm{pH} \mathrm{8.0)} \mathrm{or} \mathrm{acidic}$ (pH 5.5) water.

5. $\sim 60$ Sorghum bicolor seeds were germinated in these pots

6. Gigaspora gigantea (MA453A) and Glomus etunicatum (NE108A) spores were extracted via water sieving and sucrose centrifugation

7. Debris and hyphal fragments were removed from the spore solution. Spores were sonicated for $15 \mathrm{~s}$ and rinsed with sterile water to remove further debris

8. Approximately 200 spores of one or the other species were applied onto the roots of three Sorghum bicolor seedlings with a sterile pipet and plants were placed in deepots ( 40 deepots/fungal species)

9. 40 deepots with the same media were also made and planted with non-inoculated Sorghum bicolor seedlings

10. The seedlings were planted in deepots containing sterile sand or sand mixed with $0.5 \%$ or $1.5 \%$ hematite

11. All pots were placed in the growth room and watered with $50 \mathrm{ml}$ of half strength Hoagland's nutrient solution with or without iron and at $\mathrm{pH} 5.5$ or 8.0, depending on the treatment

12. Four plastic horticulture mesh strips $10 \times 2 \mathrm{~cm}$ encircled the shoots midway between the plant and the deepot edge as traps for AM fungal hyphae

13. Because of iron chlorosis, $50 \mathrm{mls}$ of $25 \mu \mathrm{M}$ FeEDDHA amended nutrient solution was given to all of the pots that were receiving no Fe amended solution two to three times a week over a two week period

14. After the first five weeks, a piece of mesh was removed and extracted for total protein, with $50 \mathrm{mM}$ citrate, $\mathrm{pH} 8.0$, and autoclaving at $121^{\circ} \mathrm{C}$ for $60 \mathrm{~min}$

15. Both total protein and immunoreactive protein were quantified for the samples according to the Bradford total protein and ELISA assays

16. After 10 weeks, watering ceased 
17. A strip was removed and extracted for immunoreactive protein, which was quantified via the total and immunoreactive protein assays

18. Shoots were removed, dried at $70^{\circ} \mathrm{C}$, ground, digested with a microwave digestion procedure (Appendix E) and nitric acid, and were analyzed for $\mathrm{Fe}$ and $\mathrm{P}$ concentration

19. Roots were also removed for dry weight determination and percent root colonization

20. Residual root fragments were remixed with the potting media

21. The potting media was sampled for spores, using the wet sieving, sucrose centrifugation extraction method, and extracted immunoreactive protein

22. Total and immunoreactive protein was measured for each extract

\section{$\underline{\text { Results and Discussion }}$}

Both immunoreactive and total protein concentrations were very low for all of the treatments (Table 1). Technical problems with the assays and the harsh growing environment may account for some of the disparity in these results compared to mg concentration found in published research on glomalin. In some cases the protein concentrations for the nonmycorrhizal treatments were higher than those for the mycorrhizal treatments. In addition, the unavailable iron source (hematite) resulted in almost no protein, no spores, and no colonization (Tables 1 and 2).

The growing conditions for this experiment were harsh. The sand had been repeatedly acid-washed to remove residual iron and the light intensity was only about $12 \%$ of full sunlight. These constraints were reflected in the low shoot weights, especially with no or unavailable iron (Table 3). These shoots also exhibited signs of phosphate stress and iron chlorosis. However, in Table 4, the iron concentration was higher in the hematite treated plants, despite these plants being chlorotic and stressed for iron. Since hematite was a light powder, it could have blown onto the leaves, resulting in false readings.

The results show that: (1) glycoprotein is being produced in extremely low concentrations; (2) the hematite treatment is somehow inhibiting mycorrhizal growth by preventing either spore germination or root colonization; and (3) there may be something in the non-mycorrhizal treatments that is reacting with the monoclonal antibody against glomalin. 
Table 1. Total and immunoreactive glycoprotein $(\mu \mathrm{g} / \mathrm{g})$ in Sorghum bicolor pot cultures after 10 weeks

\begin{tabular}{|c|c|c|c|c|c|c|c|c|}
\hline \multirow{2}{*}{\multicolumn{3}{|c|}{ pH Iron Source }} & \multicolumn{3}{|c|}{ Total Glycoprotein $(\mu \mathrm{g} / \mathrm{g})$} & \multicolumn{3}{|c|}{$\begin{array}{l}\text { Immunoreactive glycoprotein } \\
(\mu \mathrm{g} / \mathrm{g})\end{array}$} \\
\hline & & & $\begin{array}{c}\text { Gi. } \\
\text { gigantea }\end{array}$ & $\begin{array}{c}G . \\
\text { etunicatum }\end{array}$ & Nonmyc & $\begin{array}{c}\text { Gi. } \\
\text { gigantea }\end{array}$ & $\begin{array}{c}\text { G. } \\
\text { etunicatum }\end{array}$ & Nonmyc \\
\hline \multirow{5}{*}{5.5} & \multirow{2}{*}{ FeEDDHA } & $25 \mu \mathrm{M}$ & 39.50 & 39.55 & 49.68 & 0.00 & 2.44 & 0.00 \\
\hline & & $50 \mu \mathrm{M}$ & 57.76 & 36.78 & 33.09 & 0.00 & 1.98 & 0.00 \\
\hline & \multirow{2}{*}{ Hematite } & $0.50 \%$ & 31.88 & 35.96 & 30.67 & 0.00 & 0.00 & 0.00 \\
\hline & & $1.50 \%$ & 38.07 & 25.38 & 53.62 & 0.00 & 0.00 & 0.00 \\
\hline & No iron & 0.00 & 49.40 & 35.16 & 20.72 & 0.00 & 2.27 & 0.00 \\
\hline \multirow{5}{*}{8} & \multirow{2}{*}{ FeEDDHA } & $25 \mu \mathrm{M}$ & 40.58 & 56.31 & 27.76 & 0.00 & 7.29 & 2.09 \\
\hline & & $50 \mu \mathrm{M}$ & 46.32 & 39.86 & 22.34 & 0.92 & 3.72 & 0.07 \\
\hline & \multirow{2}{*}{ Hematite } & $0.50 \%$ & 50.71 & 30.90 & 16.02 & 0.00 & 0.00 & 0.00 \\
\hline & & $1.50 \%$ & 40.80 & 36.95 & 19.74 & 0.00 & 0.00 & 0.00 \\
\hline & No iron & 0.00 & 55.69 & 41.39 & 17.00 & 0.00 & 1.11 & 0.00 \\
\hline
\end{tabular}

Table 2. Percentage root colonization and spore density in $50 \mathrm{~cm}^{3}$ in Sorghum bicolor pot cultures after 10 weeks

\begin{tabular}{|c|c|c|c|c|c|c|c|c|}
\hline \multirow{2}{*}{$\mathrm{pH}$} & \multirow{2}{*}{\multicolumn{2}{|c|}{ Iron Source }} & \multicolumn{3}{|c|}{ Percentage colonization } & \multicolumn{3}{|c|}{ Spore density } \\
\hline & & & $\begin{array}{c}\text { Gi. } \\
\text { gigantea }\end{array}$ & $\begin{array}{c}G . \\
\text { etunicatum }\end{array}$ & Nonmyc & $\begin{array}{c}\text { Gi. } \\
\text { gigantea }\end{array}$ & $\begin{array}{c}G . \\
\text { etunicatum }\end{array}$ & Nonmyc \\
\hline \multirow{5}{*}{5.5} & \multirow{2}{*}{ FeEDDHA } & $25 \mu \mathrm{M}$ & 34 & 42 & 0 & 100 & 7470 & 0 \\
\hline & & $50 \mu \mathrm{M}$ & 15 & 37 & 0 & 56 & 11689 & 0 \\
\hline & \multirow{2}{*}{ Hematite } & $0.50 \%$ & 0 & 0 & 0 & 2 & 2 & 0 \\
\hline & & $1.50 \%$ & 0 & 0 & 0 & 3 & 6 & 0 \\
\hline & No iron & 0.00 & 11 & 14 & 0 & 33 & 1202 & 0 \\
\hline \multirow{5}{*}{8} & \multirow{2}{*}{ FeEDDHA } & $25 \mu \mathrm{M}$ & 8 & 29 & 0 & 2 & 5106 & 0 \\
\hline & & $50 \mu \mathrm{M}$ & 16 & 29 & 0 & 35 & 4096 & 0 \\
\hline & \multirow{2}{*}{ Hematite } & $0.50 \%$ & 0 & 0 & 0 & 0 & 1 & 0 \\
\hline & & $1.50 \%$ & 0 & 0 & 0 & 1 & 0 & 0 \\
\hline & No iron & 0.00 & 14 & 11 & 0 & 16 & 165 & 0 \\
\hline
\end{tabular}


Table 3. Shoot dry weight of Sorghum bicolor shoots (g)

\begin{tabular}{|c|c|c|c|c|c|}
\hline \multirow{2}{*}{\multicolumn{3}{|c|}{$\mathrm{pH} \quad$ Iron Source }} & \multicolumn{3}{|c|}{ Shoot dry weight $(\mathrm{g})$} \\
\hline & & & \multirow{2}{*}{$\begin{array}{c}\text { Gi. gigantea } \\
1.71\end{array}$} & \multirow{2}{*}{$\begin{array}{c}\text { G. etunicatum } \\
2.11\end{array}$} & \multirow{2}{*}{$\begin{array}{c}\text { Nonmyc } \\
1.56\end{array}$} \\
\hline \multirow{5}{*}{5.5} & \multirow{2}{*}{ FeEDDHA } & $25 \mu \mathrm{M}$ & & & \\
\hline & & $50 \mu \mathrm{M}$ & 2.16 & 2.19 & 2.34 \\
\hline & \multirow{2}{*}{ Hematite } & $0.50 \%$ & 1.57 & 1.53 & 1.39 \\
\hline & & $1.50 \%$ & 1.41 & 0.83 & 0.75 \\
\hline & No iron & 0.00 & 1.37 & 1.16 & 1.27 \\
\hline \multirow{5}{*}{8} & \multirow{2}{*}{ FeEDDHA } & $25 \mu \mathrm{M}$ & 1.49 & 1.33 & 1.20 \\
\hline & & $50 \mu \mathrm{M}$ & 1.66 & 1.49 & 1.44 \\
\hline & \multirow{2}{*}{ Hematite } & $0.50 \%$ & 0.87 & 0.83 & 0.82 \\
\hline & & $1.50 \%$ & 0.97 & 0.58 & 0.51 \\
\hline & No iron & 0.00 & 0.69 & 0.91 & 0.43 \\
\hline
\end{tabular}

Table 4. Percentage $P$ and Fe in Sorghum bicolor shoots after 10 weeks

\begin{tabular}{|c|c|c|c|c|c|c|c|c|}
\hline \multirow{2}{*}{\multicolumn{3}{|c|}{$\mathrm{pH} \quad$ Iron Source }} & \multicolumn{3}{|c|}{$\% \mathrm{P}$} & \multicolumn{3}{|c|}{$\% \mathrm{Fe}$} \\
\hline & & & \multirow{2}{*}{$\begin{array}{c}\text { Gi. } \\
\text { gigantea } \\
0.09\end{array}$} & \multirow{2}{*}{$\begin{array}{c}\begin{array}{c}G . \\
\text { etunicatum }\end{array} \\
0.07\end{array}$} & \multirow{2}{*}{$\begin{array}{c}\text { Nonmyc } \\
0.08\end{array}$} & \multirow{2}{*}{$\begin{array}{c}\text { Gi. } \\
\text { gigantea }\end{array}$} & \multirow{2}{*}{\begin{tabular}{|c|}
$\begin{array}{c}G . \\
\text { etunicatum }\end{array}$ \\
0.001 \\
\end{tabular}} & \multirow{2}{*}{\begin{tabular}{|c|} 
Nonmyc \\
0.001 \\
\end{tabular}} \\
\hline \multirow{5}{*}{5.5} & \multirow{2}{*}{ FeEDDHA } & $25 \mu \mathrm{M}$ & & & & & & \\
\hline & & $50 \mu \mathrm{M}$ & 0.06 & 0.08 & 0.06 & 0.001 & 0.002 & 0.002 \\
\hline & \multirow{2}{*}{ Hematite } & $0.50 \%$ & 0.08 & 0.08 & 0.07 & 0.002 & 0.003 & 0.005 \\
\hline & & $1.50 \%$ & 0.07 & 0.07 & 0.09 & 0.004 & 0.006 & 0.005 \\
\hline & No iron & 0.00 & 0.09 & 0.11 & 0.07 & 0.001 & 0.001 & 0.001 \\
\hline \multirow{5}{*}{8} & \multirow{2}{*}{ FeEDDHA } & $25 \mu \mathrm{M}$ & 0.07 & 0.11 & 0.08 & 0.003 & 0.003 & 0.003 \\
\hline & & $50 \mu \mathrm{M}$ & 0.08 & 0.09 & 0.07 & 0.002 & 0.002 & 0.001 \\
\hline & \multirow{2}{*}{ Hematite } & $0.50 \%$ & 0.12 & 0.10 & 0.09 & 0.004 & 0.003 & 0.006 \\
\hline & & $1.50 \%$ & 0.08 & 0.08 & 0.08 & 0.005 & 0.006 & 0.005 \\
\hline & No iron & 0.00 & 0.17 & 0.11 & 0.15 & 0.001 & 0.001 & 0.002 \\
\hline
\end{tabular}




\section{APPENDIX B}

\section{HALF-STRENGTH HOAGLAND'S NUTRIENT SOLUTION}


Half-strength Hoagland's solution contains nutrients for plant growth at the concentrations outlined in the table below. An MES buffer was added to all of the solutions to buffer the $\mathrm{pH}$ at 5.5, 6.2, or 8.0 depending on the experiment. The iron type and concentration varied depending on the treatment with only one type and concentration of iron per pot at a time.

\begin{tabular}{|c|c|}
\hline Nutrient & $\begin{array}{c}\text { Concentration } \\
(\mathbf{m M})\end{array}$ \\
\hline $\mathrm{Ca}\left(\mathrm{NO}_{3}\right)_{2} * 4 \mathrm{H}_{2} \mathrm{O}$ & 2.5 \\
\hline $\mathrm{KNO}_{3}$ & 2.5 \\
\hline $\mathrm{MgSO}_{4} * 7 \mathrm{H}_{2} \mathrm{O}$ & 1.0 \\
\hline $\mathrm{KH}_{2} \mathrm{PO}_{4}$ & 0.02 \\
\hline $\mathrm{H}_{3} \mathrm{BO}_{4}$ & 0.01 \\
\hline $\mathrm{Na}_{2} \mathrm{MoO}_{4} * 2 \mathrm{H}_{2} \mathrm{O}$ & 0.0002 \\
\hline $\mathrm{MnCl}_{2} * 4 \mathrm{H}_{2} \mathrm{O}$ & 0.002 \\
\hline $\mathrm{CoCl}_{2} * 2 \mathrm{H}_{2} \mathrm{O}$ & 0.0002 \\
\hline $\mathrm{ZnSO} 4 * 7 \mathrm{H}_{2} \mathrm{O}$ & 0.001 \\
\hline $\mathrm{CuSO}_{4}$ & 0.0005 \\
\hline $\mathrm{NiSO}_{4} * 6 \mathrm{H}_{2} \mathrm{O}$ & 0.0002 \\
\hline $20 \mathrm{uM} \mathrm{FeEDDHA}$ & 0.02 \\
\hline $40 \mu \mathrm{M} \mathrm{FeEDDHA}$ & 0.04 \\
\hline $60 \mu \mathrm{M} \mathrm{FeEDDHA}$ & 0.06 \\
\hline $20 \mu \mathrm{M}$ FeEDTA & 0.02 \\
\hline $40 \mu \mathrm{M}$ FeEDTA & 0.04 \\
\hline $60 \mu \mathrm{M}$ FeEDTA & 0.06 \\
\hline
\end{tabular}


APPENDIX C

GLYCOPROTEIN CARBOHYDRATE ESTIMATION METHOD 
Materials Needed

Sodium meta-periodate

Aldehyde Detection Reagent

Glycoprotein Assay buffer

$1 \mathrm{~N} \mathrm{NaOH}$

Eppendorf tubes

Cuvettes

Spectrophotometer

Lyophilized Protein Standards

A. Negative controls: Lysozyme and Bovine serum albumin

B. Positive controls: Ovalbumin, Human Apotransferrin, Fetuin, and $\alpha_{1}$-Acid glycoprotein

\section{Methods}

1. Allow chemicals warm to room temperature

2. Prepare a $10 \mathrm{mM}$ solution of sodium meta-periodate in Glycoprotein Assay Buffer and a $0.5 \%$ solution of Aldehyde Detection Reagent in $1 \mathrm{~N} \mathrm{NaOH}$

3. Reconstitute $\sim 0.25 \mathrm{~g}$ of lyophilized samples and the lyophilized standards in $1 \mathrm{ml}$ of Glycoprotein Assay Buffer

4. Place $0.2 \mathrm{ml}$ of each standard and sample in an Eppendorf tube

5. Add $0.1 \mathrm{ml}$ of $10 \mathrm{mM}$ sodium meta-periodate, vortex, and incubate at room temperature for $10 \mathrm{~min}$

6. Add $0.3 \mathrm{ml}$ of $0.5 \%$ Aldehyde Detection Reagent, vortex, and incubate $1 \mathrm{hr}$ at room temperature

7. Read at $550 \mathrm{~nm}$ with spectrophotometer

8. Plot a standard curve and compare samples to this standard curve 


\section{APPENDIX D}

SILVER STAINING OF SDS-PAGE GEL WITH THE PHASTSYSTEM 
After the separation program was complete, the gel was removed and developed with a modified PhastSystem ${ }^{\mathrm{TM}}$ File No. 210 silver stain procedure. The procedure was as follows.

\section{$\underline{\text { Materials }}$}

Staining box

$50 \%$ ethanol (v/v)/10\% acetic acid (v/v) solution

glutaraldehyde $(8.3 \%)(\mathrm{v} / \mathrm{v})$ solution

$0.25 \%$ silver nitrate $(\mathrm{w} / \mathrm{v})$ solution

$0.015 \%$ formaldhyde $(\mathrm{v} / \mathrm{v}) / 2.5 \%$ sodium carbonate $(\mathrm{w} / \mathrm{v})$ solution

Deionized water

$5 \%$ acetic acid $(\mathrm{v} / \mathrm{v})$ solution

$10 \%$ acetic acid (v/v)/5\% glycerol (v/v) solution

\section{Methods}

1. Pre-treatment with a $50 \%$ ethanol (v/v)/10\% acetic acid (v/v) solution for $2 \mathrm{~min}$

2. Incubation in a dilute glutaraldehyde (8.3\%) (v/v) solution for $15 \mathrm{~min}$

3. Rinsing with water for two 2-min intervals

4. Immersion in $0.25 \%$ silver nitrate $(\mathrm{w} / \mathrm{v})$ for $13 \mathrm{~min}$

5. Rinsing again with water for two 0.5 -min periods

6. Development with a $0.015 \%$ formaldhyde $(\mathrm{v} / \mathrm{v}) / 2.5 \%$ sodium carbonate $(\mathrm{w} / \mathrm{v})$ solution for 4 $\min$

7. Stain was set with an incubation in $5 \%$ acetic acid (v/v) solution for $2 \mathrm{~min}$ and followed by 3 $\mathrm{min}$ in $10 \%$ acetic acid (v/v)/5\% glycerol (v/v) solution 


\section{APPENDIX E}

\section{MICROWAVE PROGRAM FOR FOLIAR TISSUE DIGESTION}


1. Place teflon tubes with tissue sample, nitric acid, and hydrogen peroxide in microwave

2. Make sure there is water in the transducer by injecting it with a syringe

3. Attach pressure transducer to control top

4. Start program

$\begin{array}{cccc}\text { Stage } & 1 & 2 & 3 \\ \text { Power } & 75 & 100 & 100 \\ \text { PSI } & 050 & 060 & 075 \\ \text { Time } & 2000 & 2000 & 4000 \\ \begin{array}{c}\text { TAP (time at } \\ \text { pressure) }\end{array} & 0300 & 0300 & 1500 \\ \text { Temp } & 0 & 0 & 0\end{array}$

5. Remove tubes from microwave after pressure drops to less than $25 \mathrm{psi}$ 


\author{
Kristine Nichols \\ 9308 Cherry Hill Rd \#613 \\ College Park, MD 20740 \\ krnichol@asrr.arsusda.gov \\ (301) 477-1782, (301) 504-6977
}

\title{
EDUCATION
}

1999-present Ph.D., Agronomy, College of Natural Resouces, University of Maryland

1996-1999 M.S., Environmental Microbiology, Division of Plant and Soil Sciences, West Virginia University

1990-1995 B.S., Plant Biology, College of Biological Sciences, University of Minnesota

1990-1995 B.S., Genetics and Cell Biology, College of Biological Sciences, University of Minnesota

\section{EXPERIENCE}

Jan., 1999-Present

\section{Research Associate}

Center for Agriculture Biotechnology, University of Maryland

*Working with Dr. Sara Wright at USDA-ARS-SMSL

*Role of glomalin in soil structure and plant health

June, 1996-Dec., 1998 Graduate Research Assistant

Division of Plant and Soil Sciences, West Virginia University

*Role of iron in glomalin accumulation

*Effects of iron availability and/or concentration on glomalin accumulation and spore germination.

May, 1995-June, 1996 Senior Laboratory Technician

Department of Plant Biology, University of Minnesota

*Role of arbuscular mycorrhizal fungi (AMF) in prairie and wetland reclamation

*Arbuscular mycorrhizal inoculum generation comparing three growing conditions treatments

June, 1994-May, 1995 Undergraduate Research Assistant

Department of Plant Biology, University of Minnesota

*Arbuscular mycorrhizal generation in pot culture for reclamation.

*Field sampling and soil collection for mycorrhizal characterization.

Jan., 1994-May, 1994 Directed Research Student

Department of Plant Biology, University of Minnesota

*Growth study on Lythrum salicaria, purple loosestrife

*Arbuscular mycorrhizal spore extraction from field samples and pot cultures 


\section{RESEARCH PRESENTATIONS}

Oct, 1998 Poster-Effects of Iron Availability on Spore Germination of Arbuscular Mycorrhizal Fungi, Agronomy Society Meeting, Baltimore, MD.

\section{PROFESSIONAL EXPERIENCE}

Instructor, Workshop on Taxonomy of Endomycorrhizal Fungi. ICOM I (International Conference on Mycorrhizae), Berkeley, CA - USA. August, 1996

TEACHING EXPERIENCE

1997, 1998 Teaching Assistant, Plant Pathology Laboratory, Division of Plant and Soil Sciences, West Virginia University

\section{HONORS AND AWARDS}

Eloise Pittman Scholarship for Excellence in Plant Biology, University of Minnesota, June, 1994

President's Leadership and Service Award, University of Minnesota, October, 1995

\section{SOCIETAL AFFILIATIONS}

Mycological Society of America

Soil Science Society of America 